\title{
VARIAÇÃO DA CAPACIDADE DE CARGA COM A SUCÇÃO E PROFUNDIDADE EM ENSAIOS DE PLACA EM SOLO COLAPSÍVEL
}

Marcos Fernando Macacari

Dissertação apresentada à Escola de Engenharia de São Carlos da Universidade de São Paulo, como parte dos requisitos para obtenção do título de Mestre em Geotecnia

ORIENTADOR: Prof. Dr. José Carlos Ângelo Cintra

São Carlos

2001 


\section{DEDICATÓRIA}

Aos meus pais José Reinaldo e Joana

a minha esposa, Luci

a minha filha, Beatriz

a meu filho, Pedro 


\section{AGRADECIMENTOS}

Ao Prof. José Carlos A. Cintra pela orientação, amizade e confiança em mim depositada durante o desenvolvimento do presente trabalho.

Aos amigos Mauro Menegotto, Tulia Ribeiro dos Santos, Yuri Jatobá Costa pelo apoio no desenvolvimento da execução das provas de carga.

Ao Prof. Nelson Aoki pela colaboração e amizade.

Ao Departamento de Engenharia Civil da UNESP/Bauru, em especial ao Prof. Dr. Cláudio Vidrih Ferreira, pelo empréstimo da torre de transferência de carga.

A todos os colegas, professores e funcionários do Departamento de Geotecnia da USP/São Carlos o meu muito obrigado pela amizade ao longo do desenvolvimento deste trabalho. 


\section{SUMÁRIO}

LISTA DE FIGURAS $\quad$ i

LISTA DE TABELAS

LISTA DE FOTOS vi

LISTA DE ABREVIATURAS E SIGLAS vii

LISTA DE SÍMBOLOS viii

RESUMO ix

ABSTRACT $\quad x$

1. INTRODUÇÃO 01

2. REVISÃO BIBLIOGRÁFICA 03

2.1. Solos colapsíveis 03

2.1.1. Ocorrência de solos colapsíveis 05

2.2. Prova de carga em placa 07

$\begin{array}{ll}\text { 2.3. Tipos de ensaio } & 10\end{array}$

2.3.1. Ensaio rápido (Quick maintained load test - QML) 10

2.3.2. Ensaio lento (Slow maintained load test - SML) 11

2.3.3. Ensaio misto (Mixed maintained load test - MML) 11

2.4. Influência da forma da placa na capacidade de carga 14

2.5. Influência da dimensão da placa nos recalques medidos 15

$\begin{array}{ll}\text { 2.6. Capacidade de carga } & 16\end{array}$

3. GEOLOGIA LOCAL 20

3.1. Caracterização geotécnica 21

3.1.1. Ensaios in situ 21

3.1.2. Ensaios de laboratório $\quad 24$

3.2. Variabilidade do maciço de solos 26

4. MATERIAIS E MÉTODOS 30

4.1. Provas de carga em placa 30

4.2. Equipamentos e materiais $\quad 32$ 
$\begin{array}{ll}\text { 4.3. Sistema de reação } & 38\end{array}$

4.4. Medidas de sucção e teor de umidade $\quad 40$

5. APRESENTAÇÃO DOS RESULTADOS 41

5.1. Sucção matricial 41

5.2. Teor de umidade $\quad 42$

5.3. Curvas tensão x recalque 44

6. ANÁLISE DOS DADOS 47

6.1. Relação entre a sucção matricial e o teor de umidade 47

6.2. Tensão de ruptura 48

6.3. Influência da sucção e da profundidade $\quad 54$

6.4. Comparação com ensaios de compressão confinada 57

6.5. Redução da tensão de ruptura devido ao colapso 59

6.6. Curva característica de sucção do solo 61

7. CONCLUSÕES E SUGESTÕES PARA FUTURAS PESQUISAS 64

7.1. Conclusões 64

7.2. Sugestões para futuras pesquisas $\quad 65$

8. BIBLIOGRAFIA 66

APÊNDICE A - Calibração da célula de carga de 200 kN 70

APÊNDICE B - Calibração da célula de carga de 500 kN 71

APÊNDICE C - Tensão de ruptura obtida utilizando o critério de $25 \mathrm{~mm}$ e o de Pacheco Silva (1970) com o correspondente recalque $\quad 72$

$\begin{array}{ll}\text { APÊNDICE D - Planilhas das provas de carga } & 73\end{array}$

APÊNDICE E - Planilhas do teor de umidade $\quad 88$

APÊNDICE F - Regressão múltipla linear para o critério de ruptura de $25 \mathrm{~mm} \quad 95$

APÊNDICE G - Regressão múltipla linear para o critério de ruptura de Pacheco Silva (1970) 96 


\section{LISTA DE FIGURAS}

FIGURA 2.1 - Ocorrência de colapso em prova de carga realizada com inundação do solo durante o ensaio (CINTRA, 1998)

FIGURA 2.2 - Conceito básico de recalque adicional devido ao colapso da estrutura do solo (JENNINGS \& KNIGHT (1975) apud CINTRA, 1998)

FIGURA 2.3 - Prova de carga em solo colapsível previamente inundado (CINTRA, 1998)

FIGURA 2.4 - Solos colapsíveis estudados no Brasil (FERREIRA et al., 1989 apud CINTRA, 1998)

FIGURA 2.5 - Distribuição dos depósitos de cobertura cenozóica no interior do Estado de São Paulo (FULFARO \& BJORNBERG (1993) apud CINTRA, 1998).

FIGURA 2.6 - Curva tensão x recalque para a profundidade $1,0 \mathrm{~m}$.

FIGURA 2.7 - Curva tensão x recalque para a profundidade $5,0 \mathrm{~m}$.

FIGURA 2.8 - Curva tensão x recalque para a profundidade $7,0 \mathrm{~m}$.

FIGURA 2.9 - Curva pressão x recalque para a profundidade de 1,0 e 2,0 m (não inundado).

FIGURA 2.10 - Curva pressão x recalque para a profundidade de 1,0 e $2,0 \mathrm{~m}$ (inundado), comparada a de um ensaio não inundado.

FIGURA 2.11 - Curvas tensão x recalque dos ensaios MML inundados (COSTA, 1999).

FIGURA 2.12 - Comparação entre os ensaios SML, QML e MML (COSTA, 1999).

FIGURA 2.13 - Influência da forma da placa na carga de ruptura (FREIBERG, 1931 apud MASSAD, 1985)

FIGURA 2.14 - Relação entre recalque e o diâmetro da placa (VARGAS, 1978 apud COSTA, 1999) 
FIGURA 2.15 - Variação da tensão de ruptura de sapatas corridas em função da sucção matricial (FREDLUND \& RAHARDJO, 1993)

FIGURA 2.16 - Curvas tensão x recalque dos ensaios SML (COSTA, 1999).

FIGURA 2.17 -Curvas tensão x recalque dos ensaios QML (COSTA, 1999).

FIGURA 2.18 - Variação da tensão de ruptura com a sucção matricial (COSTA, 1999).

FIGURA 3.1 - Seção esquemática da geologia de pequena profundidade em São Carlos (CINTRA et al., 1991).

FIGURA 3.2 - Perfil do terreno associado às sondagens à percussão (SANTOS, 2001).

FIGURA 3.3 - Variação do $\mathrm{N}_{\mathrm{SPT}}$ médio em função da profundidade para cada campanha de sondagem realizada (SANTOS, 2001).

FIGURA 3.4 - Variação das resistências unitárias (qc e fs) em função da profundidade para cada campanha de sondagem realizada (SANTOS, 2001).

FIGURA 3.5 - Curvas granulométricas obtidas para as profundidades de 3, 5 e $8 \mathrm{~m}$ (MACHADO, 1998).

FIGURA 3.6 - Variabilidade do maciço de solos em função do $\mathrm{N}_{\mathrm{SPT}}$ e litologia para a $1^{\circ}$ campanha de sondagem à percussão (SANTOS, 2001).

FIGURA 3.7 - Variabilidade do maciço de solos em função do $\mathrm{N}_{\mathrm{SPT}}$ e litologia para a $2^{\circ}$ campanha de sondagem à percussão (SANTOS, 2001).

FIGURA 3.8 - Variabilidade do maciço de solos em função do $\mathrm{N}_{\mathrm{SPT}}$ e litologia para a $3^{\circ}$ campanha de sondagem à percussão (SANTOS, 2001).

FIGURA 4.1 - Locação das cavas para os ensaios de placa.

FIGURA 4.2 - Esquema de montagem das provas de carga.

FIGURA 5.1 - Variação da sucção com a profundidade. 
FIGURA 5.2 - Variação do teor de umidade com a profundidade.

FIGURA 5.3 - Curva tensão x recalque para profundidade $1,50 \mathrm{~m}$.

FIGURA 5.4 - Curvas tensão x recalque para profundidade $4,0 \mathrm{~m}$.

FIGURA 5.5 - Curvas tensão x recalque para profundidade $6,0 \mathrm{~m}$.

FIGURA 5.6 - Curvas tensão x recalque para profundidade $8,0 \mathrm{~m}$.

FIGURA 6.1 - Sucção matricial x teor de umidade, associados a profundidade do ensaio.

FIGURA 6.2 - Profundidade x tensão para o recalque de $25 \mathrm{~mm}$ (ensaios não inundados)

FIGURA 6.3 - Profundidade x tensão para o recalque de $25 \mathrm{~mm}$ (ensaios inundados)

FIGURA 6.4 - Curva tensão $\mathrm{x}$ recalque (escala monologarítmica).

FIGURA 6.5 - Profundidade x $\sigma r$ (ensaios não inundados)

FIGURA 6.6 - Profundidade x $\sigma r$ (ensaios inundados)

FIGURA 6.7 - Profundidade x $\rho r$ - ensaios não inundados.

FIGURA 6.8 - Profundidade x $\rho r$ - ensaios inundados.

FIGURA 6.9 - Tensão de ruptura para recalque de $25 \mathrm{~mm} \mathrm{x}$ sucção x profundidade.

FIGURA 6.10 - Tensão de ruptura de Pacheco Silva (1970) x sucção x profundidade.

FIGURA 6.11 - Variação da tensão de pré-adensamento e da tensão de ruptura com a sucção.

FIGURA 6.12 - Variação da tensão de pré-adensamento e da tensão de ruptura com a sucção. 
FIGURA 6.13 - Variação da tensão de pré-adensamento e da tensão de ruptura com a sucção.

FIGURA 6.14 - Variação da tensão de pré-adensamento e da tensão de ruptura com a sucção.

FIGURA 6.15 - Comparação entre os valores da umidade volumétrica obtidos com a curva característica de sucção do solo para a profundidade de $2,0 \mathrm{~m}$.

FIGURA 6.16 - Comparação entre os valores da umidade volumétrica obtidos com a curva característica de sucção do solo para a profundidade de $5,0 \mathrm{~m}$.

FIGURA 6.17 - Comparação entre os valores da umidade volumétrica obtidos com a curva característica de sucção do solo para a profundidade de $7,0 \mathrm{~m}$. 


\section{LISTA DE TABELAS}

TABELA 3.1 - Frações granulométricas constituintes dos solos.

TABELA 3.2 - Valores de peso específico seco e teor de umidade obtidos ao longo do perfil de coleta de blocos indeformados (MACHADO, 1998)

TABELA 3.3 - Resultados dos ensaios de caracterização e compactação (MACHADO, 1998)

TABELA 4.1 - Características das provas de carga.

TABELA 5.1 - Valores de sucção matricial obtidos nas provas de carga.

TABELA 5.2 - Valores do teor de umidade obtidos nas provas de carga.

TABELA 6.1 - Características das provas de carga realizadas por COSTA (1999).

TABELA 6.2 - Redução da tensão de ruptura para recalque de $25 \mathrm{~mm}$ em relação à tensão de colapso para as profundidades de $1,5,4,0$ e $6,0 \mathrm{~m}$.

TABELA 6.3 - Redução da tensão de ruptura de Pacheco Silva (1970) em relação à tensão de colapso para as profundidades de 1,5, 4,0 e 6,0 m. 


\section{LISTA DE FOTOS}

FOTO 01 - Placa utilizada para profundidades maiores que $2 \mathrm{~m}$.

FOTO 02 - Detalhe do indicador de deformações.

FOTO 03 - Detalhe da torre de transferência de carga utilizada para a profundidade de $1,5 \mathrm{~m}$.

FOTO 04 - Detalhe da torre de transferência de carga utilizada para as profundidades de 4,0, 6,0 e 8,0 m.

FOTO 05 - Detalhe das hastes para medidas de recalque.

FOTO 06 - Detalhe da bomba elétrica, macaco hidráulico, célula de carga e rótula.

FOTO 07 - Detalhe do pórtico utilizado para serviços diversos. 


\title{
LISTA DE ABREVIATURAS E SIGLAS
}

\author{
ABNT - Associação Brasileira de Normas Técnicas \\ CPT - Cone Penetration Test (Ensaio de penetração do cone) \\ EESC - Escola de Engenharia de São Carlos \\ IPT - Instituto de Pesquisas Tecnológicas \\ MML - Mixed Mantained Load Test (Ensaio Misto) \\ N.A. - Posição do lençol freático \\ NBR - Norma Brasileira Registrada \\ QML - Quick Mantained Load Test (Ensaio Rápido) \\ SML - Slow Mantained Load Test (Ensaio Lento) \\ SPT - Standard Penetration Test \\ USP - Universidade de São Paulo
}




\section{LISTA DE SÍMBOLOS}

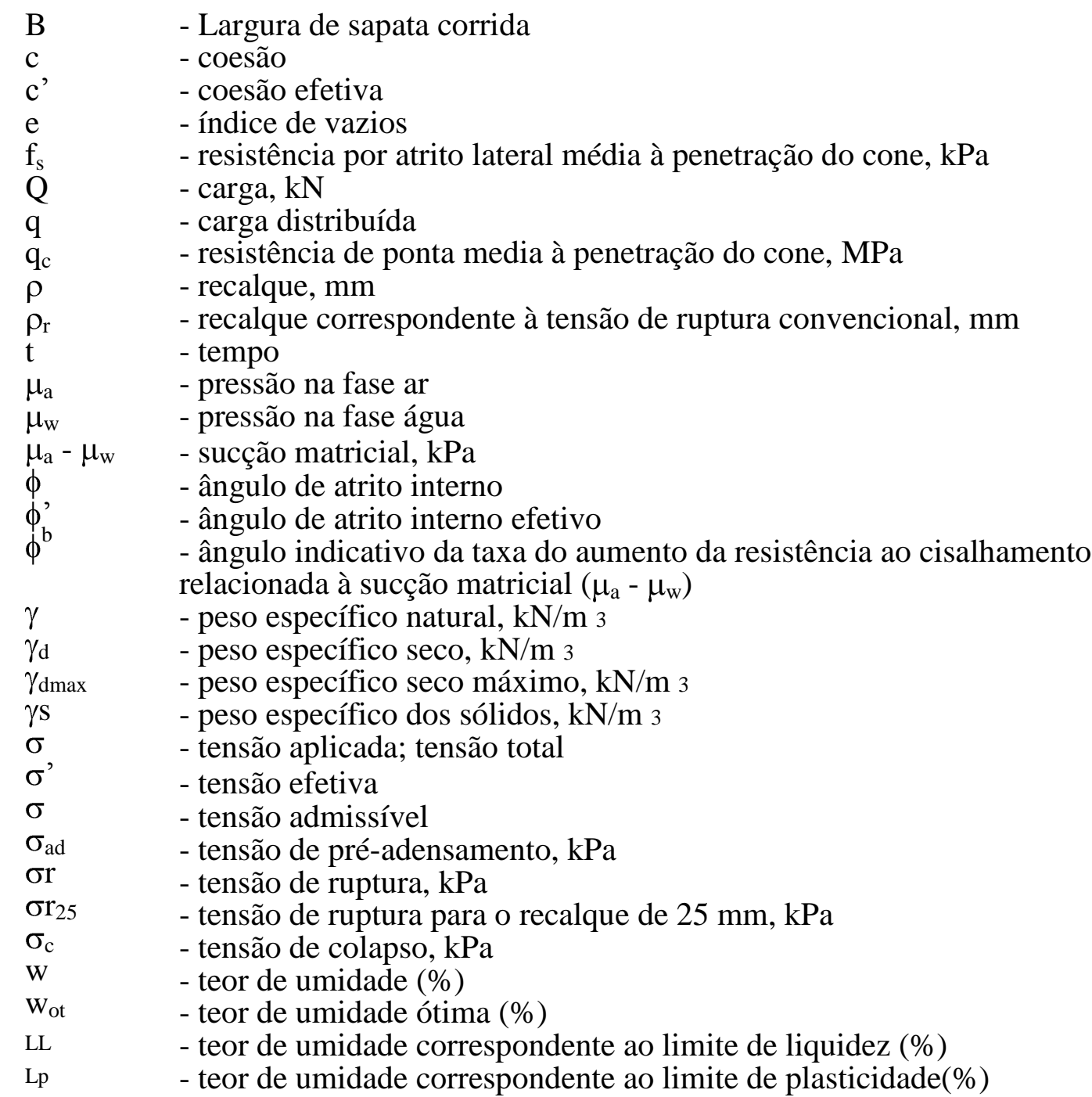




\section{RESUMO}

MACACARI, M.F. (2001). Variação da capacidade de carga com a sucção e profundidade em ensaios de placa em solo colapsível. São Carlos, 2001. 96p. Dissertação (Mestrado) - Escola de Engenharia de São Carlos, Universidade de São Paulo.

Este trabalho apresenta os resultados de provas de carga em placa com monitoramento da sucção matricial e do teor de umidade, realizadas nas profundidades de 1,5 , 4,0 , 6,0 e 8,0 m no Campo Experimental de Fundações da Escola de Engenharia de São Carlos, cujo perfil geotécnico é representativo da região centro-oeste do Estado de São Paulo. Para cada profundidade também se realizou ensaios com pré-inundação do terreno, representando a condição de sucção matricial nula. Constatou-se que a profundidade e a sucção matricial média no solo sob a placa influem significativamente na capacidade de carga do sistema solo-placa. As curvas tensão x recalque obtidas não caracterizam ruptura nítida nem indicam o modelo de ruptura física, exigindo assim a adoção de critérios de ruptura convencional. Devido à semelhança dessas curvas com as curvas e x $\log \sigma$ de ensaios de adensamento e, por isso, utilizou-se o método de PACHECO SILVA (1970) como um critério ruptura convencional, comparando-se com valores da tensão de pré-adensamento obtidos em laboratório. Também se utilizou o recalque de $25 \mathrm{~mm}$ para obter a correspondente ruptura convencional.

Palavras-chave: capacidade de carga; prova de carga em placa; solos não saturados; solos colapsíveis. 


\begin{abstract}
MACACARI, M.F. (2001) - Variation of the bearing capacity with suction and depth in plate load tests in collapsible soil. São Carlos, 2001. 96p. Dissertação (Mestrado) - Escola de Engenharia de São Carlos, Universidade de São Paulo.
\end{abstract}

This work presents the results of plate load tests with measurements of soil matric suction and moisture content, carried out in the depths of 1,5, 4,0, 6,0 and 8,0 $\mathrm{m}$ at the Experimental Field of Foundations of School of Engineering of São Carlos, whose soil profile is representative of the middle-west region of the State of São Paulo. For each depth tests with previous flooding of the land, representing the condition of null matric suction. Were also carried out It was verified that the depth and the average matric suction in the soil under the plate influence significantly in the load capacity of the soil-plate system. The stress settlement curve obtained does not characterize clear rupture nor indicate the model of physical rupture, demanding the adoption of approaches of conventional rupture. Due to the similarity of those curves with the e $\mathrm{x} \log \sigma$ curves from consolidation tests and, to put that, PACHECO SILVA (1970) method was used as an approach to conventional rupture, being compared with values of the preconsolidation stress obtained in laboratory. It was also used settlement of $25 \mathrm{~mm}$ to obtain the corresponding conventional rupture.

soils

Key-words: load capacity; plate load test; unsatured soils; collapsible 


\section{1 - INTRODUÇÃO}

As provas de carga em placa têm sido utilizadas para caracterizar solos colapsíveis superficiais. Porém a grande maioria das pesquisas em que se realizaram provas de carga em placa tinha como objetivo apenas quantificar a redução da capacidade de carga devido à colapsibilidade. Em estudo pioneiro no mundo todo, COSTA (1999) demonstrou a influência da sucção matricial na capacidade de carga através de ensaios de placa a 1,5m de profundidade.

Em continuidade ao trabalho de COSTA (1999), e com o objetivo de verificar o efeito da profundidade nos resultados das provas de carga, foram realizadas 11 provas de carga em placa circular com 0,80 m de diâmetro, no Campo Experimental de Fundações do Departamento de Geotecnia USP/São Carlos, a 1,5 , 4,0 , 6,0 e 8,0 $\mathrm{m}$ de profundidade, sendo que 4 ensaios foram realizados com préinundação do terreno, por um período mínimo de 48 horas.

Nos demais 7 ensaios, realizados sem inundação do terreno, obteve-se a sucção média sob a placa através de tensiômetros instalados no fundo da cava e procedeu-se a determinação do teor de umidade do solo em amostras deformadas, coletadas por tradagem.

As provas de carga foram executadas em quatro cavas com diâmetro aproximado de 1,0m, escavadas manualmente até atingir a profundidade desejada para a realização do ensaio. Terminado o ensaio, retirava-se a placa e escavava-se até atingir a próxima cota desejada, assim sucessivamente até atingir a cota de $-8,0 \mathrm{~m}$. A partir daí iniciava-se uma nova sequência em outra cava. 
O mecanismo de transferência de carga (do esquema de reação até a placa) era composto por torre metálica, que para as profundidades de 4,0,6,0 e 8,0m era subdividida em módulos de 2,0 m de comprimento, interligados por parafusos.

Nas curvas tensão x recalque obtidas nas provas de carga, verificou-se a existência de um trecho final praticamente linear não caracterizando uma ruptura nítida do sistema, nem possibilitando aplicar o modelo de ruptura física. Por isso, foram adotados dois critérios de ruptura convencional. Como primeiro critério de ruptura convencional adotou-se o valor da tensão de ruptura que corresponde ao recalque de $25 \mathrm{~mm}$. Outro critério de ruptura convencional foi considerado devido à semelhança da forma da curva tensão x recalque obtida nas provas de carga com a da curva e $\mathrm{x} \log \sigma$ de um ensaio de adensamento. Por isso aplicou-se o método PACHECO SILVA (1970) em todas as provas de carga, para determinar uma espécie de tensão de pré-adensamento.

Nas análises realizadas verificou-se a influência da sucção matricial e da profundidade na tensão de ruptura convencional, para ambos critérios de ruptura adotados. Também é realizada a comparação entre os resultados obtidos nas provas de carga e os resultados de ensaios edométricos, realizados por MACHADO (1998), com respeito à tensão de pré-adensamento e à tensão de ruptura.

Comparando os resultados das provas de carga inundadas com as não inundadas, é possível estimar a redução da tensão de ruptura convencional, para ambos critérios de ruptura adotados, devido à colapsibilidade do solo.

Por fim, faz-se uma comparação entre os valores do teor de umidade volumétrica e de sucção matricial obtidos durante as provas de carga, com a curva característica de sucção do solo obtida por MACHADO (1998). 


\section{2 - REVISÃO BIBLIOGRAFICA}

\section{1 - Solos colapsíveis}

Alguns solos não saturados apresentam um comportamento tensão x deformação peculiar. Se for aumentado seu teor de umidade, mantido um certo estado de tensões, esses solos sofrem uma brusca e acentuada redução de volume devido ao colapso de sua estrutura (figura 2.1). Por esse motivo usa-se a denominação solo colapsível.

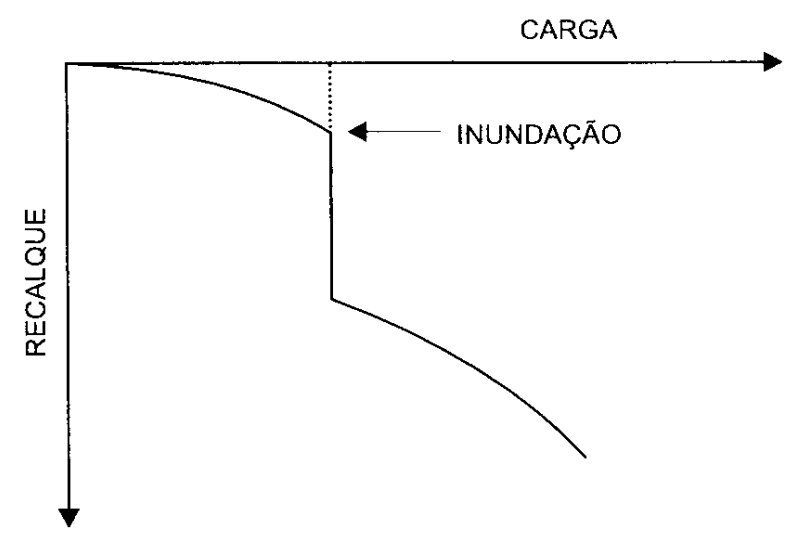

FIGURA 2.1: Ocorrência de colapso em prova de carga realizada com inundação do solo durante o ensaio (CINTRA, 1998).

Este fenômeno explica os problemas que ocorrem em fundações rasas implantadas neste tipo de solo, que durante algum tempo apresentaram bom 
comportamento, porém com o surgimento de uma fonte de água apresentaram problemas decorrentes de recalques diferenciais significativos. A fonte de água pode ocorrer devido ao rompimento de tubulações de água ou esgoto (figura 2.2), infiltração de águas pluviais, trincas em reservatórios subterrâneos, ascensão do lençol freático, etc.
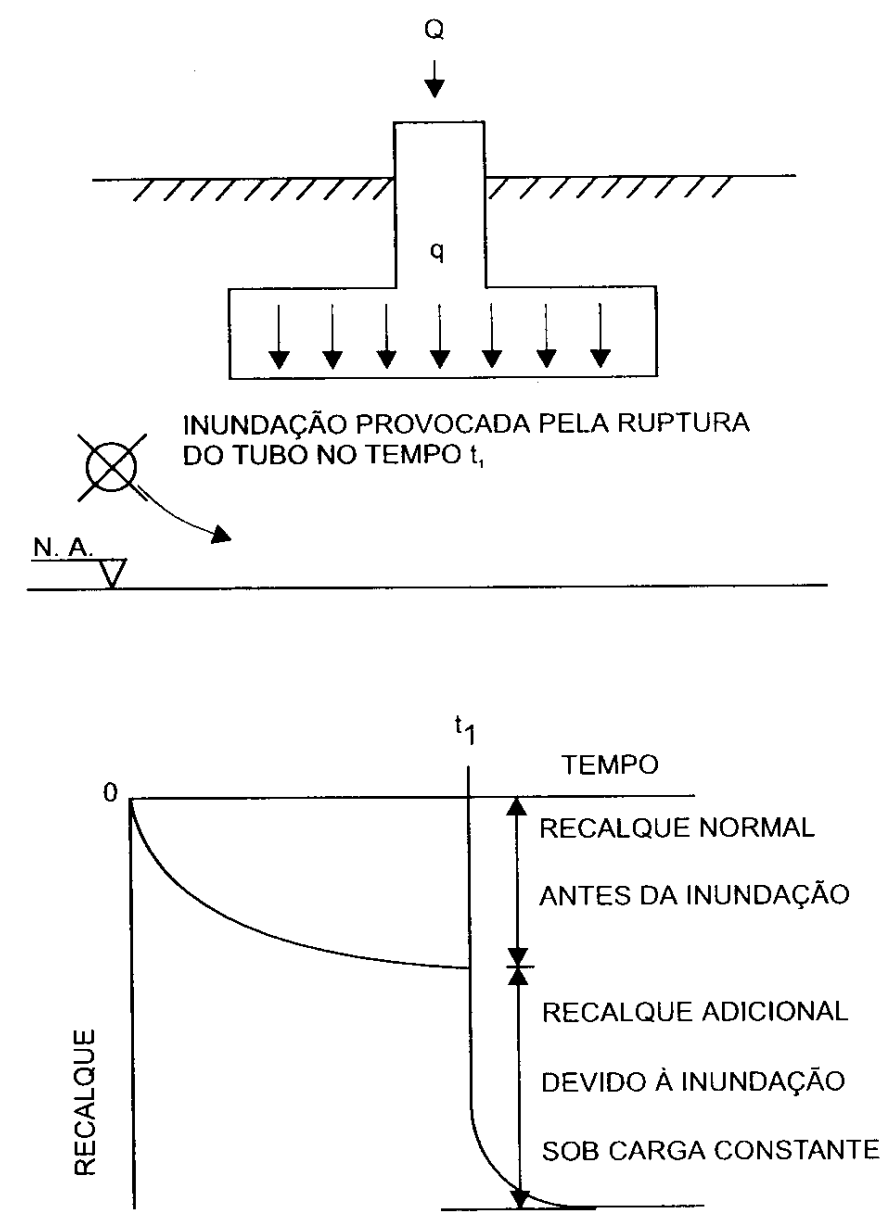

FIGURA 2.2: Conceito básico de recalque adicional devido ao colapso da estrutura do solo (JENNINGS \& KNIGHT (1975) apud CINTRA, 1998).

Em provas de carga com inundação prévia ao início do carregamento, o colapso não fica caracterizado por recalque abrupto (figura 2.1), mas pelo aumento 
da deformabilidade e conseqüente redução da capacidade de carga, como pode ser observado na figura 2.3 .

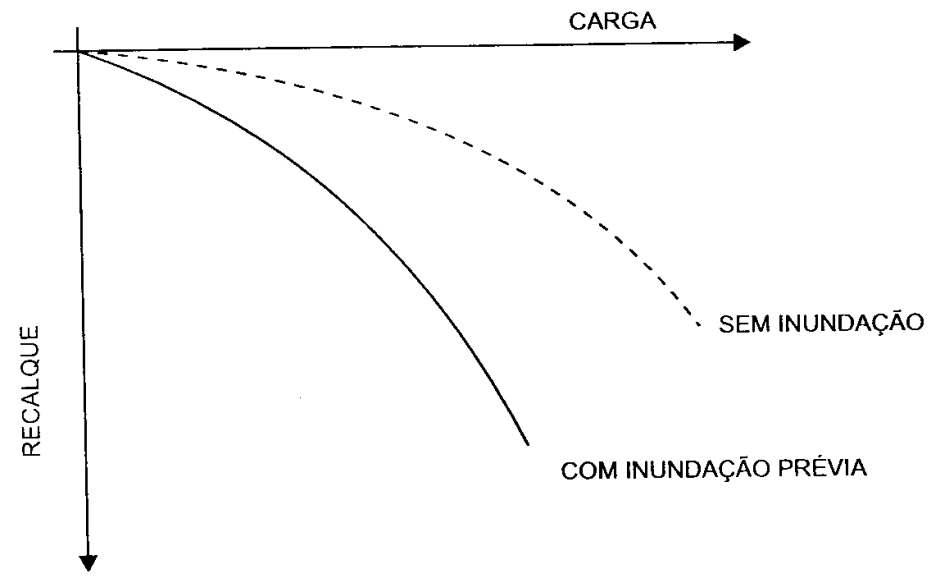

FIGURA 2.3: Prova de carga em solo colapsível previamente inundado (CINTRA, 1998).

Os solos colapsíveis geralmente apresentam: estrutura porosa, caracterizada por um alto índice de vazios, e condição não saturada, representada por um baixo teor de umidade. A presença de um agente cimentante, aliado a um determinado valor de sucção, garante a estabilidade do solo na condição parcialmente saturada, conferindo-lhe uma resistência "aparente".

Porém, essa resistência "aparente" é instável diante do aumento do teor de umidade, o qual ao atingir um limite crítico provocará o colapso, desde que a carga atuante esteja acima de um certo limite.

\subsection{1 - Ocorrência de solos colapsíveis}

A grande ocorrência desse tipo de solo no Brasil pode ser explicada por se tratar de um país de clima tropical. Segundo VILAR et al. (1981) "as regiões tropicais apresentam condições flagrantes para o desenvolvimento de solos 
colapsíveis, quer pela lixiviação de finos dos horizontes superficiais nas regiões onde se alternam estações de relativa seca e de precipitações intensas, quer pelos solos com deficiência de umidade que se desenvolvem em regiões áridas e semiáridas." Esses autores também fazem menção à ocorrência de solos colapsíveis em regiões com outros tipos de clima.

No Brasil, os solos colapsíveis ocorrem em diversas regiões e geralmente estão associados a depósitos recentes, sejam eles de origem coluvionar, aluvionar e residual que passaram por uma intensa lixiviação. A figura 2.4 exibe alguns locais de ocorrência de solos colapsíveis no Brasil, catalogados em 1989.

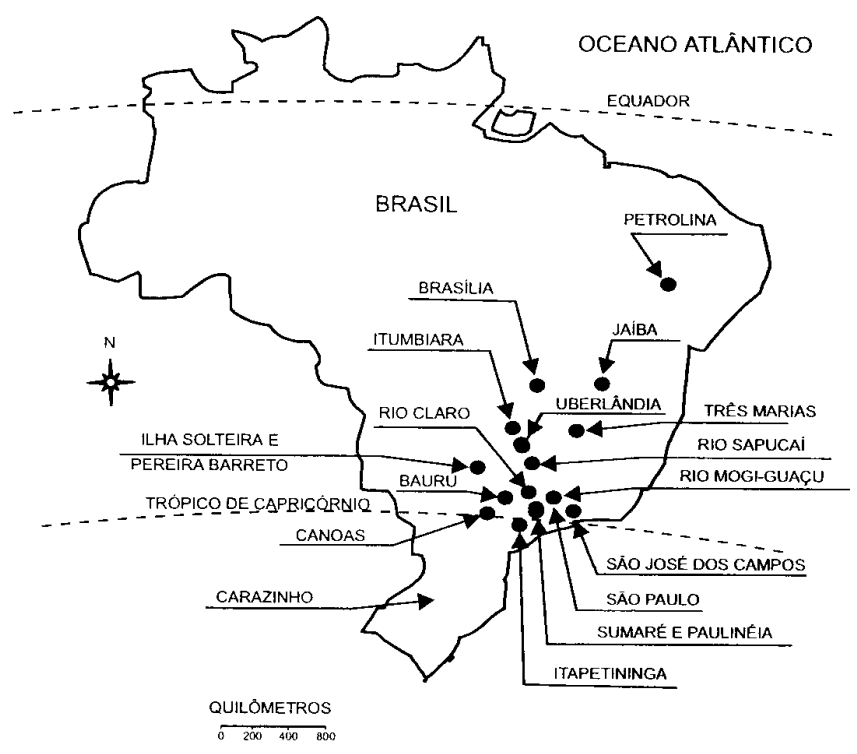

FIGURA 2.4: Solos colapsíveis estudados no Brasil (FERREIRA et al.,1989 apud CINTRA, 1998).

No Estado de São Paulo, pode-se citar como exemplos de solos colapsíveis a argila porosa vermelha (do terciário) da Cidade de São Paulo, que é extremamente porosa e compressível, e o sedimento cenozóico que cobre grande parte do interior do estado, como pode ser observado na figura 2.5. 


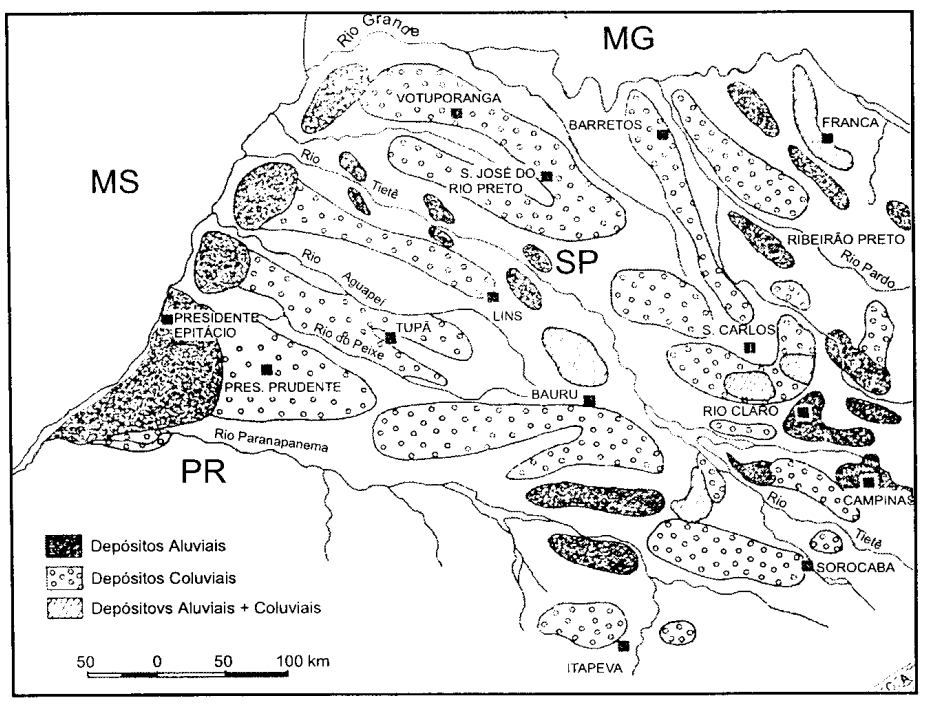

FIGURA 2.5: Distribuição dos depósitos de cobertura cenozóica no interior do Estado de São Paulo (FULFARO \& BJORNBERG (1993) apud CINTRA, 1998).

\section{2 - Prova de carga em placa}

A prova de carga em placa é um ensaio de campo, realizado na superfície ou em profundidade, cuja finalidade reside na verificação do comportamento de um elemento de fundação sujeito a um determinado carregamento de compressão e na estimativa de parâmetros indicativos de resistência e de deformabilidade do solo suporte da futura construção (COSTA, 1999).

É o mais antigo ensaio "in situ” de compressão, sendo que no Brasil um dos trabalhos pioneiros é de autoria de CUNHA (1920) que realizou vários experimentos em terrenos para o estudo de fundações (apud BARATA, 1984).

Outros trabalhos também podem ser citados como pioneiros em provas de carga em placa, como por exemplo o de NAPOLES NETO (1954) que realizou estudos de recalques em um solo residual de gnaisse, o de SOUTO SILVEIRA \& SILVEIRA (1958) que realizaram uma prova de carga na cidade de São Carlos com o objetivo de obter correlações com ensaios de laboratório, assim 
como o estudo realizado pelo IPT (1954) na cidade de São Carlos para as instalações da Escola de Engenharia de São Carlos, cujos resultados de três provas de carga em placa realizadas podem ser observados nas figuras 2.6 a 2.8 .

Tensão ( kPa )

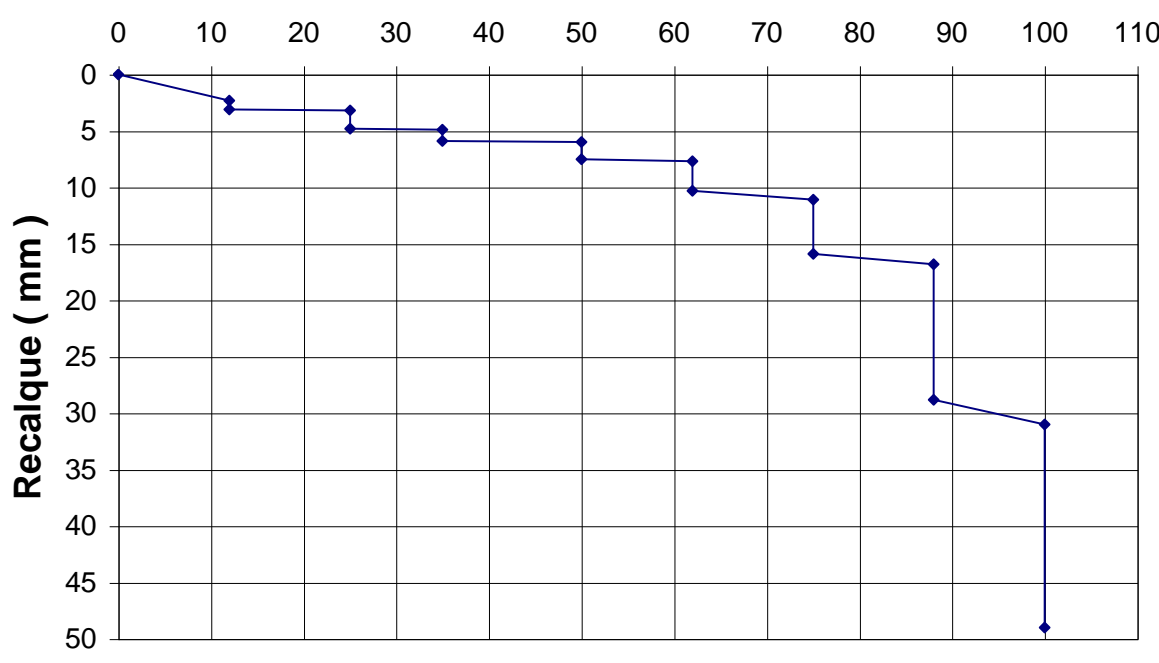

FIGURA 2.6: Curva tensão x recalque para a profundidade de $1,0 \mathrm{~m}$.

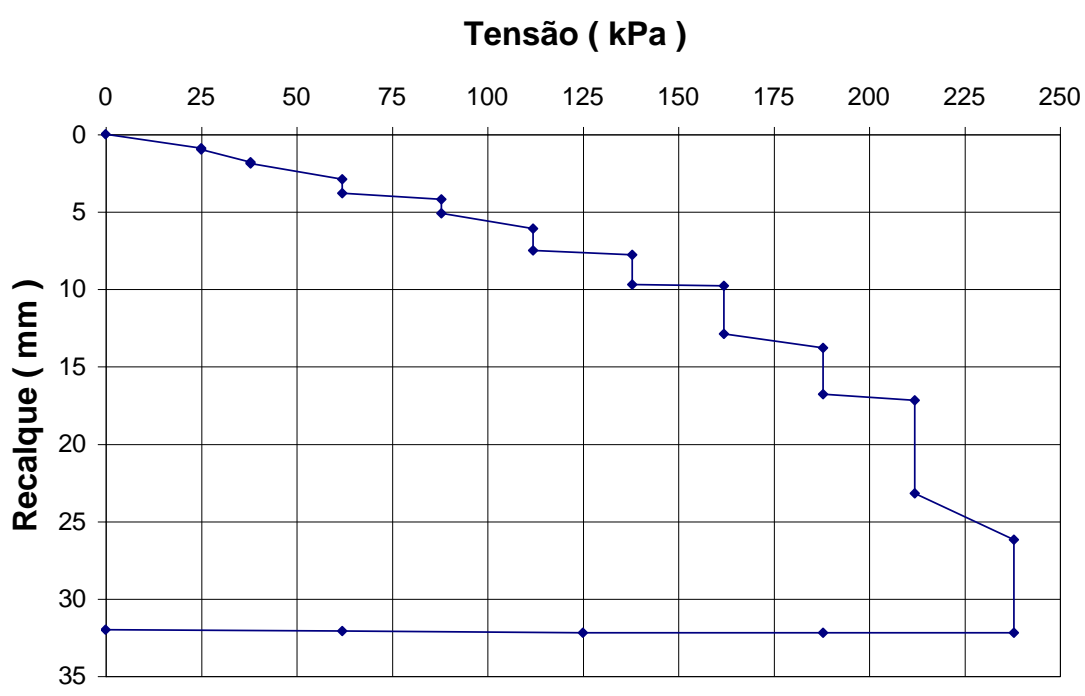

FIGURA 2.7: Curva tensão x recalque para a profundidade de $5,0 \mathrm{~m}$. 


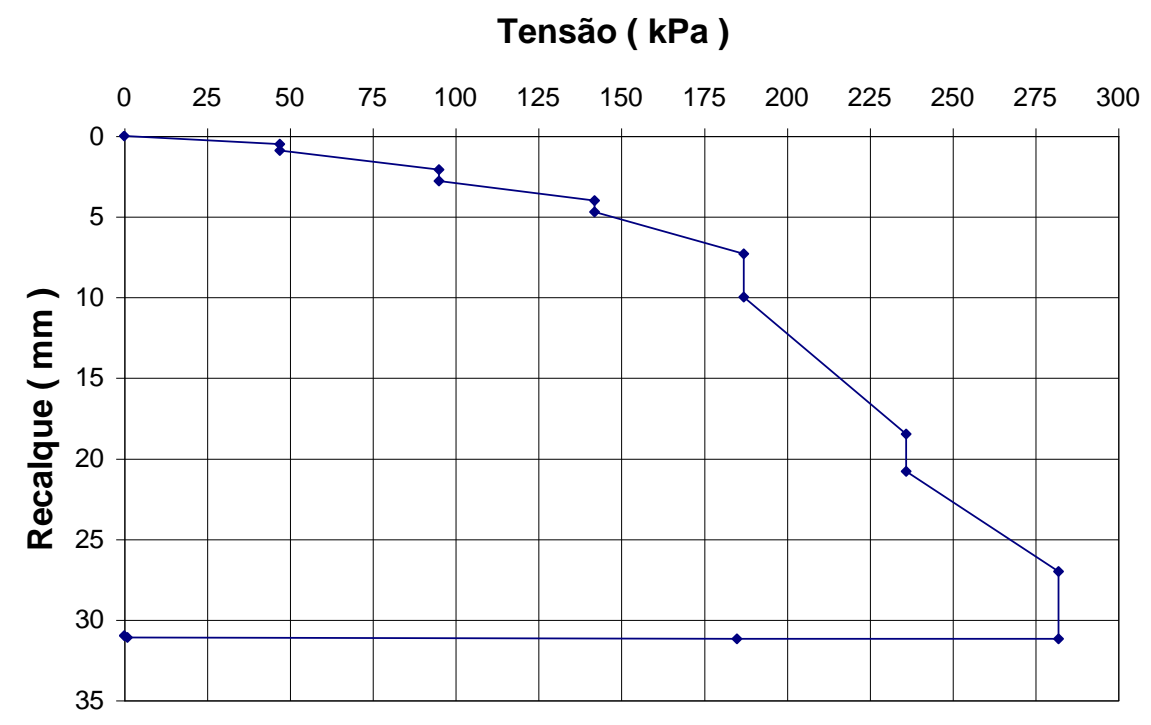

FIGURA 2.8: Curva tensão $\mathrm{x}$ recalque para a profundidade de $7,0 \mathrm{~m}$.

AGNELLI \& ALBIERO (1994) analisaram provas de carga realizadas por AGNELLI (1992), na cidade de Bauru/SP, nas profundidades de 1 e $2 \mathrm{~m}$, e concluíram que o solo estudado apresenta baixa capacidade de carga e possuí caráter colapsível, não recomendando o emprego de fundações rasas em terreno com as mesmas características geotécnicas. Os resultados dessas provas de carga podem ser vistos nas figuras 2.9 e 2.10
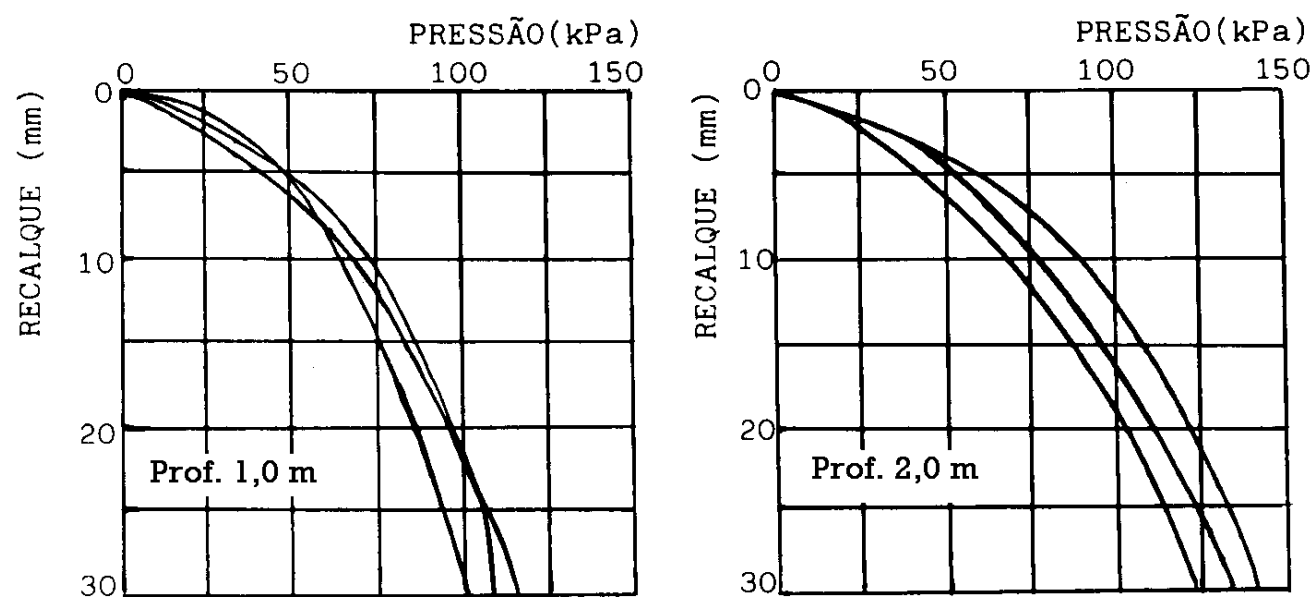

FIGURA 2.9: Curva pressão x recalque para a profundidade de 1,0 e $2,0 \mathrm{~m}$ (não inundado). 

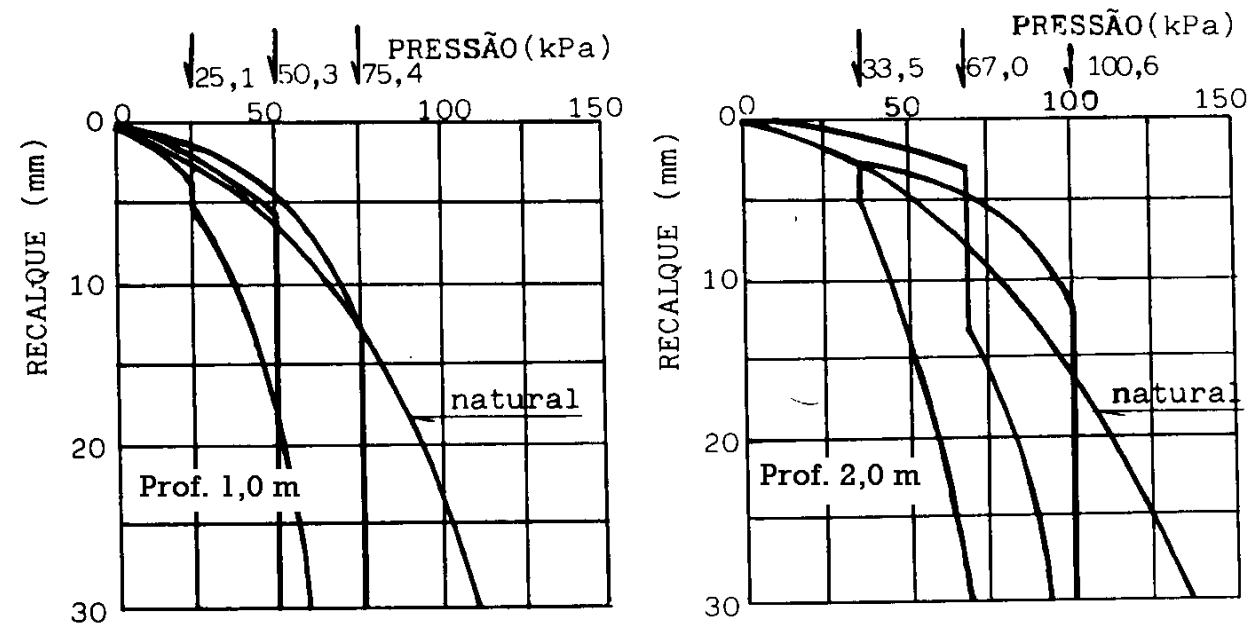

FIGURA 2.10: Curva pressão x recalque para a profundidade de 1,0 e $2,0 \mathrm{~m}$ (inundado), comparada a de um ensaio não inundado.

\section{3 - Tipos de ensaio}

\subsection{1 - Ensaio rápido (Quick maintained load test - QML)}

No Brasil, não há uma norma específica para a realização do ensaio rápido e, por isso, costuma-se adotar as prescrições da MB - 3472/91 - "Estacas Prova de Carga Estática”.

As especificações da MB - 3472/91 dizem que a tensão aplicada em cada estágio não deve ser superior a $10 \%$ da tensão admissível prevista e permanecerá por cinco minutos, fazendo-se leitura de deslocamentos pelo menos no início e no término de cada estágio de carga. Caso não ocorra ruptura ou deslocamento excessivo do solo, o ensaio deve ser conduzido até o dobro da tensão admissível prevista. O descarregamento deve ser feito em quatro estágios, com 
leituras dos respectivos deslocamentos. A leitura final deve ser realizada dez minutos após o descarregamento total.

Segundo FELLENIUS (1975), cada estágio de carga deve ser mantido por quinze minutos com leituras de deslocamentos a cada 3 minutos.

\subsection{2 - Ensaio lento (Slow mantained load test - SML)}

Este tipo de ensaio é prescrito pela NBR 6489/84 da ABNT - "Provas de carga direta sobre terreno de fundação". Suas especificações dizem que a tensão aplicada em cada estágio não deve ser superior a $20 \%$ da tensão admissível provável do solo, sendo que a mudança de estágio deve ocorrer:

"Quando a diferença entre duas leituras de recalques realizadas nos tempos $\mathrm{t}$ e $\mathrm{t} / 2$ não ultrapassarem $5 \%$ do deslocamento total ocorrido no correspondente estágio de carregamento".

A NBR 6489/84 especifica ainda que o ensaio deve atingir no mínimo o recalque de $25 \mathrm{~mm}$ ou o dobro da tensão admissível provável do solo, sendo que a tensão máxima deve ser mantida pelo menos por 12 horas, caso a ruptura não ocorra. As leituras de recalques em cada estágio devem ser realizadas imediatamente após a aplicação de carga e a seguir em intervalos dobrados de tempo $(1,2,4,8,15,30, \ldots)$.

O descarregamento deve ser realizado em quatro estágios, lendo-se os correspondentes recalques. Os estágios de descarregamento devem ser mantidos até a estabilização.

\subsection{3 - Ensaio misto (Mixed mantained load test - MML)}

De MELLO (1975) sugeriu que tal modalidade de ensaio fosse incluída na norma brasileira de prova de carga vigente naquela época. Mais 
recentemente, esta discussão foi reavivada por ALONSO (1997), com referência a provas de carga mistas em estacas.

Este tipo de ensaio é realizado em duas fases: lenta (SML) e rápida (QML). COSTA (1999) realizou três provas de carga mistas inundadas em placa a 1,5 m de profundidade no Campo Experimental de Fundações da USP/São Carlos, cujos resultados podem ser observados na figura 2.11 .

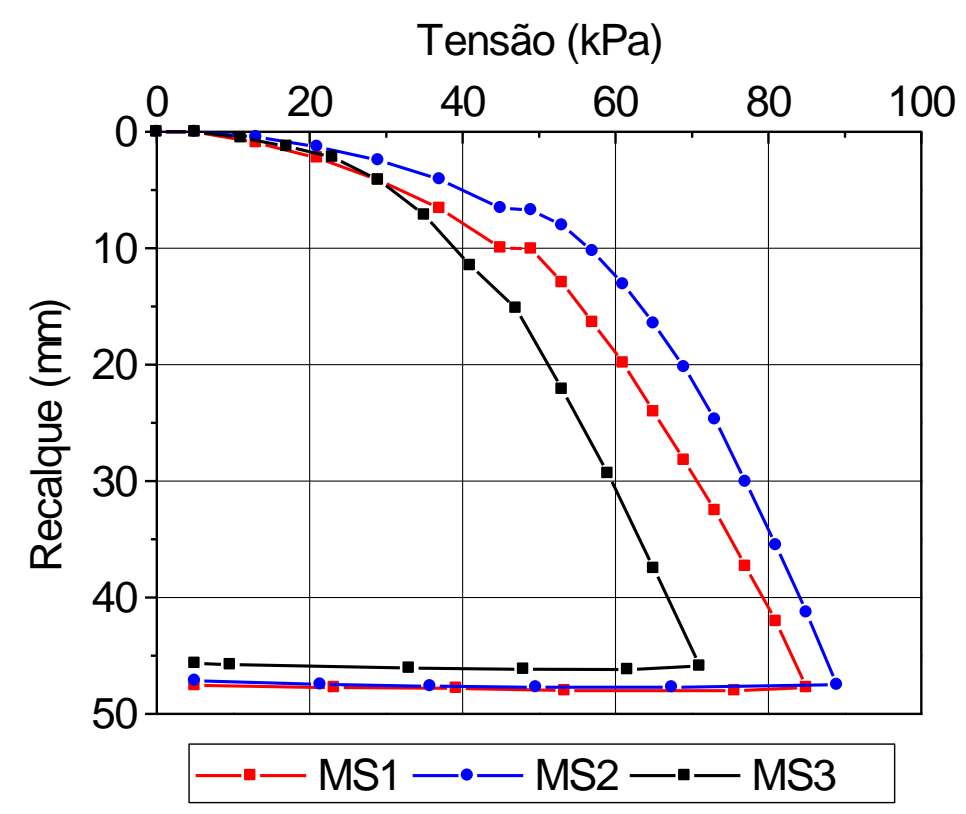

FIGURA 2.11: Curvas tensão x recalque dos ensaios MML inundados (COSTA, 1999)

Para a realização dessas provas de carga COSTA (1999) adotou como critério para mudança do tipo de ensaio, o valor da tensão admissível provável, desde que os deslocamentos tivessem atingido $10 \mathrm{~mm}$. $\mathrm{O}$ incremento de carga aplicado na fase rápida foi adotado como sendo igual à metade do incremento utilizado nos estágios da fase lenta. 
COSTA (1999) compara os ensaios rápidos, lentos e mistos em placa, realizados a 1,5 $\mathrm{m}$ de profundidade e observa que as curvas das provas de carga mista apresentam um comportamento semelhante ao das curvas dos outros dois tipos de ensaios (figura 2.12), concluindo ser viável sua aplicação ao solo estudado.

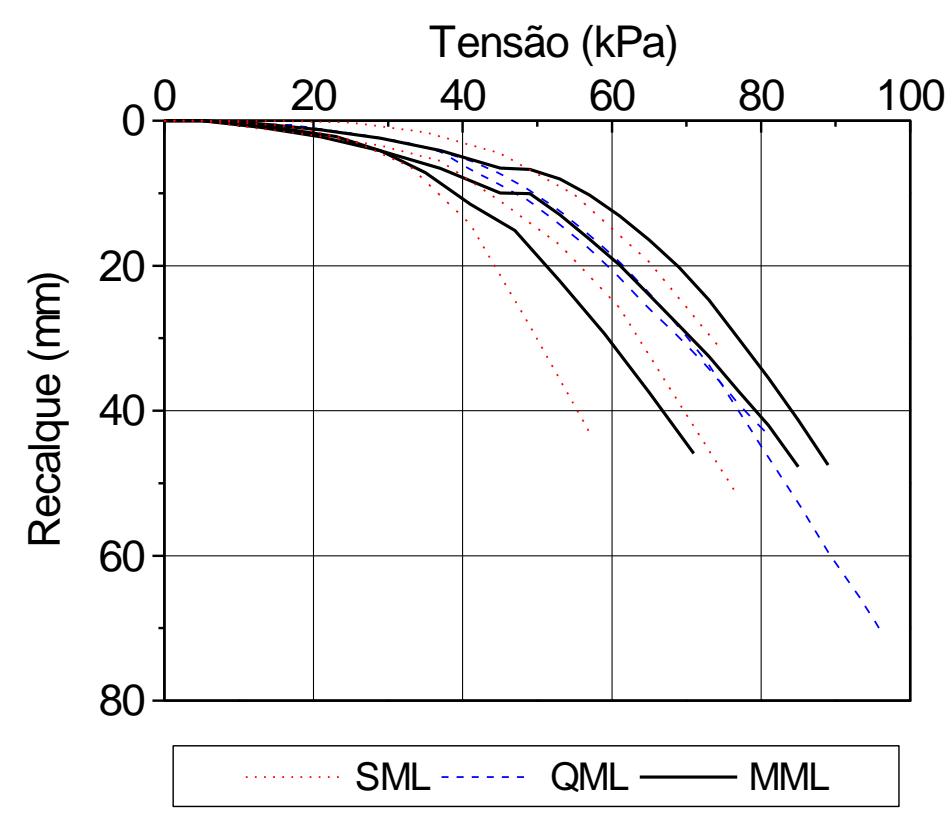

FIGURA 2.12: Comparação entre os ensaios SML, QML e MML (COSTA, 1999).

Analisando os resultados de provas de carga rápidas e lentas em placa realizadas por COSTA (1999) observou-se que as curvas tensão x recalque possuem forma semelhante para o solo estudado, porém um maior número de pares de ensaios rápidos e lentos com a mesma sucção é necessário para obter análises mais conclusivas. 


\section{4 - Influência da forma da placa na capacidade de}

\section{carga}

KÖEGLER \& FREIBERG (1931) apud MASSAD (1985) apresentam um estudo onde foram realizadas provas de carga com placas de área iguais, assentadas no mesmo tipo de solo, levadas até a ruptura, com diferentes formas da placa (círculo, quadrado, retângulo e triângulo).

Os autores concluem que a carga de ruptura cresce na seguinte sequiência de formato da placa: circular, quadrado, retangular curta, triangular e que quanto mais comprido o retângulo menor a capacidade de carga.

A figura 2.13 apresenta os resultados obtidos por FREIBERG, onde $\mathrm{F}$ é a área e U o perímetro da placa utilizada no ensaio.

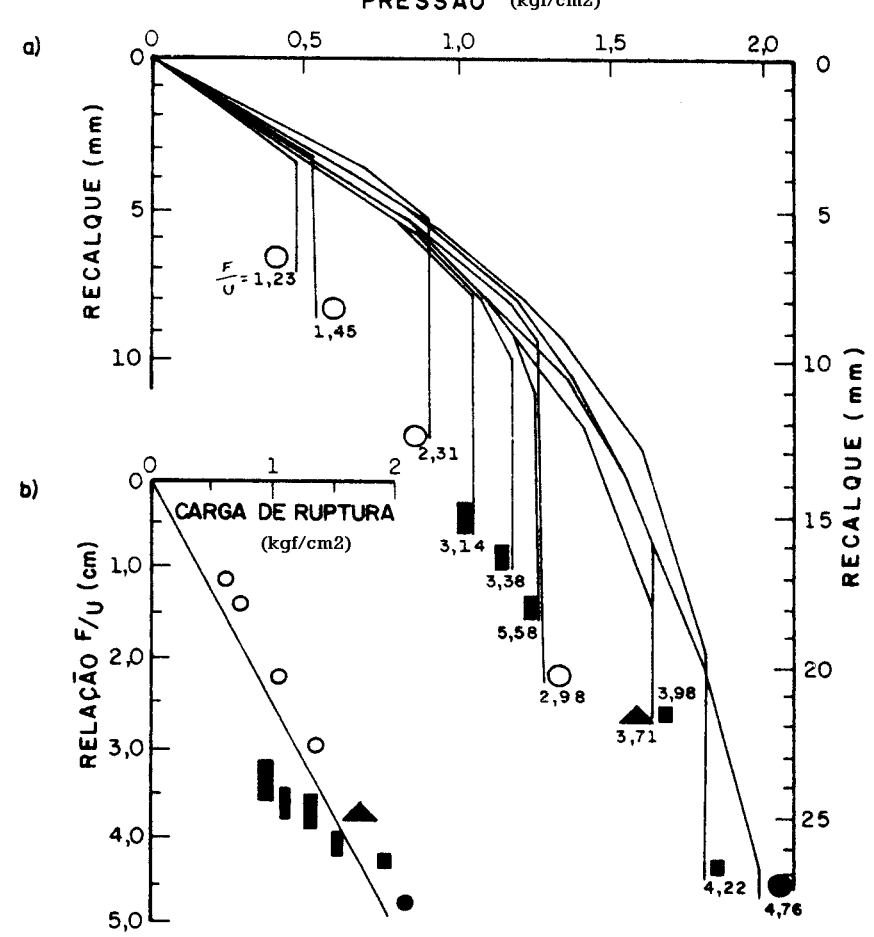

FIGURA 2.13: Influência da forma da placa na carga de ruptura (FREIBERG, 1931 apud MASSAD, 1985). 


\section{5 - Influência da dimensão da placa nos recalques}

\section{medidos}

Como na maioria dos casos, a placa utilizada em uma prova de carga possui dimensões menores às da fundação a serem realizadas, alguns pesquisadores estudaram o efeito escala sobre as dimensões da placa.

VARGAS (1978) apresenta um gráfico de recalques medidos em função do diâmetro das placas, este gráfico pode ser visualizado através da figura 2.14 .

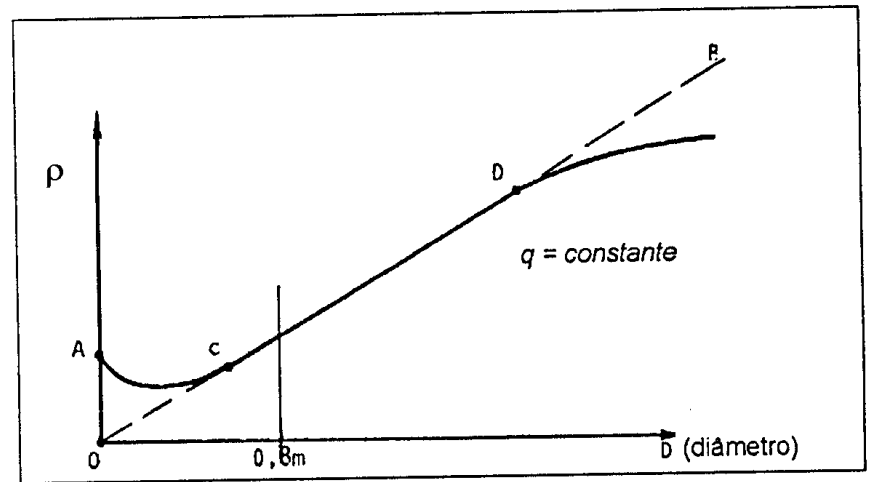

FIGURA 2.14: Relação entre recalque e o diâmetro da placa (Vargas, 1978 apud COSTA, 1999)

$\mathrm{Na}$ figura 2.14 observa-se a proporcionalidade entre o recalque e diâmetro apenas no trecho $\mathrm{CD}$. No trecho $\mathrm{AC}$ os recalques observados são maiores que os teóricos, devido ao puncionamento do terreno por placas de pequeno diâmetro. A partir do ponto D os recalques observados são menores que os teóricos, isto pelo fato do módulo de deformabilidade para alguns solos ser crescente com a profundidade, ou seja, se o diâmetro da placa é maior, o bulbo de pressão será maior, o que mobilizará um volume de solo maior abaixo da placa, assim os recalques serão menores. 
Observa-se que o diâmetro de 0,80 m que é adotado pela ABNT está dentro do trecho de proporcionalidade da figura 2.14.

DÉCOURT \& QUARESMA FILHO (1996) observaram que se os recalques forem adimensionalisados pelo lado ou diâmetro da placa e as tensões, pela tensão de ruptura convencional, o efeito escala não mais existirá e a extrapolação dos resultados de uma prova de carga em placa para uma fundação real não é mais necessário.

Conclusão semelhante foi obtida por CONSOLI et al. (1998) em ensaios em placas com diâmetros de 0,30,0,45,0,60 e em sapatas quadradas de $0,4,0,7$ e $1,0 \mathrm{~m}$.

\section{6 - Capacidade de carga}

A capacidade de carga de uma fundação é o valor da carga que leva o sistema (elemento estrutural e o maciço de solos que o envolve) à ruptura. Essa ruptura pode ser nítida, quando ocorre a penetração contínua do sistema sob ação de uma carga constante, convencional quando se define uma carga que corresponde a um recalque finito arbitrado, ou física quando caracteriza um valor assintótico para a tensão.

A capacidade de carga pode ser estimada por métodos teóricos, provas de carga sobre placa e métodos semi-empíricos e empíricos. Os inúmeros métodos disponíveis na literatura ainda não levam em consideração a influência da sucção no solo. Somente nos últimos anos, com o desenvolvimento da mecânica dos solos não saturados, passou-se a estudar a influência da sucção matricial na capacidade de carga.

Em âmbito teórico, a primeira tentativa de correlacionar a sucção com a capacidade de carga deve-se a FREDLUND \& RAHARDJO (1993) que utilizando a equação proposta por TERZAGHI (1943) para estimar a tensão de ruptura de um solo, demonstraram a influência da sucção matricial na capacidade de carga de um 
maciço de solo sob sapatas corridas de 0,5 e $1 \mathrm{~m}$ de largura a $0,5 \mathrm{~m}$ de profundidade. Esses resultados podem ser vistos na figura 2.15 .

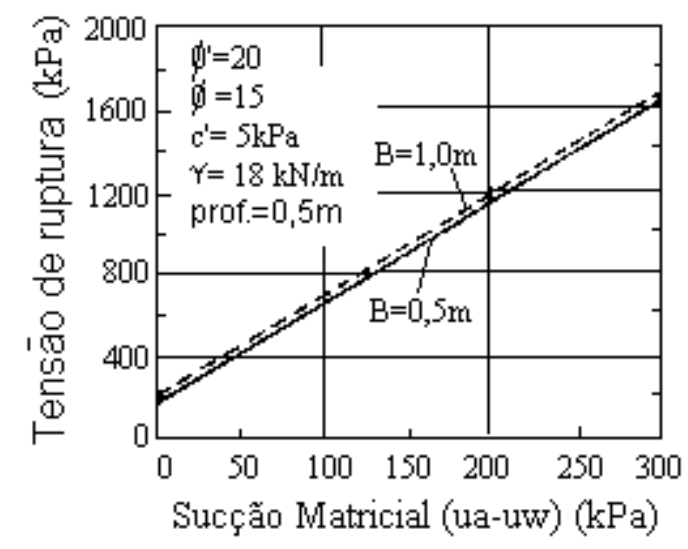

FIGURA 2.15: Variação da tensão de ruptura de sapatas corridas em função da sucção matricial (FREDLUND \& RAHARDJO, 1993)

Em termos experimentais a contribuição pioneira em termos mundiais deve-se a COSTA (1999), que realizou provas de carga em placa a 1,5 m de profundidade e concluiu que a sucção matricial possui grande influência na capacidade de carga do solo, pois um pequeno aumento na sucção causou um substancial crescimento da tensão de ruptura do solo, como pode ser observado nas figuras 2.16 e 2.17 . 


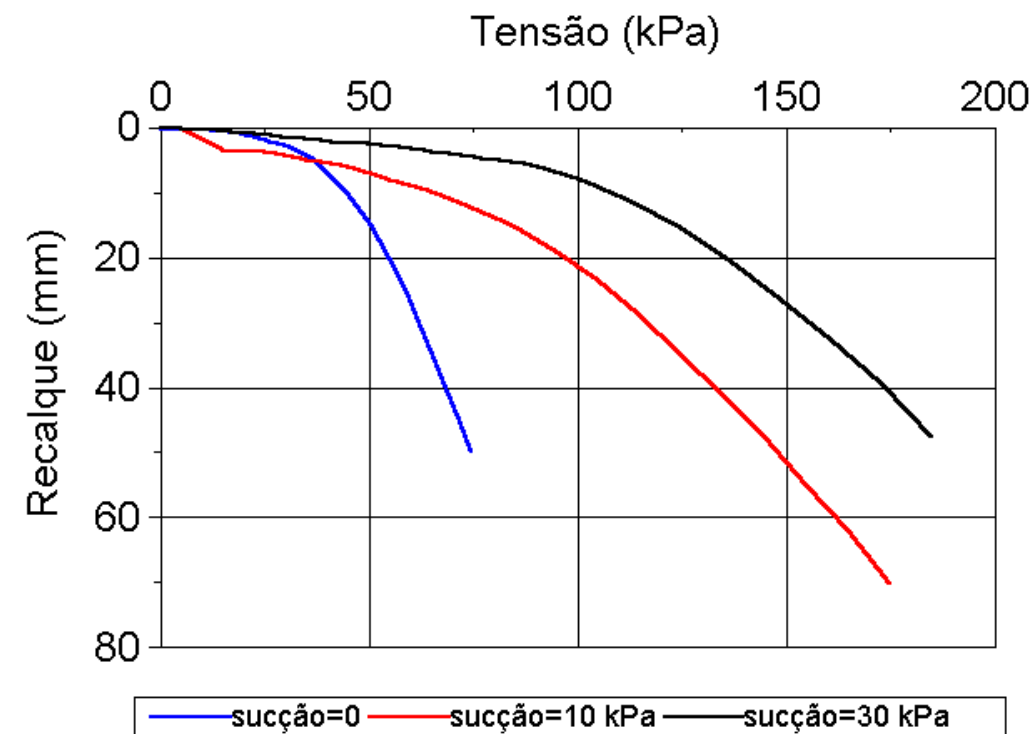

FIGURA 2.16: Curvas tensão x recalque dos ensaios SML (COSTA, 1999).

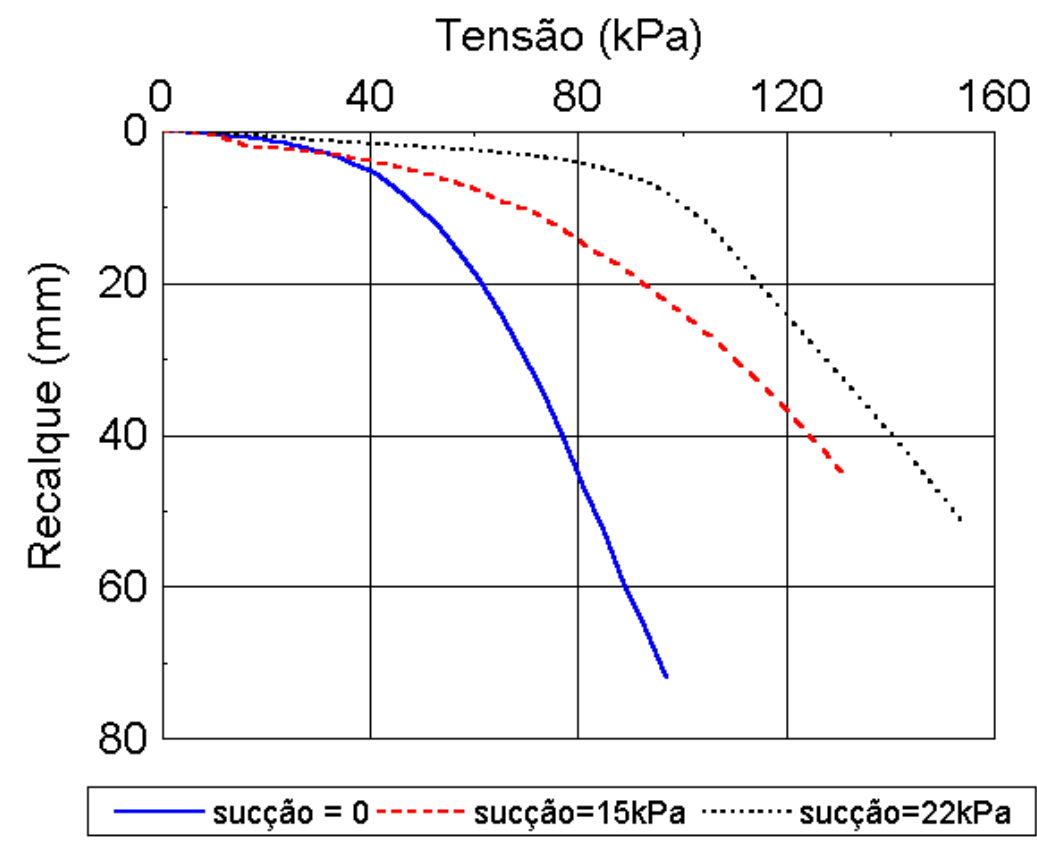

FIGURA 2.17: Curvas tensão x recalque dos ensaios QML (COSTA, 1999). 
Arbitrando como critério de ruptura o recalque de $25 \mathrm{~mm}$, COSTA (1999) ilustra o aumento da tensão de ruptura com o crescimento da sucção matricial, como pode ser observado na figura 2.18 .

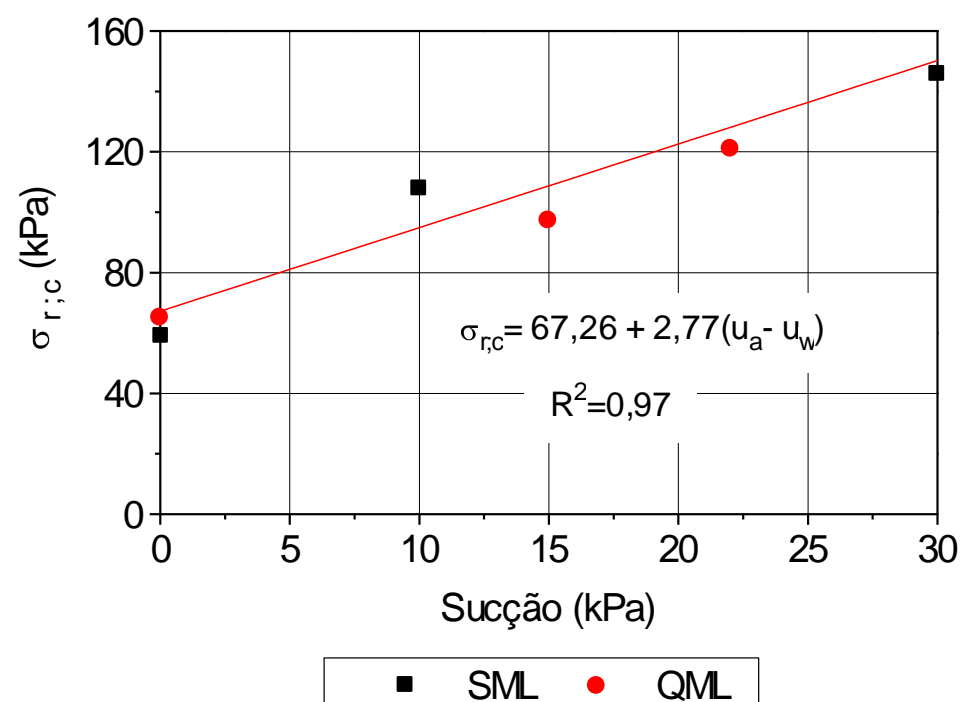

FIGURA 2.18: Variação da tensão de ruptura com a sucção matricial (COSTA, 1999) 


\section{3 - GEOLOGIA LOCAL}

A pesquisa desenvolveu-se no Campo Experimental de Fundações do Departamento de Geotecnia da Escola de Engenharia de São Carlos (EESC).

A cidade de São Carlos está localizada na região central do Estado de São Paulo e tem sua posição geográfica dada pelas coordenadas $22^{\circ} 01^{\prime} 22^{\prime \prime}$ de latitude sul e $47^{\circ} 53^{\prime} 38^{\prime}$ ' de latitude oeste. Seu relevo oscila na faixa de 750 a $950 \mathrm{~m}$.

A região de São Carlos está assentada sobre rochas do grupo São Bento, constituídas pelos arenitos da Formação Botucatu e Pirambóia, e pelos magmatitos básicos da Formação Serra Geral. Acima dessas formações rochosas ocorrem conglomerados e arenitos do Grupo Bauru e cobrindo toda a região, aparece uma camada de solo superficial, denominada de Sedimento Cenozóico, que é produto do retrabalhamento dos materiais do Grupo Bauru e das Formações Serra Geral e Botucatu, através de pequeno transporte em meio aquoso de "razoável competência"(BORTOLUCCI, 1983).

Trata-se de uma região tropical, com elevadas temperaturas e intensa precipitação pluviométrica, fato este que provocou na camada de solo superficial (Sedimento Cenozóico) características de material laterizado, baixo teor de umidade natural e de caráter colapsível.

No Campo Experimental de Fundações a espessura da camada de solo superficial de Sedimento Cenozóico é da ordem de $6 \mathrm{~m}$, sendo que o seu contato inferior é feito com solo residual do Grupo Bauru, não laterítico, descrito como areia argilosa vermelha, através de uma camada de aproximadamente $10 \mathrm{~cm}$ de seixos de quartzo e limonita (CINTRA et al., 1991). O nível d'água se encontra variando de $-8,0 \mathrm{a}-10,0 \mathrm{~m}$. 
A figura 3.1 mostra a seção esquemática da geologia da cidade de São Carlos.

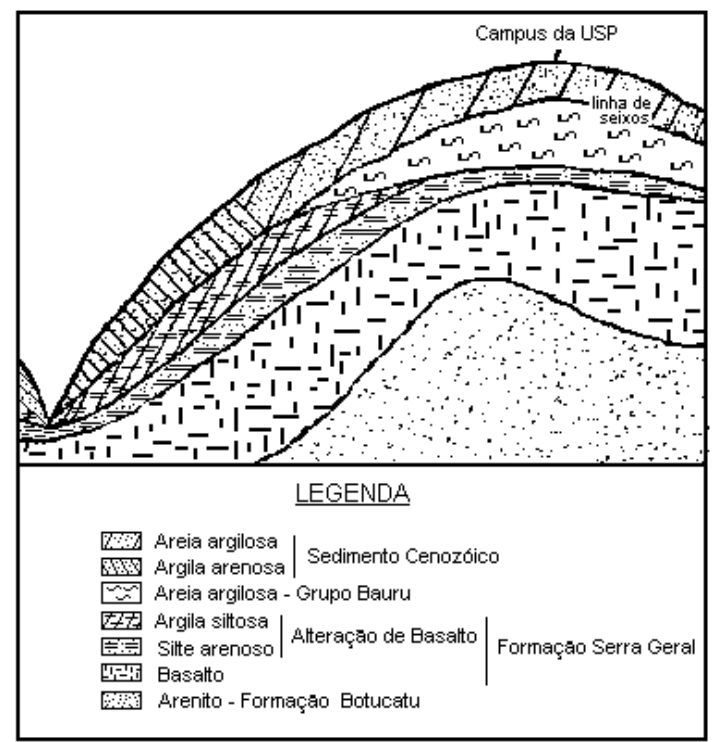

FIGURA 3.1: Seção esquemática da geologia de pequena profundidade em São Carlos (CINTRA et al.,1991)

\section{1) Caracterização geotécnica}

\subsection{1) Ensaios in situ}

Foram realizados 15 sondagens de simples reconhecimento (SPT) divididas em três campanhas de cinco furos, e oito ensaios de penetração estática (CPT) em duas campanhas: a primeira com cinco furos, utilizando cone mecânico e a segunda com três furos, utilizando cone elétrico. 
A figura 3.2 apresenta a estratificação do Campo Experimental de Fundações. Observa-se uma camada superficial de areia argilosa marrom escura (Sedimento Cenozóico) de cerca de 6,00 m de espessura. A partir dessa profundidade, separada por uma linha de seixos de aproximadamente $0,10 \mathrm{~m}$ de espessura, há uma camada formada por areia argilosa de cor variegada (Solo Residual do Grupo Bauru). O nível d'água se encontra variando de $-8,0 \mathrm{~m}$ a $-10,0$ $m$, em função da época de realização das sondagens.

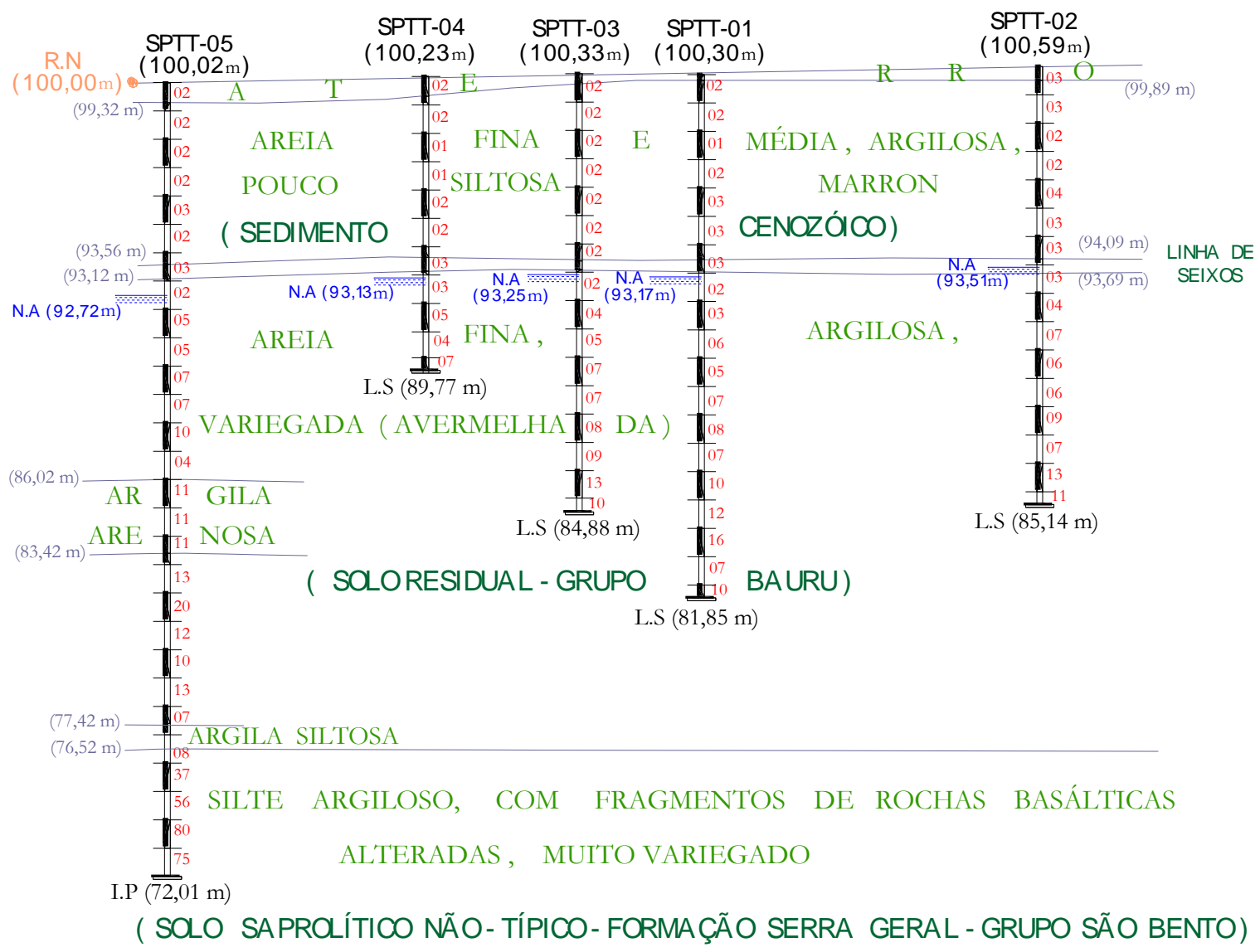

FIGURA 3.2: Perfil do terreno associado às sondagens à percussão ( SANTOS, 2001).

Santos (2001) também mostra a grande variabilidade das três campanhas de sondagem, através de um gráfico do número de golpes $\mathrm{N}_{\mathrm{SPT}}$ médio de cada campanha contra a profundidade (figura 3.3). Essa variabilidade é devido ao fato que as sondagens foram realizadas em diferentes épocas do ano (com períodos de seca e 
períodos de grandes precipitações intercalados) e, além disso, por empresas diferentes.

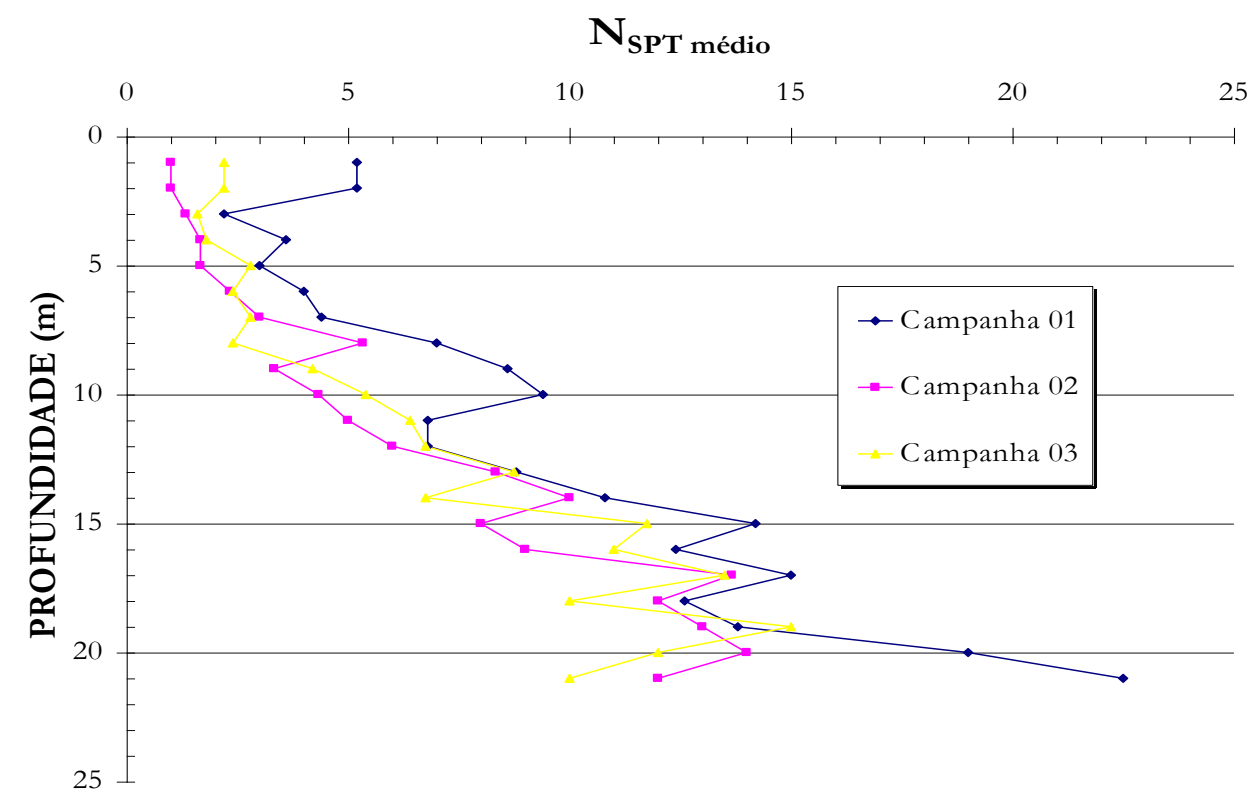

FIGURA 3.3: Variação do $\mathrm{N}_{\mathrm{SPT}}$ médio em função da profundidade para cada campanha de sondagem realizada (SANTOS, 2001).

Da mesma forma ocorreu no caso das campanhas de CPT. Plotando-se o gráfico dos valores médios de $\mathrm{q}_{\mathrm{c}}$ e $\mathrm{f}_{\mathrm{s}}$, de cada campanha, contra a profundidade (Figura 3.4) e comparando-os, percebe-se uma grande variabilidade dos resultados em função dos mesmos motivos já anteriormente mencionados para as campanhas de SPT. 
$\mathrm{q}_{\mathrm{c}}$ e $\mathrm{f}_{\mathrm{s}}(\mathrm{MPa})$

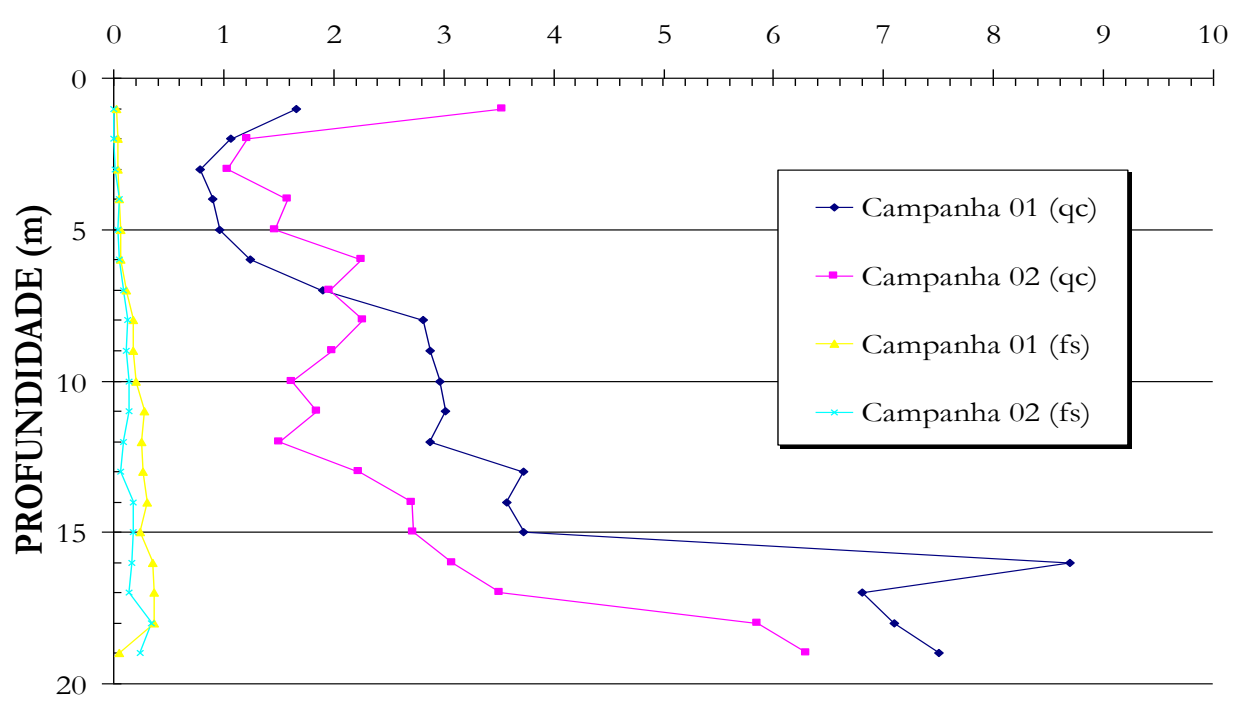

FIGURA 3.4: Variação das resistências unitárias médias $\left(\mathrm{q}_{\mathrm{c}}\right.$ e $\left.\mathrm{f}_{\mathrm{s}}\right)$ em função da profundidade para cada campanha de sondagem realizada (SANTOS, 2001).

\subsection{2) Ensaios de laboratório}

MACHADO (1998) realizou ensaios de laboratório em amostras indeformadas extraídas de um poço com diâmetro de $1,20 \mathrm{~m}$, a cada metro, até uma profundidade de aproximadamente $10,0 \mathrm{~m}$. Para todas as amostras retiradas realizaram-se ensaios de caracterização, ensaios de compressão confinada convencional saturada e com controle de sucção, triaxiais convencionais saturados e com sucção controlada.

As Tabelas 3.1 a 3.3 e Figura 3.5 apresentam as características e índices físicos representativos do maciço de solos do Campo Experimental de Fundações da USP/SC. 


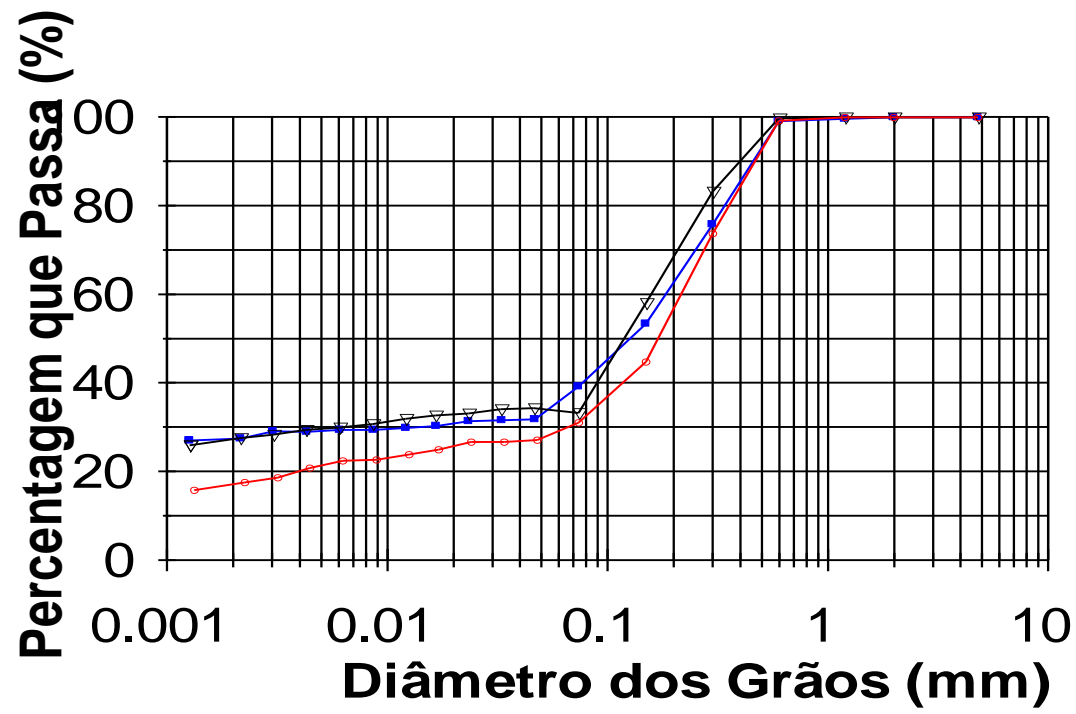

$--3,0 m-5,0 m-8,0 m$

FIGURA 3.5: Curvas granulométricas obtidas para as profundidades de 3,5 e 8m (MACHADO, 1998).

TABELA 3.1: Frações granulométricas constituintes dos solos (MACHADO, 1998).

\begin{tabular}{cccc}
\hline Prof. (m) & Areia (\%) & Silte (\%) & Argila (\%) \\
\hline $3 \mathrm{~m}$ & 60,8 & 11,9 & 27,3 \\
$5 \mathrm{~m}$ & 66,7 & 5,90 & 27,4 \\
$8 \mathrm{~m}$ & 68,9 & 13,7 & 17,4 \\
\hline
\end{tabular}

TABELA 3.2: Valores de peso específico seco e teor de umidade obtidos ao longo do perfil de coleta de blocos indeformados (MACHADO, 1998).

\begin{tabular}{cccccccccc}
\hline & 1 & 2 & 3 & 4 & 5 & 6 & 7 & 8 & 9 \\
\hline $\mathrm{w}(\%)$ & 13,7 & 14,6 & 15,8 & 16,8 & 16,4 & 17,2 & 19,1 & 16,7 & 18,3 \\
$\gamma_{\mathrm{d}}\left(\mathrm{kN} / \mathrm{m}^{3}\right)$ & 12,5 & 13,6 & 13,8 & 14,3 & 14,4 & 14,7 & 15,2 & 16,1 & 16,6 \\
$\gamma\left(\mathrm{kN} / \mathrm{m}^{3}\right)$ & 14,2 & 15,6 & 16,0 & 16,7 & 14,8 & 17,1 & 18,1 & 18,8 & 19,6 \\
$\mathrm{e}$ & 1,17 & 0,99 & 0,96 & 0,90 & 0,88 & 0,84 & 0,78 & 0,68 & 0,63 \\
\hline
\end{tabular}


TABELA 3.3: Resultados dos ensaios de caracterização e compactação (MACHADO, 1998).

\begin{tabular}{cccccc}
\hline Prof. $(\mathrm{m})$ & $\gamma_{\mathrm{dmax}}\left(\mathrm{kN} / \mathrm{m}^{3}\right)$ & $\mathrm{w}_{\mathrm{ot}}(\%)$ & $\mathrm{w}_{\mathrm{L}}(\%)$ & $\mathrm{w}_{\mathrm{P}}(\%)$ & $\gamma_{\mathrm{s}}\left(\mathrm{kN} / \mathrm{m}^{3}\right)$ \\
\hline $3 \mathrm{~m}$ & 18,7 & 14,0 & 27,9 & 16,0 & 27,1 \\
$5 \mathrm{~m}$ & 18,4 & 14,8 & 30,9 & 19,8 & 27,5 \\
$8 \mathrm{~m}$ & 18,9 & 11,2 & 28,4 & 17,2 & 27,1 \\
\hline
\end{tabular}

\section{2) Variabilidade do maciço de solos}

AOKI (2000) analisou a variabilidade do maciço de solos associando os valores de $\mathrm{N}_{\mathrm{SPT}}$, para diferentes furos em diferentes profundidades, com a litologia do local, para as três campanhas de sondagem à percussão (figuras 3.6 a $3.8)$.

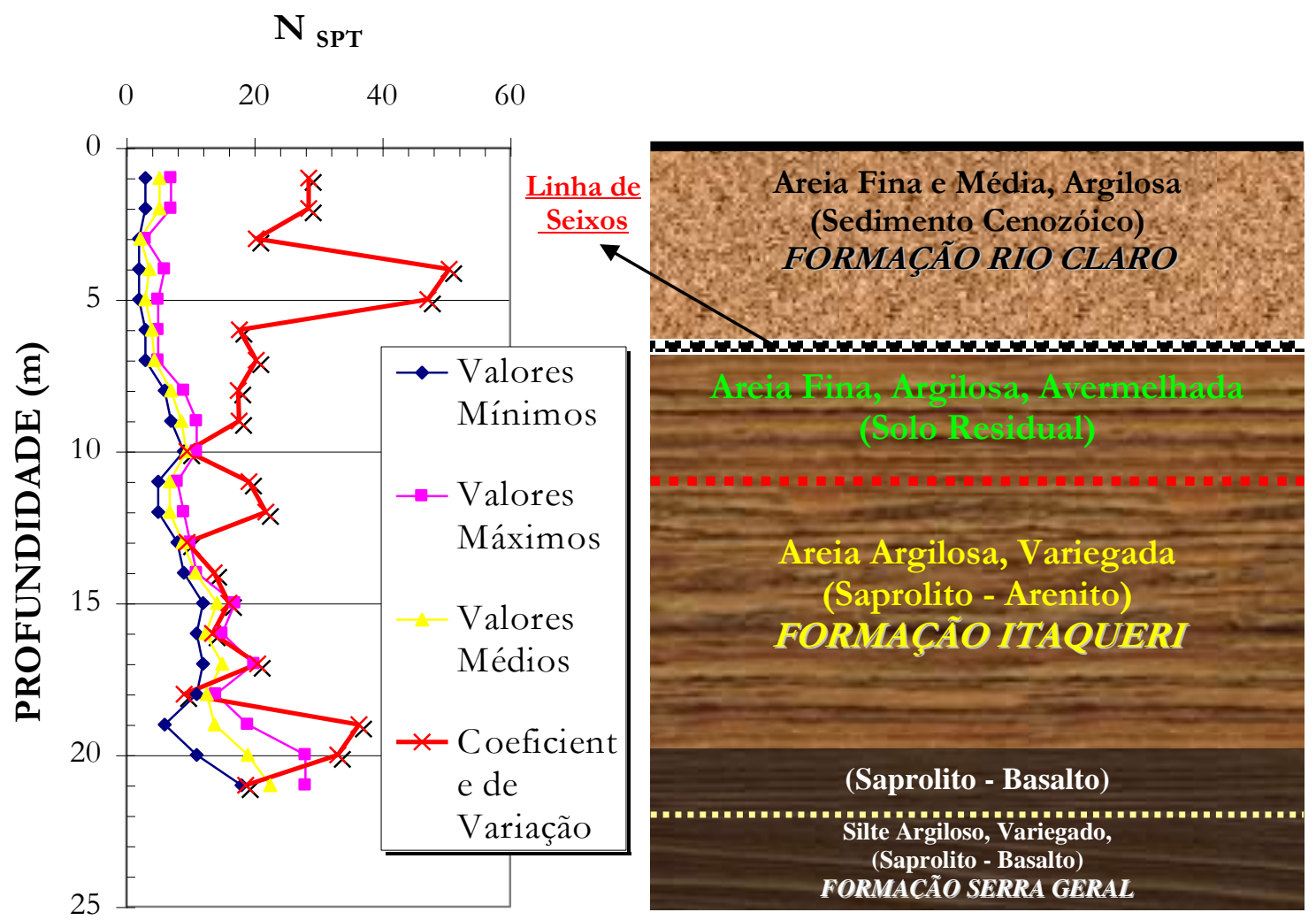

FIGURA 3.6: Variabilidade do maciço de solos em função do $\mathrm{N}_{\text {SPT }}$ e litologia para a $1^{\text {a }}$ campanha de sondagem à percussão (AOKI, 2000 apud SANTOS, 2001). 


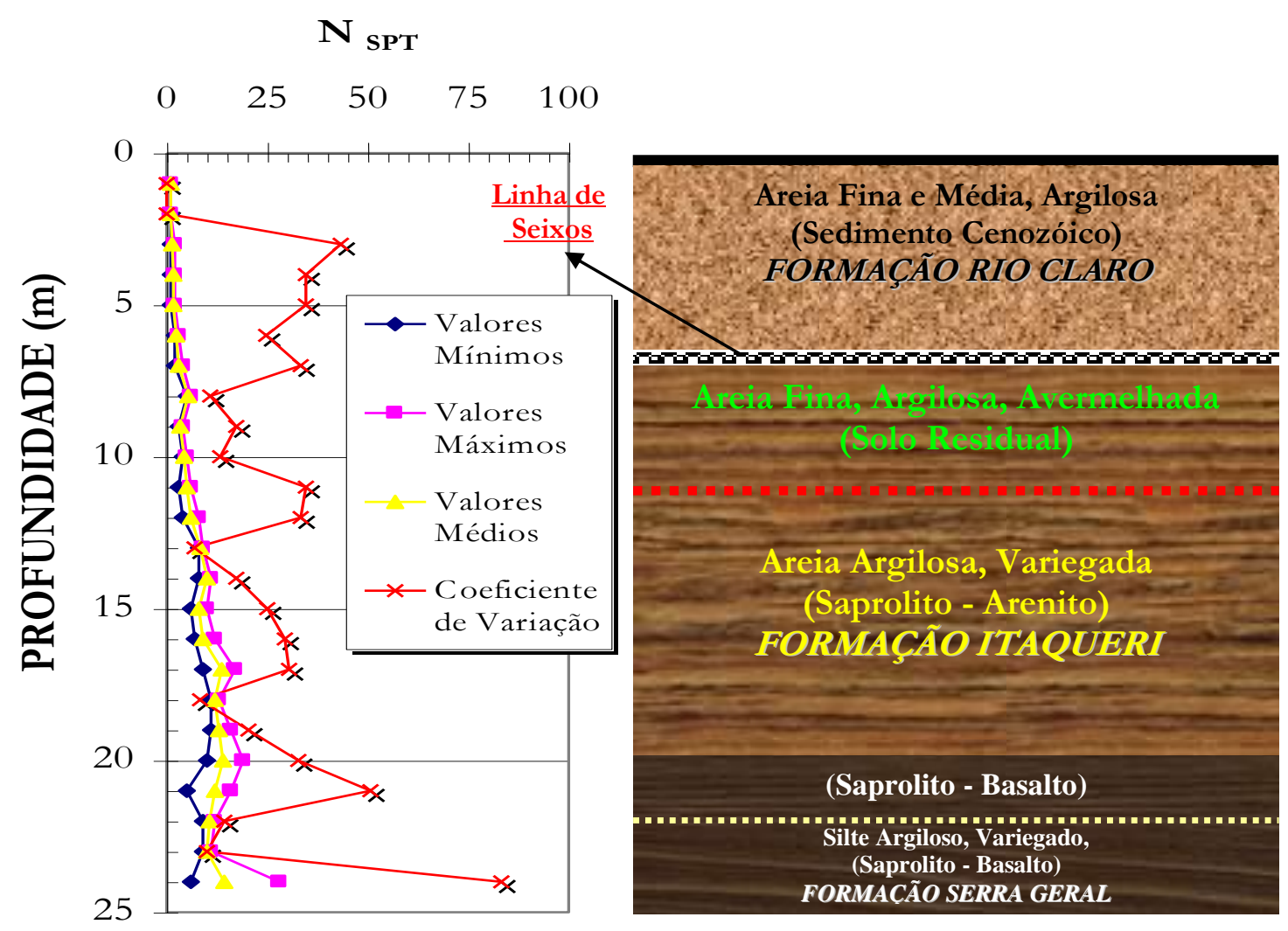

FIGURA 3.7: Variabilidade do Maciço de solos em função do $\mathrm{N}_{\mathrm{SPT}} \mathrm{e}$ litologia para a $2^{\mathrm{a}}$ campanha de sondagem à percussão (AOKI, 2000 apud SANTOS, 2001). 


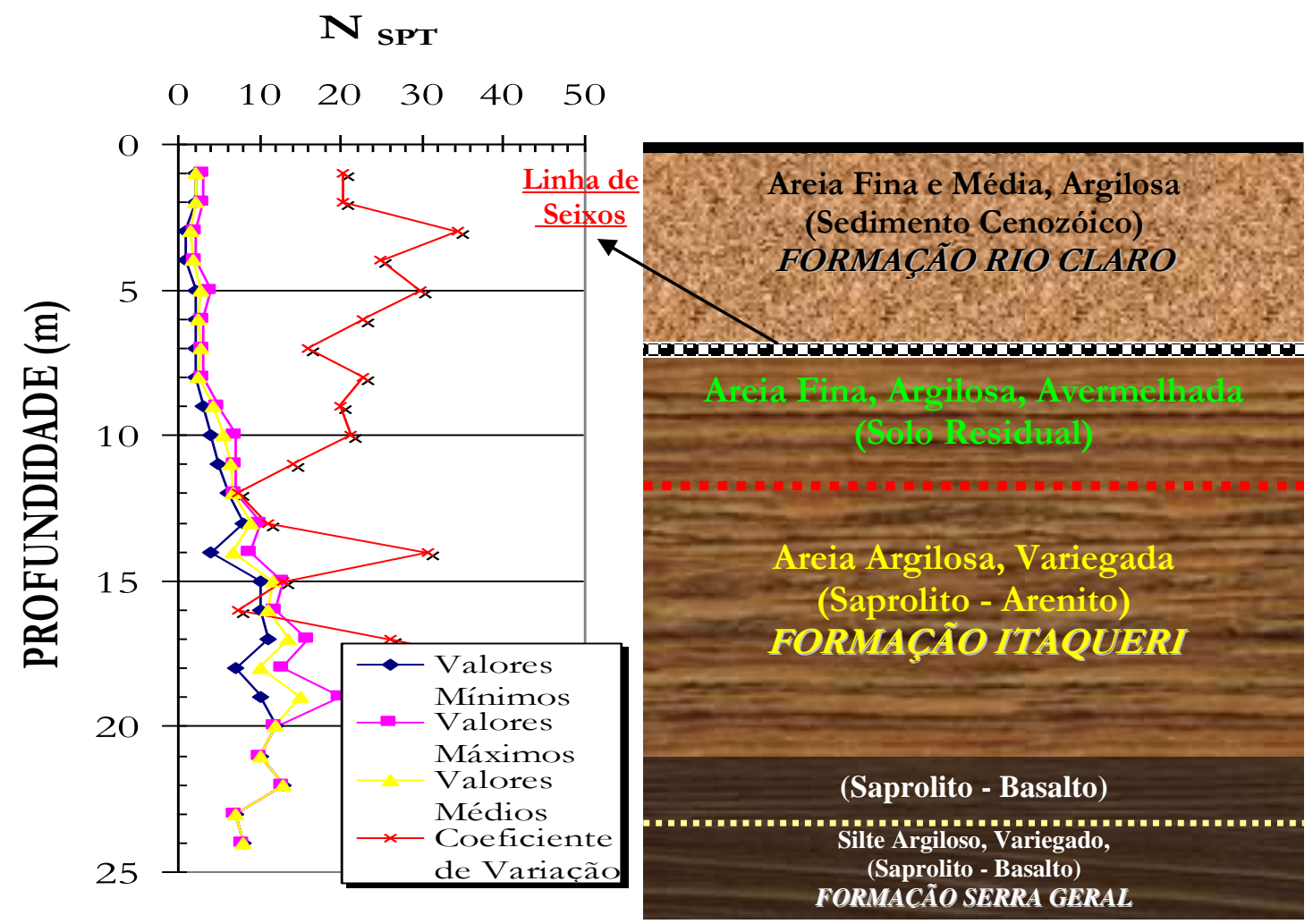

FIGURA 3.8: Variabilidade do maciço de solos em função do $\mathrm{N}_{\mathrm{SPT}} \mathrm{e}$ litologia para a $3^{\text {a }}$ campanha de sondagem à percussão (AOKI, 2000 apud SANTOS, 2001).

AOKI (2000) conclui que o maciço de solos em questão apresenta quatro unidades de formação geológica:

- Formação Rio Claro, constituída por areia fina e média, argilosa pouco compacta e muito porosa, possuindo uma característica um pouco mais homogênea (coeficiente de variação entre 20 e $25 \%$ ). Tal variabilidade é função da própria variação da pressão de sucção com a profundidade, já que esta camada encontra-se acima do nível d'água.

- Formação Itaqueri, encontrada abaixo da linha de seixos e dividida em duas subcamadas: uma de solo residual, apresentando pouca variação (em torno de $25 \%$, e constante com profundidade) e outra de um saprolito de arenito que possui características bem mais heterogêneas, principalmente, devido ao grau de alteração da rocha, gerando assim uma grande variabilidade. 
- Formação Serra Geral, encontrada na porção inferior, no contato com uma alteração de basalto. Possui uma certa importância já que ainda pode ser perfurada e amostrada em certos pontos em função do manto de intemperismo existente e da sua própria geometria.

- Formação Botucatu, localizada abaixo da Formação Serra Geral, não podendo ser perfurada por sondagem à percussão. 


\section{4 - MATERIAIS E MÉTODOS}

\section{1 - Provas de carga em placa}

Foram realizadas onze provas de carga em placa circular de $0,80 \mathrm{~m}$ de diâmetro, assente no terreno a 1,5 , 4,0 , 6,0 e 8,0m de profundidade. Esses ensaios foram executados em quatro cavas abertas no Campo Experimental, com diâmetro de 1,0 m, de acordo com o esquema de locação da figura 4.1. Outras quatro cavas foram utilizadas por COSTA (1999). Em quatro dos onze ensaios o terreno foi préinundado por $48 \mathrm{~h}$, pelo menos. A inundação deu-se através de água potável proveniente do poço profundo da EESC, com o cuidado de manter uma lâmina d'água mínima de $5 \mathrm{~cm}$ no fundo da cava.

Nos demais sete ensaios, realizados sem inundação do terreno obtevese a sucção média sob a placa através de tensiômetros instalados na cava e procedeuse a determinação do teor de umidade do solo em amostras deformadas.

As provas de carga foram do tipo rápido, em estágios de 15 minutos com leituras de recalque feitas nos tempos de $0,1,2,3,6,9,12$ e 15 minutos. $\mathrm{Na}$ maioria dos ensaios o descarregamento foi realizado em três estágios.

A tabela 4.1 indica algumas características da realização das provas de carga. 


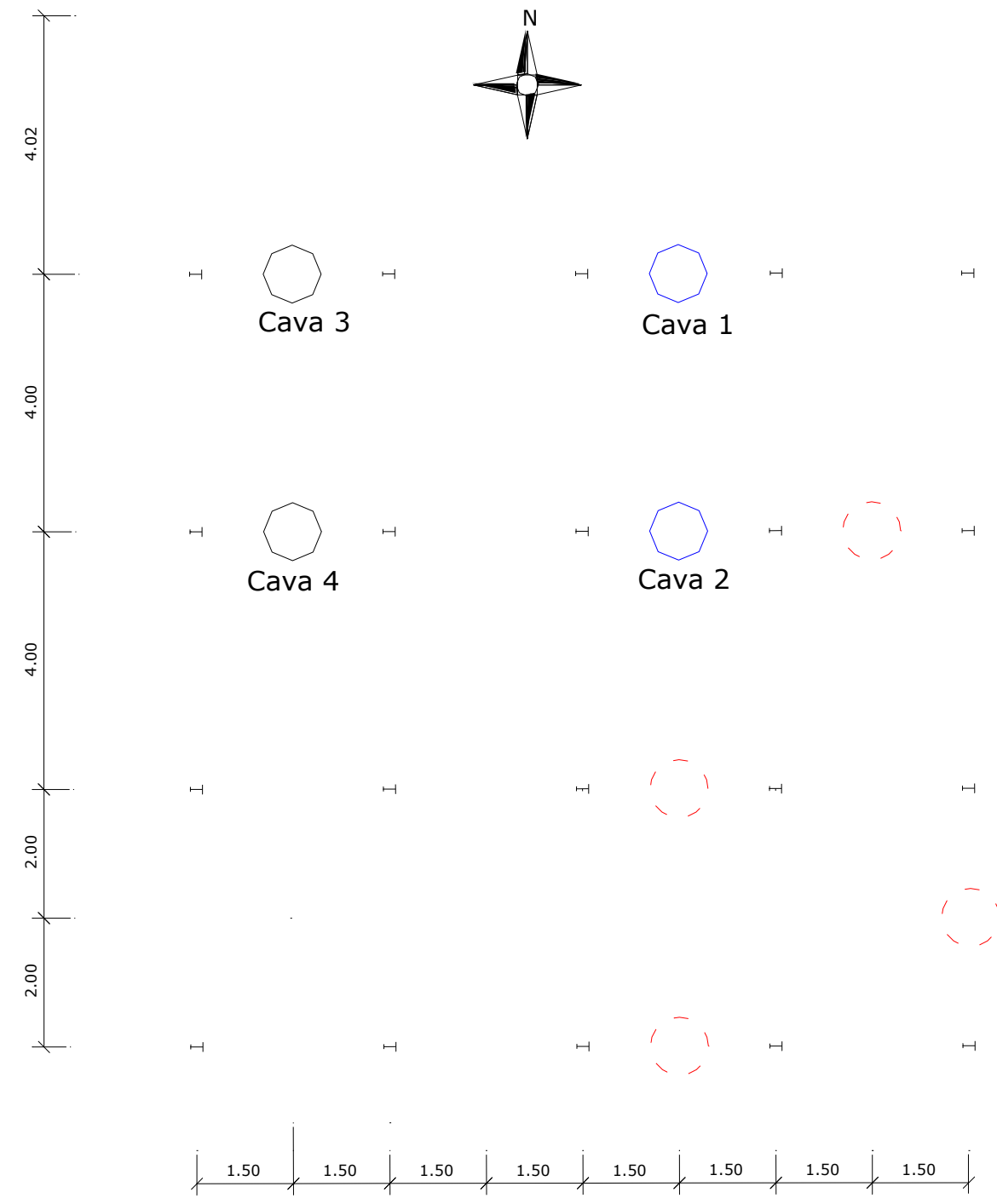

FIGURA 4.1: Locação das cavas para os ensaios de placa 
Tabela 4.1: Características das provas de carga.

\begin{tabular}{|l|c|c|c|}
\hline \multicolumn{1}{|c|}{ Ensaio } & Prof. (m) & Inundação & Data \\
\hline N1C3 & 1,5 & Não & $24 / 06 / 00$ \\
\hline N4C1 & 4,0 & Não & $12 / 05 / 00$ \\
\hline N4C2 & 4,0 & Não & $13 / 06 / 00$ \\
\hline S4C3 & 4,0 & Sim & $01 / 07 / 00$ \\
\hline S4C4 & 4,0 & Sim & $18 / 07 / 00$ \\
\hline N6C1 & 6,0 & Não & $20 / 05 / 00$ \\
\hline N6C2 & 6,0 & Não & $17 / 06 / 00$ \\
\hline S6C3 & 6,0 & Sim & $08 / 07 / 00$ \\
\hline S6C4 & 6,0 & Sim & $24 / 07 / 00$ \\
\hline N8C1 & 8,0 & Não & $28 / 05 / 00$ \\
\hline N8C2 & 6,0 & Não & $22 / 06 / 00$ \\
\hline
\end{tabular}

\section{2 - Equipamentos e materiais}

\section{Barraca de proteção}

Para proteção do local de realização dos ensaios, utilizou-se uma barraca construída em módulos, com perfis metálicos, fechamento lateral de madeirit e cobertura com lona.

\section{Placas}

Para a profundidade de $1,5 \mathrm{~m}$, a placa utilizada possui formato circular com 0,80 m de diâmetro e espessura de $25 \mathrm{~mm}$, resultando uma área de 0,50 m2. Para aumentar sua rigidez, em sua parte superior foi soldada uma chapa circular com $25 \mathrm{~mm}$ de espessura e $0,30 \mathrm{~m}$ de diâmetro, resultando uma massa total de $105 \mathrm{~kg}$. 
Já para profundidades maiores, a placa utilizada é constituída por chapa de ferro fundido de $12,7 \mathrm{~mm}$ de espessura e também possui formato circular com 0,80 m de diâmetro. Para garantir sua rigidez, soldou-se na sua parte superior uma outra chapa de ferro fundido de $0,60 \mathrm{~m}$ de diâmetro e espessura de $12,7 \mathrm{~mm}$, resultando uma massa total de $79 \mathrm{~kg}$.

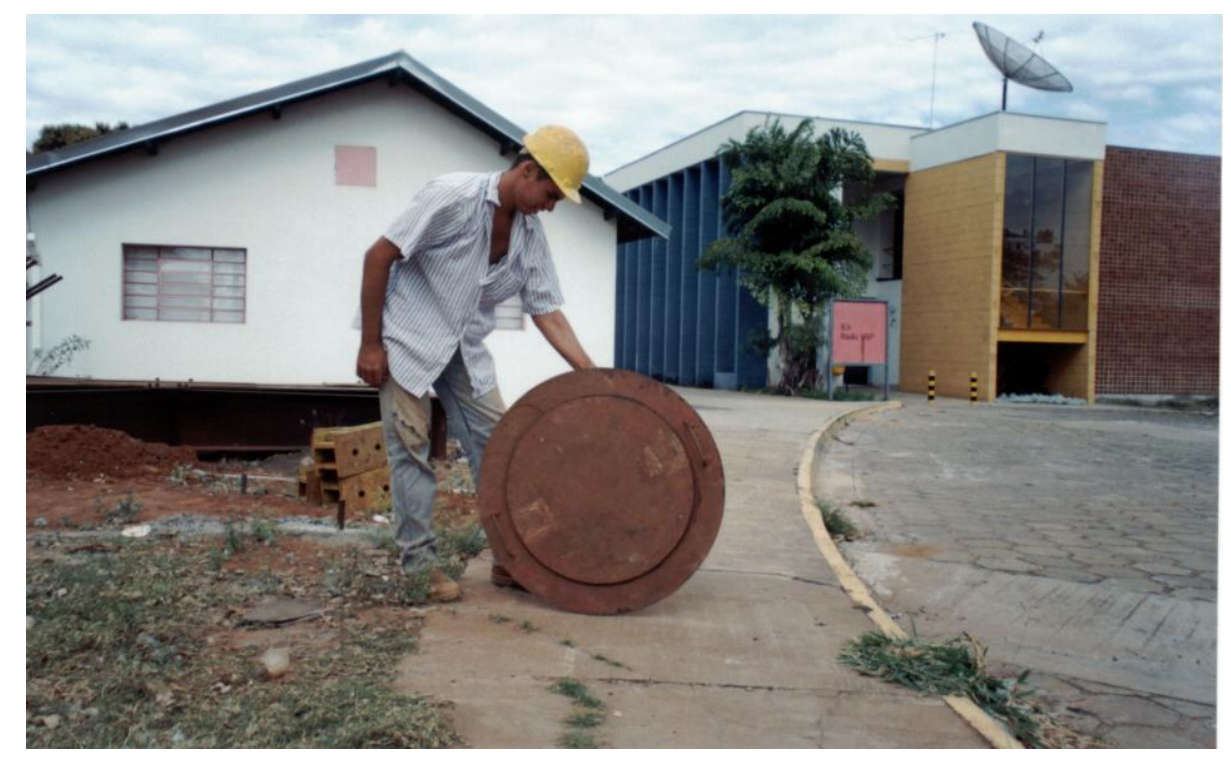

FOTO 01: Placa utilizada para profundidades maiores que $2 \mathrm{~m}$.

\section{Macaco hidráulico e bomba}

Para a execução das provas de carga utilizaram-se dois macacos hidráulicos , um com capacidade de $200 \mathrm{kN}$ para as cotas -1,5 , -4,0 , -6,0 m e outro com capacidade de $500 \mathrm{kN}$ para a cota de $-8,0 \mathrm{~m}$, ambos acionados através de bomba elétrica.

\section{Célula de carga}

As células de carga utilizadas possuem capacidade de carga de 200 e $500 \mathrm{kN}$ e antes de serem utilizadas nas provas de carga foram devidamente calibradas em laboratório. As curvas de calibração encontram-se nos anexos A e B. 


\section{Sistema de leitura}

Foi utilizado um indicador de deformações da marca Transdutec, modelo T832, com resolução de $1 \mu$ strain para as leituras de deformações específicas dos "strain-gages" instalados na célula de carga.

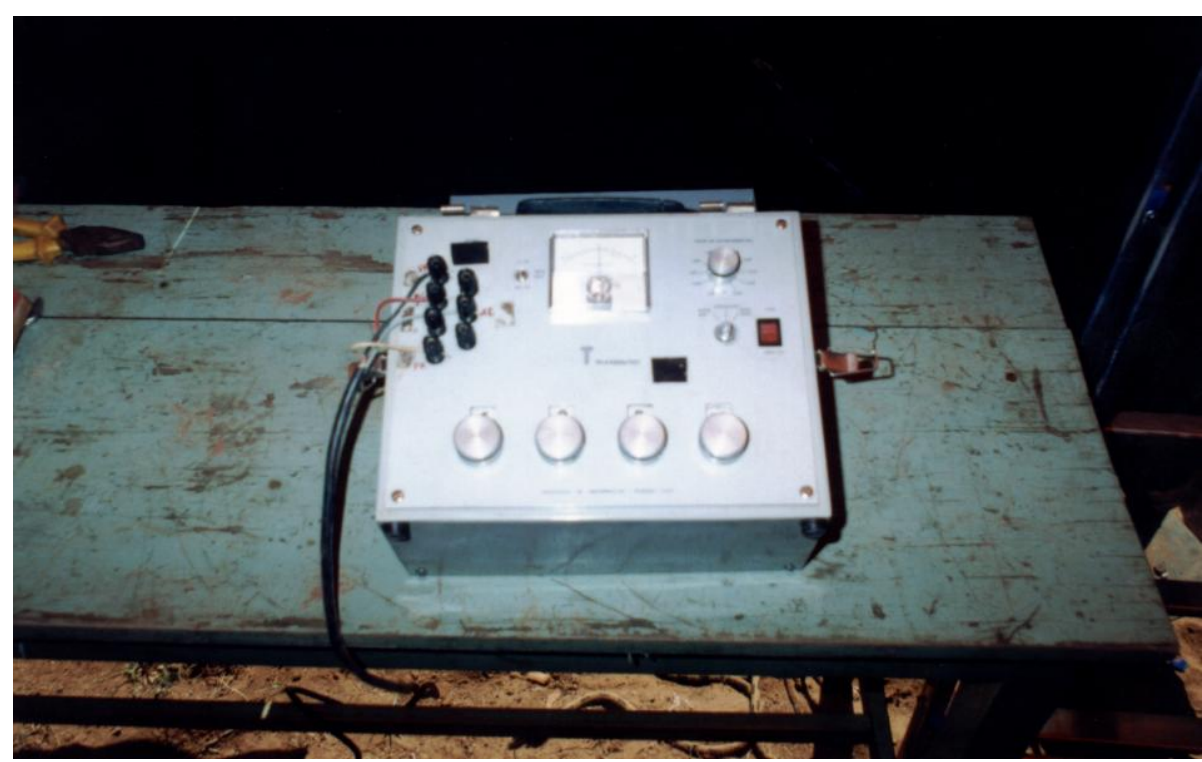

FOTO 02: Detalhe do indicador de deformações.

\section{Extensômetros}

Em cada prova de carga utilizaram-se quatro extensômetros mecânicos da marca Mitutoyo, com resolução de 0,01 mm e curso total de $50 \mathrm{~mm}$, para as medidas de recalque. Para sua fixação nas guias de referência utilizaram-se bases magnéticas articuláveis.

\section{Guias de referências}

Duas vigas de aço com perfil em $\mathrm{U}$ e com 3,30 m de comprimento foram utilizadas como guias de referência para as medidas de recalque. Essas guias 
eram parafusadas em pontaletes de ferro previamente cravados no solo, para que a rigidez do sistema de referência fosse garantida.

\section{Torres de transferência de carga}

Para transferir a carga aplicada pelo macaco hidráulico, situado na superfície, até a placa, utilizaram-se torres de aço.

Para a profundidade de ensaio de 1,5 $\mathrm{m}$ a torre utilizada é composta de um cilindro de 1,53 $\mathrm{m}$ de comprimento, $0,17 \mathrm{~m}$ de diâmetro externo e parede de 10 $\mathrm{mm}$ de espessura, possuindo $80 \mathrm{~kg}$ de massa.

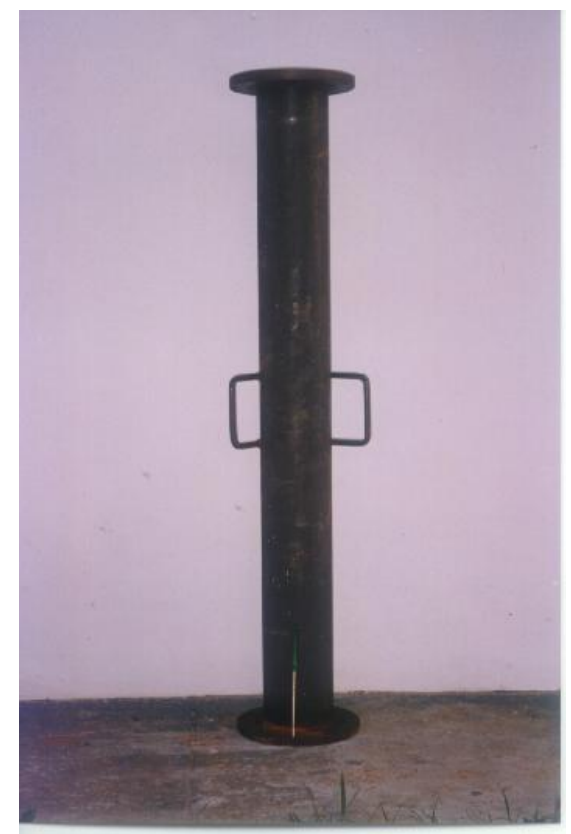

FOTO 03: Detalhe da torre de transferência de carga utilizada para a profundidade de $1,5 \mathrm{~m}$.

Para as profundidades maiores utilizou-se uma torre metálica, composta por módulos de 2,0 m de comprimento, com seção de 0,28 x 0,28 m2. Os módulos foram interligados com 4 parafusos de aço de 50,8 $\mathrm{mm}$ x 12,7 $\mathrm{mm}$. 
Cada módulo foi construído com perfis de $31,8 \mathrm{~mm}$ x 6,4 $\mathrm{mm}$, para as longarinas, 25,4 mm x 4,8 mm, para as transversinas, resultando $119 \mathrm{~kg}$ de massa para o módulo de $2,0 \mathrm{~m}$.

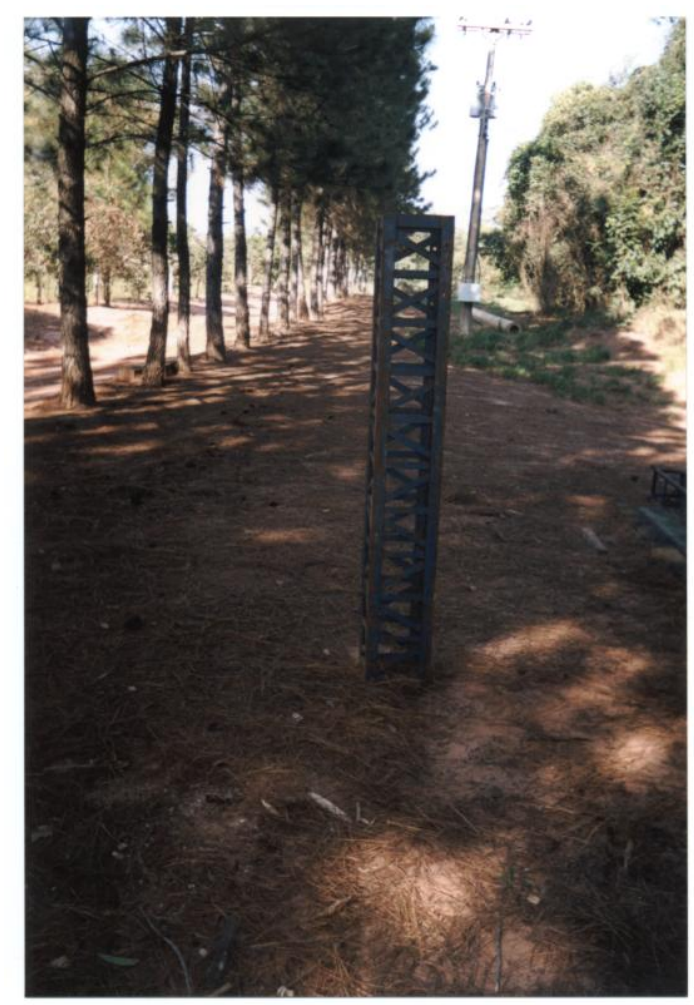

FOTO 04: Detalhe da torre de transferência de carga utilizada para as profundidades de 4,0, 6,0 e 8,0 m.

\section{Hastes para medidas de recalque}

Para a profundidade de $1,5 \mathrm{~m}$, barras de aço com rosca, do tipo Dywidag de $32 \mathrm{~mm}$ de diâmetro, foram utilizadas para que os extensômetros fossem instalados acima da superfície do terreno. Essas hastes eram rosqueadas em luvas de aço previamente soldadas na placa.

Para profundidades maiores, utilizaram-se hastes de alumínio de 25 $\mathrm{mm}$ de diâmetro, sendo que sua fixação foi feita mediante o emprego de alças que 
mantém a haste livre para acompanhar o recalque da placa. A haste foi simplesmente apoiada sobre a placa.

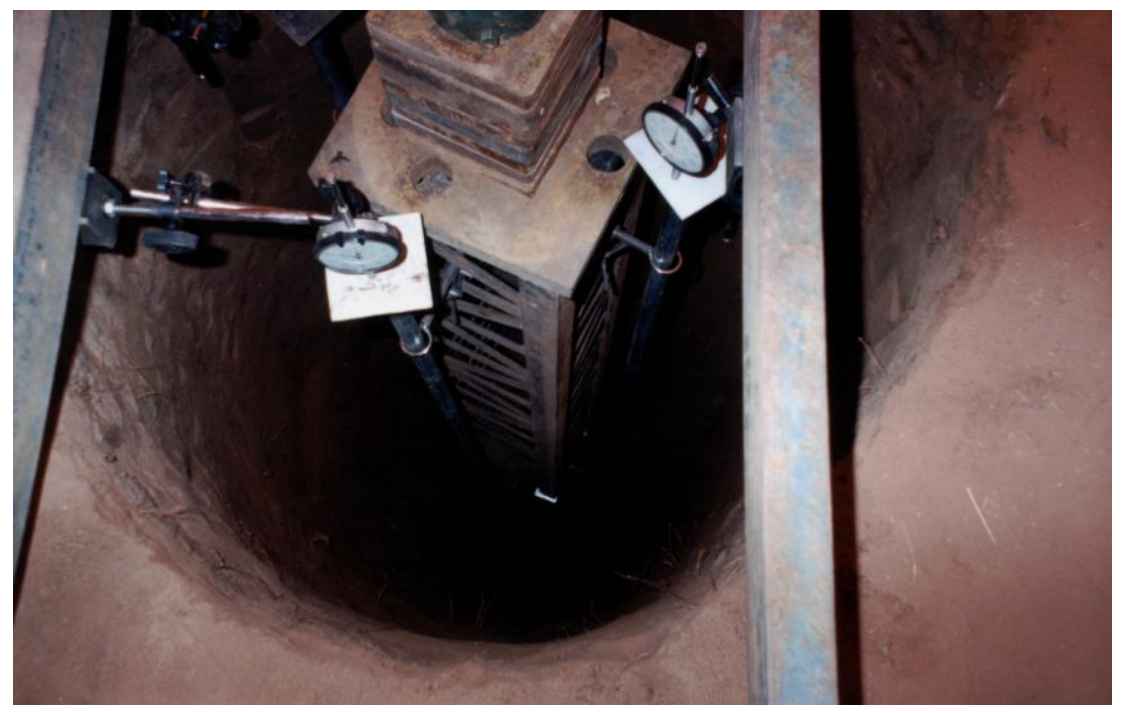

FOTO 05: Detalhe das hastes para medidas de recalque.

\section{Rótula}

Com o objetivo de anular qualquer excentricidade do mecanismo de aplicação de carga uma rótula foi inserida entre a célula de carga e a viga de reação.

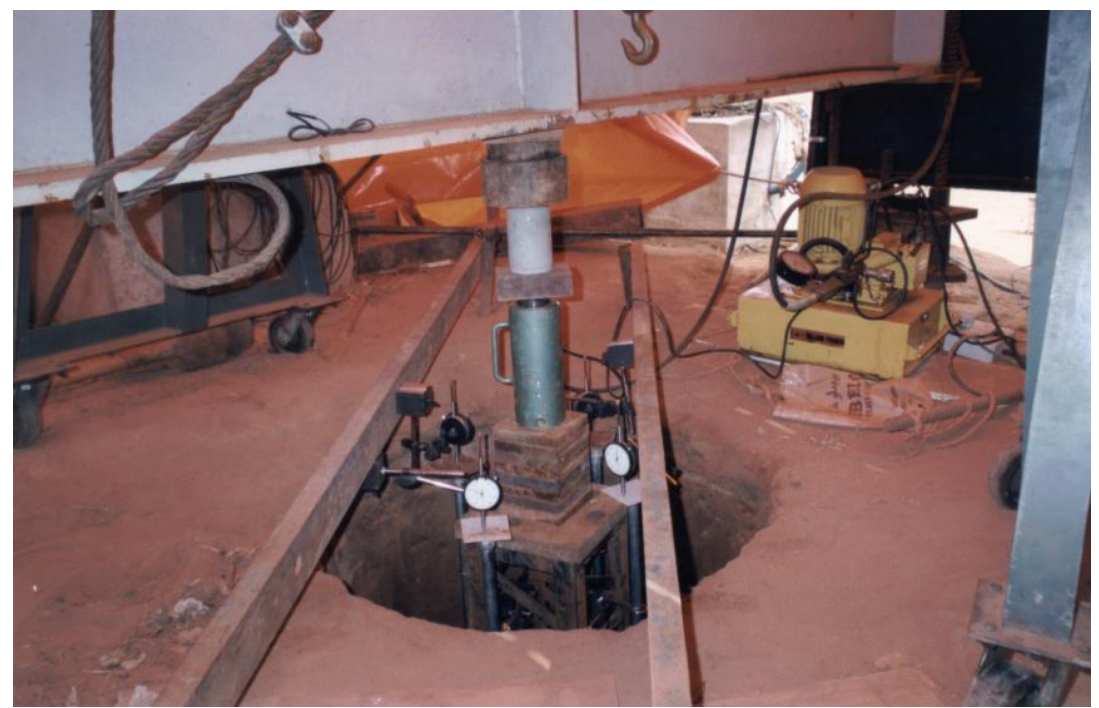

FOTO 06: Detalhe da bomba elétrica, macaco hidráulico, célula de carga e rótula. 


\section{Pórtico para serviços diversos}

Para o manuseio dos equipamentos mais pesados utilizou-se um sistema de roldanas, deslizante em pórtico sobre rodas.

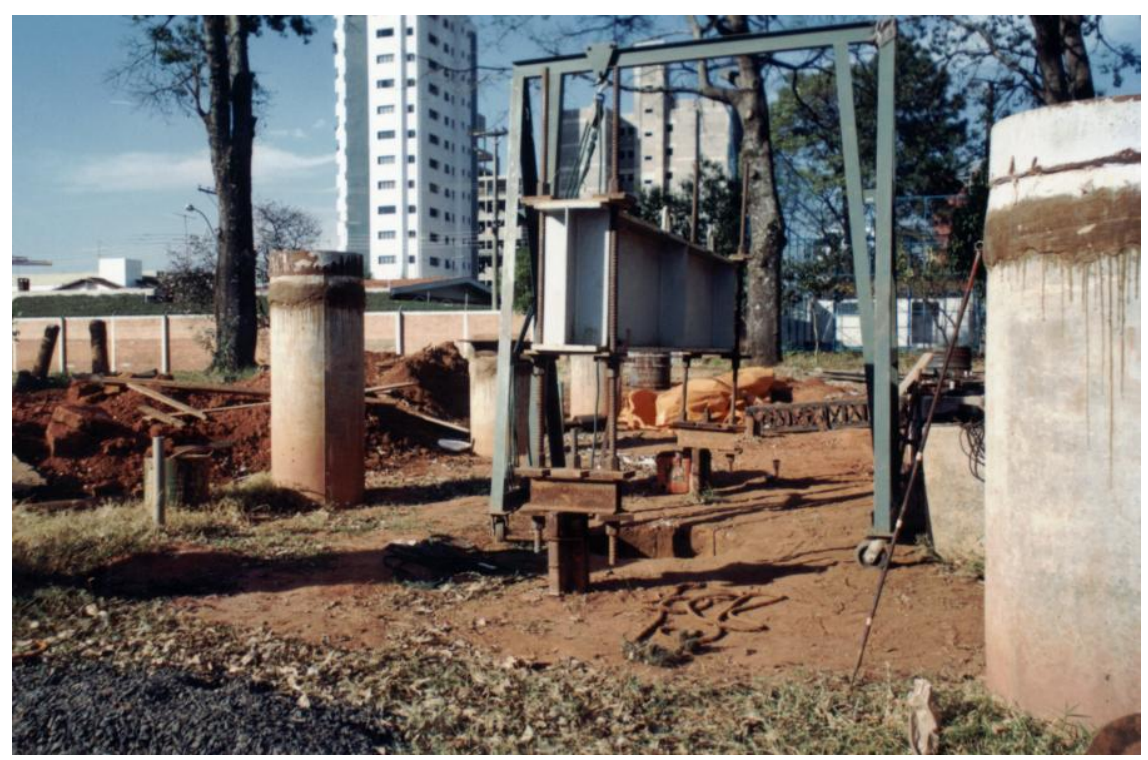

FOTO 07: Detalhe do pórtico utilizado para serviços diversos.

\section{3 - Sistema de reação}

Para o sistema de reação utilizou-se uma viga metálica de elevada rigidez, com seção transversal em “ I " com 0,30 x 0,65 m, comprimento de 3,30 m, capacidade de suporte de $800 \mathrm{kN}$ e massa de $800 \mathrm{~kg}$. Em cada extremidade da viga havia uma composição de barras de aço do tipo Dywidag de $32 \mathrm{~mm}$ de diâmetro.

As estacas de reação eram metálicas, do tipo trilho TR-68, com $27 \mathrm{~m}$ de comprimento e carga admissível à tração de $550 \mathrm{kN}$. O esquema de montagem dos ensaios pode ser observado na figura 4.2. 


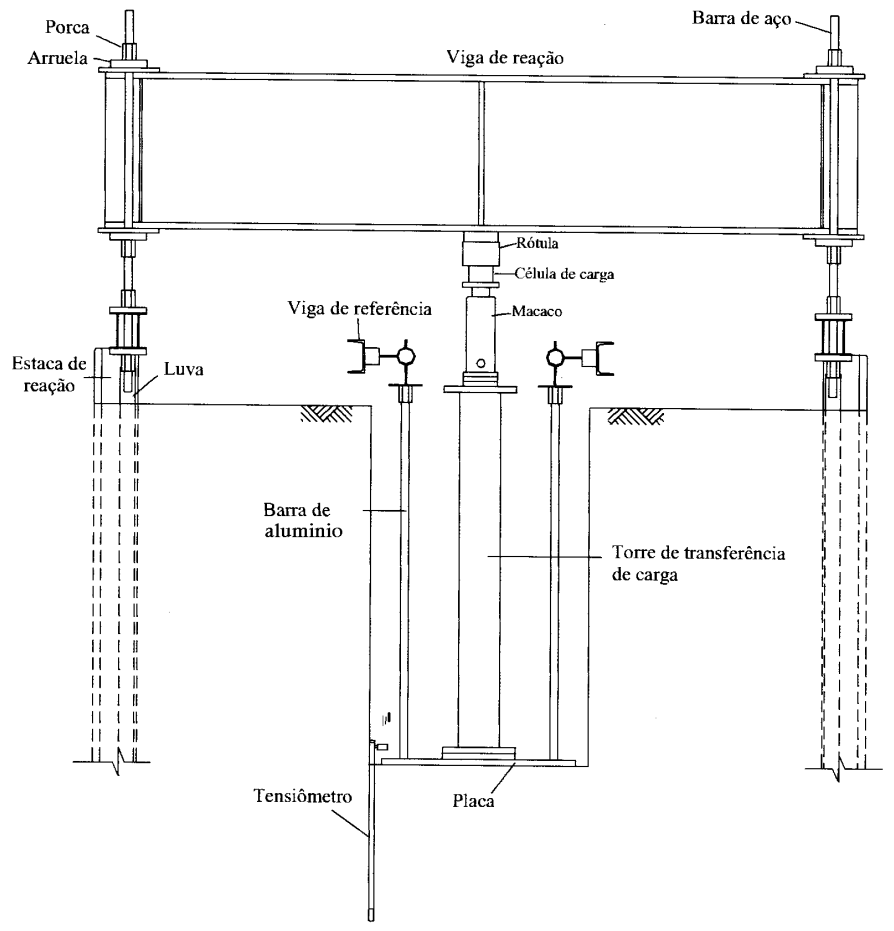

a) Corte longitudinal

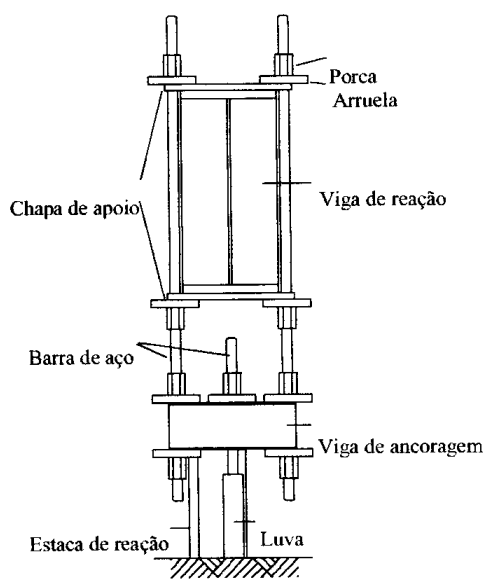

b) Corte transversal

Figura 4.2: Esquema de montagem das provas de carga. 


\section{4 - Medidas de sucção e teor de umidade}

Antes do início dos ensaios não inundados, fazia-se a tradagem no interior da cava para coleta de amostras deformadas nas profundidades $0,10 \mathrm{~m}$, 0,30m , 0,60m e 0,80m abaixo da cota de assentamento da placa, para a determinação do teor de umidade médio do solo.

Nos ensaios não inundados foram instalados tensiômetros nas profundidades $0,10 \mathrm{~m}, 0,30 \mathrm{~m}, 0,60 \mathrm{~m}$ e $0,80 \mathrm{~m}$ abaixo da cota de assentamento da placa, para determinação da sucção matricial média do solo abaixo da placa. Os tensiômetros, da marca Soil Mosture, possuem medidores de pressão negativa e diâmetro externo de aproximadamente $20 \mathrm{~mm}$, e também um reservatório de água na parte superior, o que facilita a complementação do nível de água, bem como a retirada de bolhas do sistema.

Os tensiômetros foram instalados no mínimo 24 horas antes do início da prova de carga, para que a medida de pressão negativa já estivesse estabilizada para iniciar o ensaio.

Utilizou-se um trado helicoidal de diâmetro ligeiramente inferior ao dos tensiômetros, mas a fase final de instalação se deu por prensagem, garantido dessa forma um melhor contato entre o solo e a pedra porosa do tensiômetro.

Aproveitou-se essa tradagem para a coleta de uma amostra deformada, para a determinação do teor de umidade médio do solo sob a placa. 


\section{5 - APRESENTAÇÃO DOS RESULTADOS}

\section{1 - Sucção matricial}

Antes do início de cada ensaio não inundado, procedeu-se a leitura dos tensiômetros instalados às profundidades de $0,10 \mathrm{~m}, 0,30 \mathrm{~m}, 0,60 \mathrm{~m}$ e $0,80 \mathrm{~m}$ abaixo da cota de assentamento da placa. Os valores de sucção matricial obtidos estão apresentados na tabela 5.1.

Em cada tensiômetro observou-se que a sucção matricial não se alterou durante a realização do ensaio.

TABELA 5.1: Valores da sucção matricial obtidos nas provas de carga.

\begin{tabular}{|c|c|c|c|c|c|}
\hline \multirow{2}{*}{ Ensaio } & \multicolumn{5}{|c|}{ Sucção (kPa) } \\
\cline { 2 - 6 } & $\mathbf{0 , 1 0} \mathbf{~ m}$ & $\mathbf{0 , 3 0} \mathbf{~ m}$ & $\mathbf{0 , 6 0} \mathbf{~ m}$ & $\mathbf{0 , 8 0} \mathbf{~ m}$ & Valor médio \\
\hline N1C3 & 38 & 34 & 27 & -- & 33 \\
\hline N4C1 & 20 & 16 & 18 & -- & 18 \\
\hline N4C2 & 30 & 32 & 25 & 25 & 28 \\
\hline N6C1 & 12 & 12 & 12 & 11 & 12 \\
\hline N6C2 & 16 & 18 & 15 & 13 & 16 \\
\hline N8C1 & 8 & 2 & 2 & -- & 4 \\
\hline N8C2 & -- & 10 & 7 & 2 & 9 \\
\hline
\end{tabular}


Com os dados obtidos em campo foi possível verificar a variação da sucção matricial com a profundidade, como pode ser observado na figura 5.1.

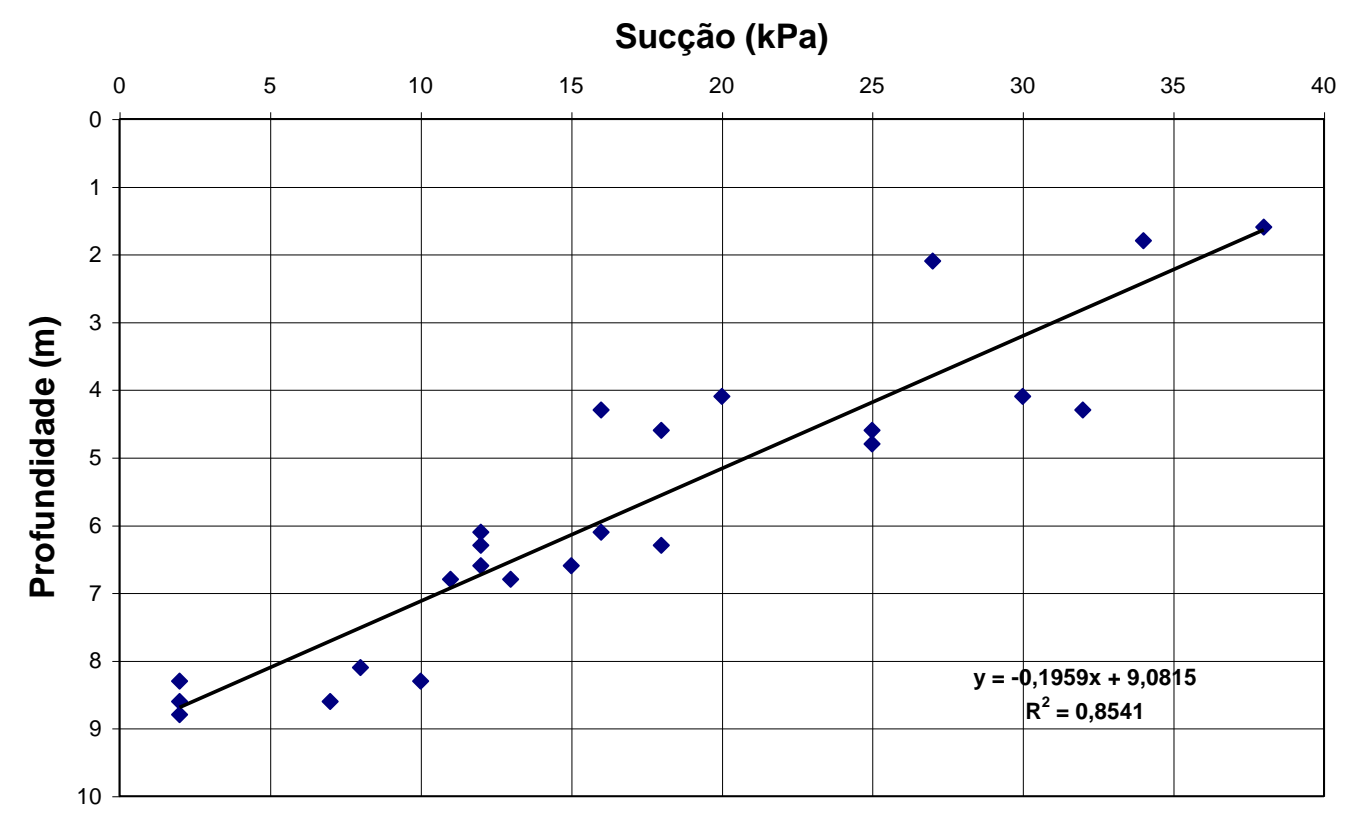

FIGURA 5.1: Variação da sucção matricial com a profundidade.

\section{2 - Teor de umidade}

Das amostras deformadas retiradas durante a instalação dos tensiômetros foram obtidos os valores de teor de umidade gravimétrica apresentados na tabela 5.2. 
TABELA 5.2: Valores do teor de umidade correspondente às provas de carga.

\begin{tabular}{|c|c|c|c|c|c|}
\hline \multirow{2}{*}{ Ensaio } & \multicolumn{6}{|c|}{ Teor de Umidade (\%) } \\
\cline { 2 - 6 } & $\mathbf{0 , 1 0} \mathbf{~ m}$ & $\mathbf{0 , 3 0} \mathbf{~ m}$ & $\mathbf{0 , 6 0} \mathbf{~ m}$ & $\mathbf{0 , 8 0} \mathbf{~ m}$ & Valor médio \\
\hline N1C3 & 11,04 & 12,97 & 14,24 & 13,95 & 13,05 \\
\hline N4C1 & 17,59 & 17,57 & 17,55 & 17,19 & 17,48 \\
\hline N4C2 & 15,53 & 16,07 & 16,20 & 16,37 & 16,04 \\
\hline N6C1 & 18,21 & 18,94 & 18,89 & 18,19 & 18,56 \\
\hline N6C2 & 17,46 & 18,38 & 18,36 & 18,88 & 18,27 \\
\hline N8C1 & 18,20 & 17,87 & 18,42 & 19,65 & 18,54 \\
\hline N8C2 & 16,77 & 17,29 & 17,78 & 18,01 & 17,46 \\
\hline
\end{tabular}

Com os dados obtidos em campo foi possível verificar a variação do teor de umidade com a profundidade, como pode ser observado na figura 5.2.

Teor de Umidade (\%)

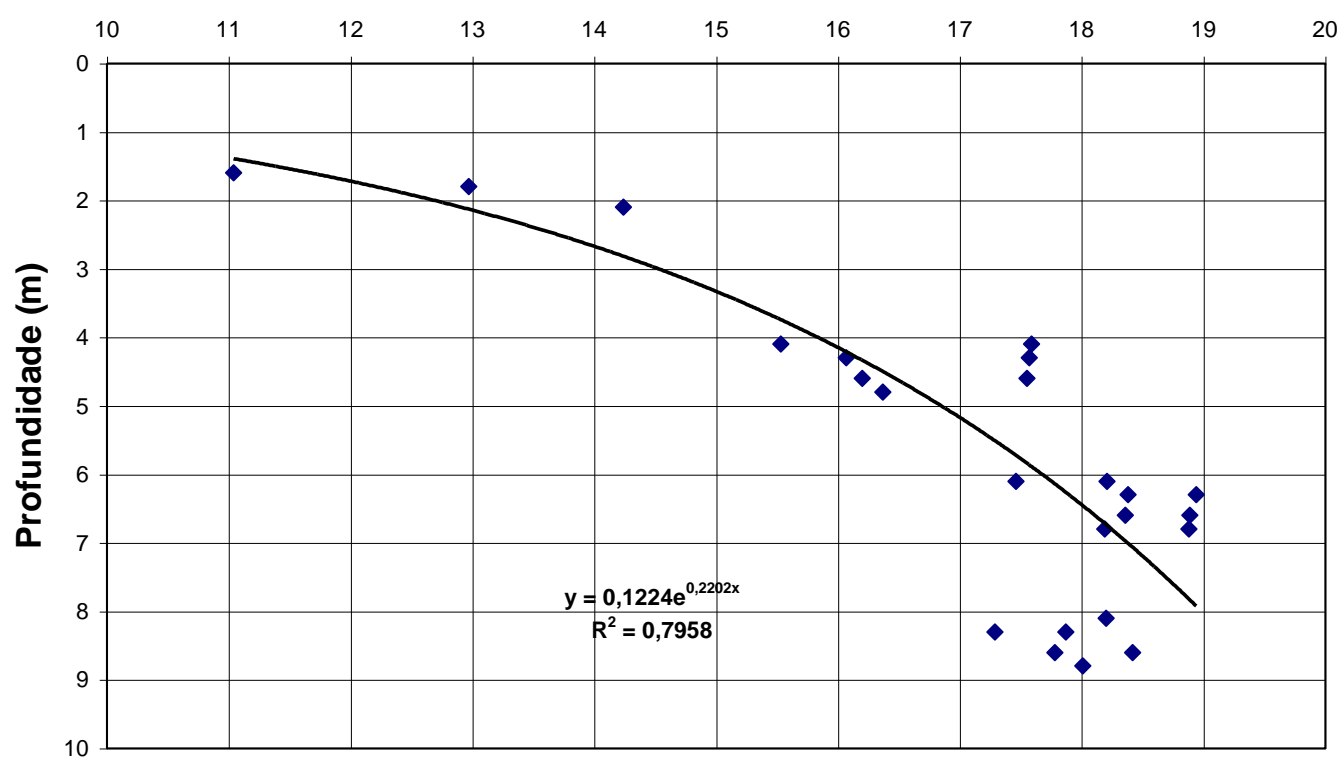

FIGURA 5.2: Variação do teor de umidade com a profundidade. 


\section{3 - Curvas tensão $x$ recalque}

Nas figuras 5.3 a 5.6, estão apresentadas as curvas tensão x recalque obtidas nos ensaios. O valor entre parênteses expressa o valor médio da sucção matricial durante a realização do ensaio.

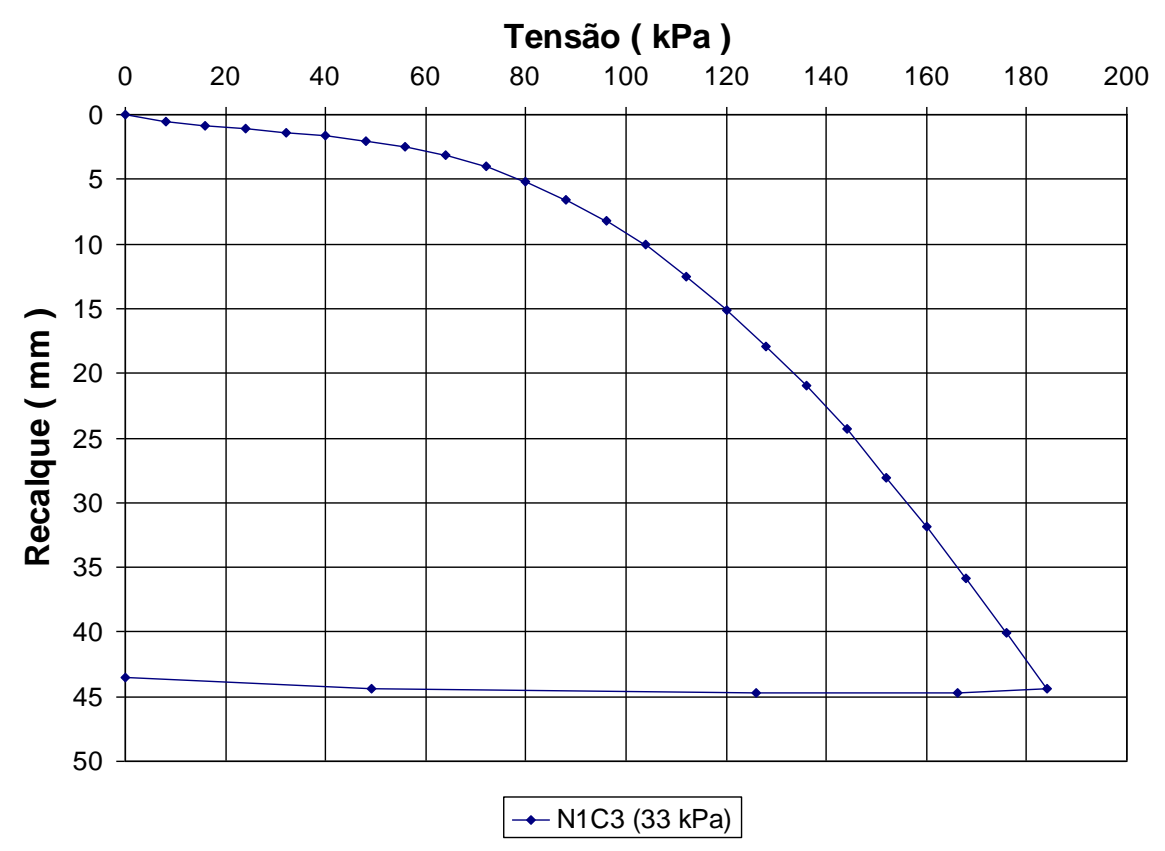

FIGURA 5.3: Curva tensão $x$ recalque para profundidade $1,50 \mathrm{~m}$. 


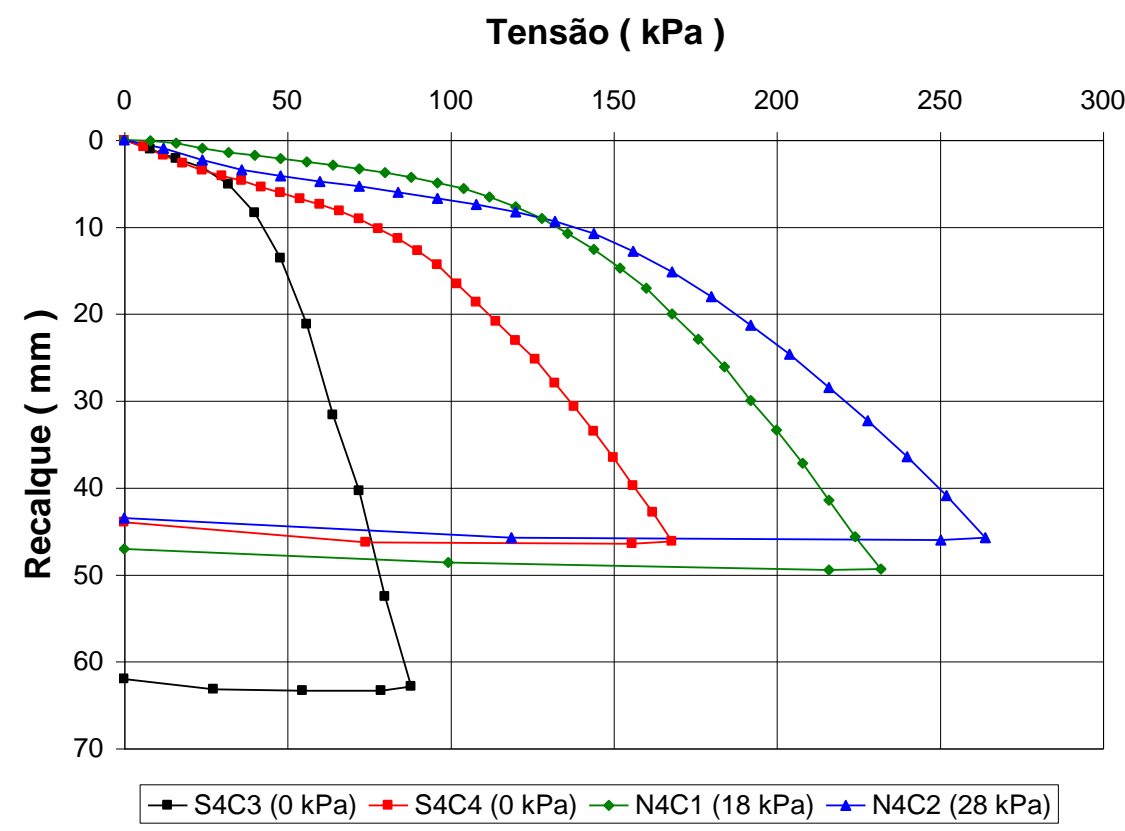

FIGURA 5.4: Curvas tensão x recalque para profundidade de 4,0m.

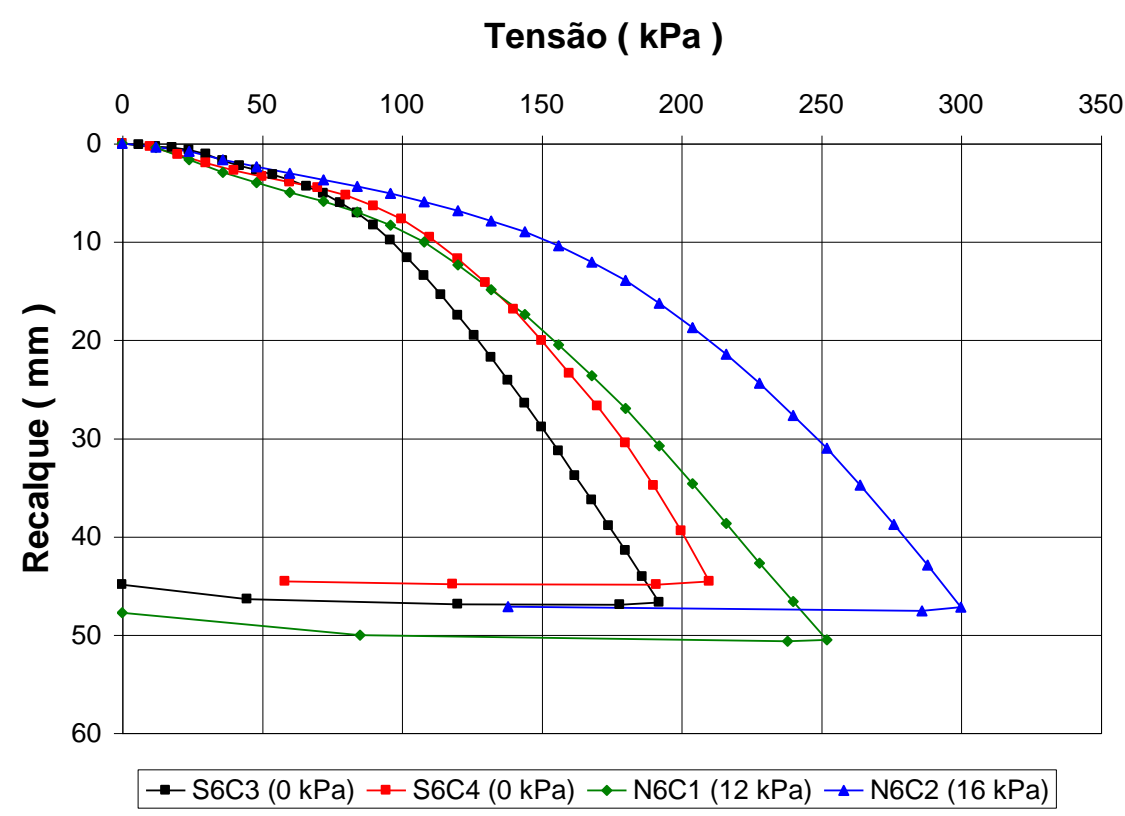

FIGURA 5.5: Curvas tensão $x$ recalque para profundidade de $6,0 \mathrm{~m}$. 


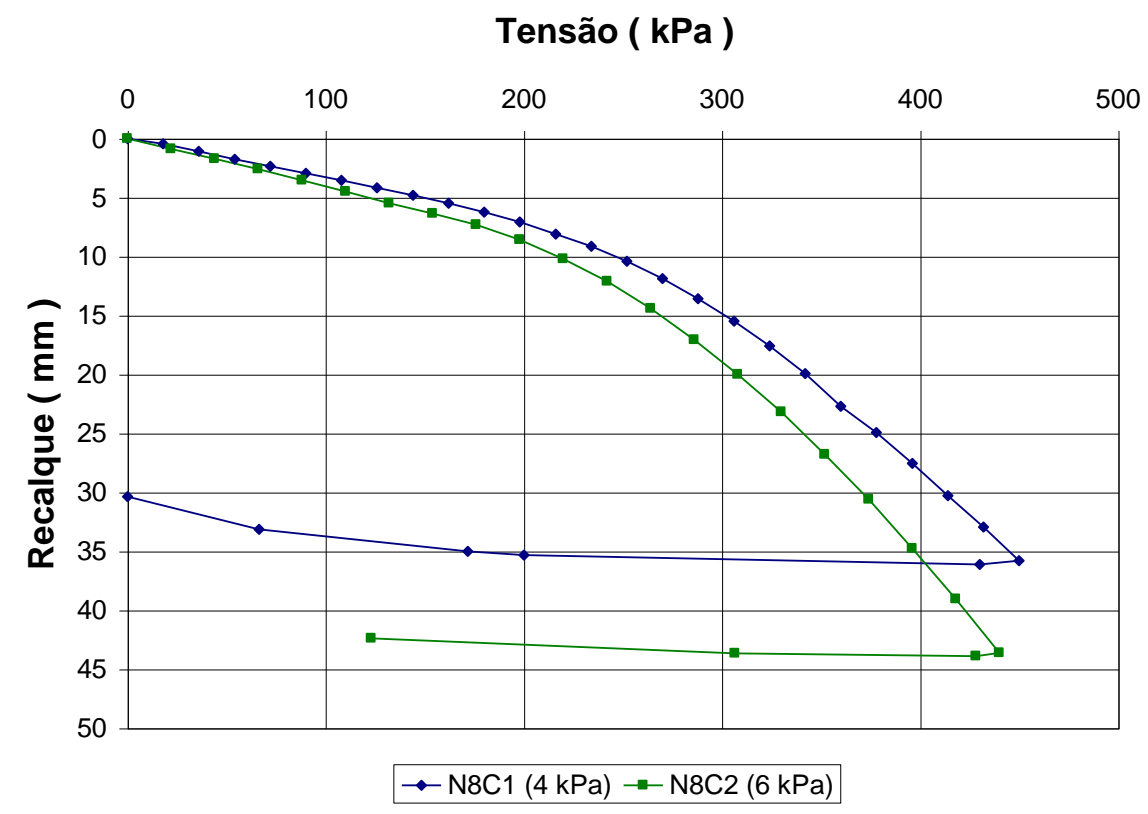

FIGURA 5.6: Curvas tensão $x$ recalque para profundidade de $8,0 \mathrm{~m}$.

$\mathrm{Na}$ figura 5.4 observou-se uma diferença significativa entre os resultados obtidos entre os ensaios saturados. Convém aqui salientar que quando da realização da prova de carga S4C3 observou-se "in loco" que o solo encontrado na cota de assentamento da placa apresentava pouca rigidez, fato esse não confirmado na realização da prova de carga $\mathrm{S} 4 \mathrm{C} 4$, portanto tal diferença pode ser explicada pela heterogeneidade do maciço de solo. 


\section{6 - ANÁLISE DOS DADOS}

Nesta análise foram incluídas quatro provas de carga realizadas por COSTA (1999) a 1,5 m de profundidade no campo experimental de fundações da USP/São Carlos, cujos dados estão resumidos na tabela 6.1.

TABELA 6.1: Características das provas de carga realizadas por COSTA (1999).

\begin{tabular}{l|c|c|c|c|c}
\hline $\begin{array}{c}\text { Prova de } \\
\text { carga }\end{array}$ & $\begin{array}{c}\text { Prof. } \\
(\mathbf{m})\end{array}$ & Data & Inundação & $\begin{array}{c}\text { Sucção média } \\
(\mathbf{k P a})\end{array}$ & $\begin{array}{c}\text { Teor de umidade } \\
\text { médio }(\%)\end{array}$ \\
\hline QS1 & 1,5 & $14 / 10 / 98$ & Sim & 0 & -- \\
QS2 & 1,5 & $05 / 06 / 98$ & Sim & 0 & -- \\
Q1 & 1,5 & $24 / 10 / 98$ & Não & 15 & 16,60 \\
Q2 & 1,5 & $05 / 07 / 99$ & Não & 22 & 15,75 \\
\hline
\end{tabular}

\section{1 - Relação entre a sucção matricial e o teor de umidade}

Para cada ensaio não inundado, inclusive os realizados por COSTA (1999), pode-se associar o valor médio da sução matricial, obtido através dos tensiômetros, com o valor médio do teor de umidade determinado nas amostras deformadas.

A variação da sucção com o teor de umidade está apresentada na figura 6.1, para cada profundidade de ensaio. 
Observa-se uma tendência de variação da sucção com o teor de umidade nas diferentes profundidades ensaiadas.

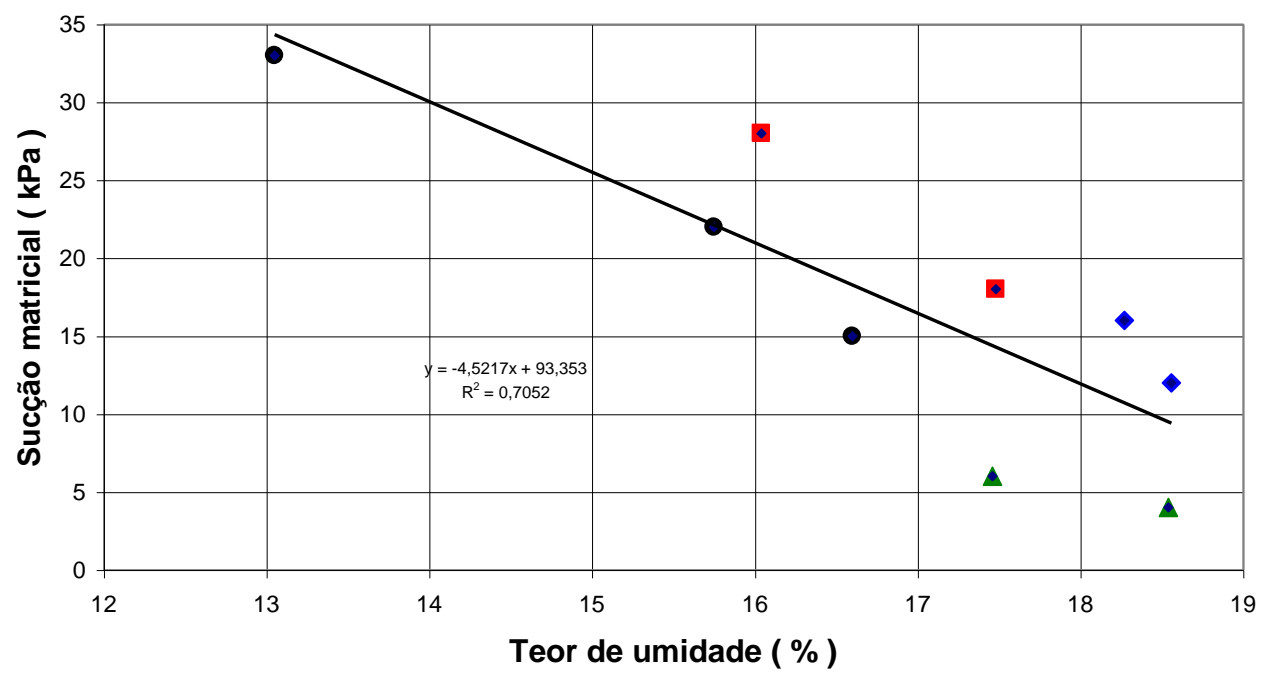

- prof. $1,5 \mathrm{~m} \backsim$ prof. $4,0 \mathrm{~m} \bullet$ prof. $6,0 \mathrm{~m} \Delta$ prof. 8,0 m — Linear (tendência)

FIGURA 6.1: Sucção matricial x teor de umidade, associados a profundidade do ensaio

\section{2 - Tensão de ruptura}

Observando-se a forma das curvas tensão $\mathrm{x}$ recalque obtidas nas provas de carga, verificou-se a existência de um trecho final praticamente linear, o que não caracteriza uma ruptura nítida do sistema nem permite aplicar o modelo de ruptura física. Por isso, foram adotados dois critérios de ruptura convencional.

De acordo com TEIXEIRA \& GODOY (1998) o código de obras da cidade de Boston - USA estipula que, para interpretar os resultados de uma prova de carga, deve-se atender sempre aos critérios de recalque e ruptura.
a) critério de recalque: $\bar{\sigma} \leq \sigma_{10}$
b) critério de ruptura: $\bar{\sigma} \leq \sigma_{25} / 2$ 
onde:

$\sigma_{10}$ é a tensão que corresponde a um recalque de $10 \mathrm{~mm}$.

$\sigma_{25}$ é a tensão que corresponde a um recalque de $25 \mathrm{~mm}$.

Analisando o critério de ruptura, se a tensão admissível é dada pela tensão que corresponde a um recalque de $25 \mathrm{~mm}$, dividida por um coeficiente de segurança igual a 2 , subentende-se que esse valor de tensão refere-se a de ruptura.

Por isso, adotou-se como um critério de ruptura convencional aquele em que o valor da tensão de ruptura corresponde ao recalque de $25 \mathrm{~mm}$. É interessante observar que, esse valor de recalque praticamente coincide com a parcela D/30 do critério de ruptura convencional da NBR 6122/96, para provas de carga em estacas, se aplicado a uma placa de $80 \mathrm{~cm}$ de diâmetro (COSTA, 1999).

Aplicando esse critério obtêm-se os valores de tensão de ruptura convencional $\left(\sigma \mathrm{r}_{25}\right)$ apresentados no anexo C. Com esses dados foi possível construir as figuras 6.2 e 6.3 que indicam a variação de $\sigma \mathrm{r}_{25} \mathrm{com}$ a profundidade de assentamento da placa, para os ensaios não inundados e inundados. 


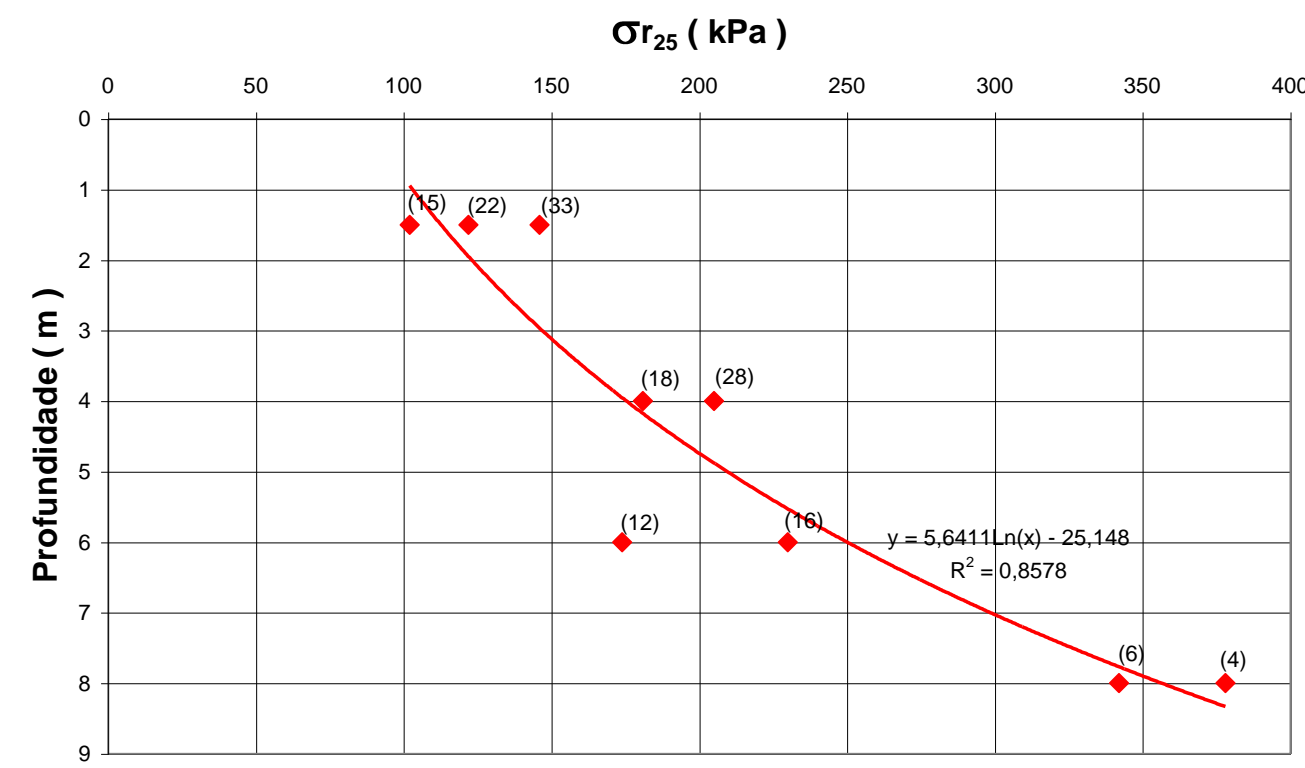

FIGURA 6.2: Profundidade $x$ tensão para o recalque de $25 \mathrm{~mm}$ (o valor entre parênteses indica a sucção em $\mathrm{kPa}$ )

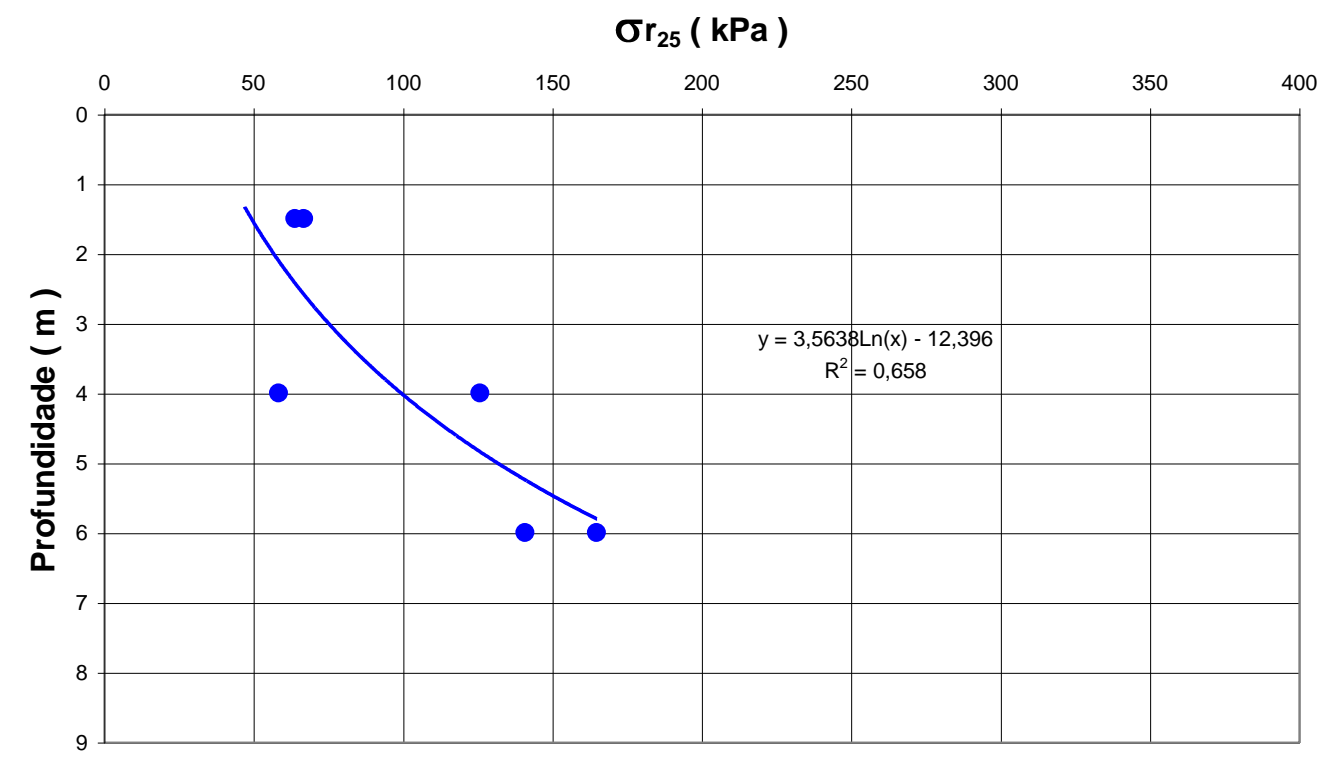

FIGURA 6.3: Profundidade $x$ tensão para o recalque de $25 \mathrm{~mm}$ (ensaios inundados) 
Outro critério de ruptura convencional pode ser considerado devido à semelhança da forma da curva tensão x recalque obtida nas provas de carga com a da curva e $\mathrm{x} \log \sigma$ de um ensaio de adensamento.

Por isso, aplicou-se o método de Pacheco Silva (1970), em todas as provas de carga, para determinar uma espécie de tensão de pré-adensamento. Um exemplo deste procedimento é apresentado na figura 6.4, para o ensaio N1C3.

\section{Tensão ( kPa )}

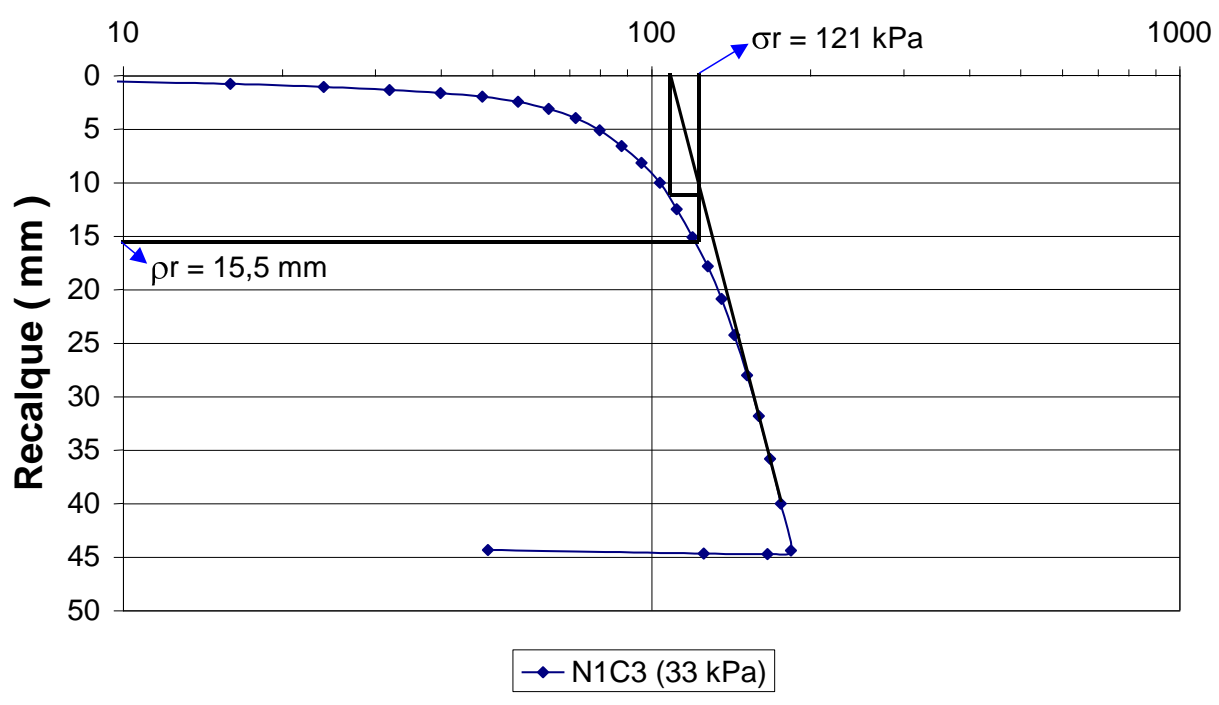

FIGURA 6.4: Curva tensão $x$ recalque (escala mono-logarítmica).

Aplicando-se esse critério, obtêm-se os valores de tensão de ruptura convencional ( $\sigma r)$ e os correspondentes recalques ( $\rho r)$ apresentados no anexo C.

As figuras 6.5 e 6.6 mostram a variação de or com a profundidade, para os ensaios não inundados e inundados. 


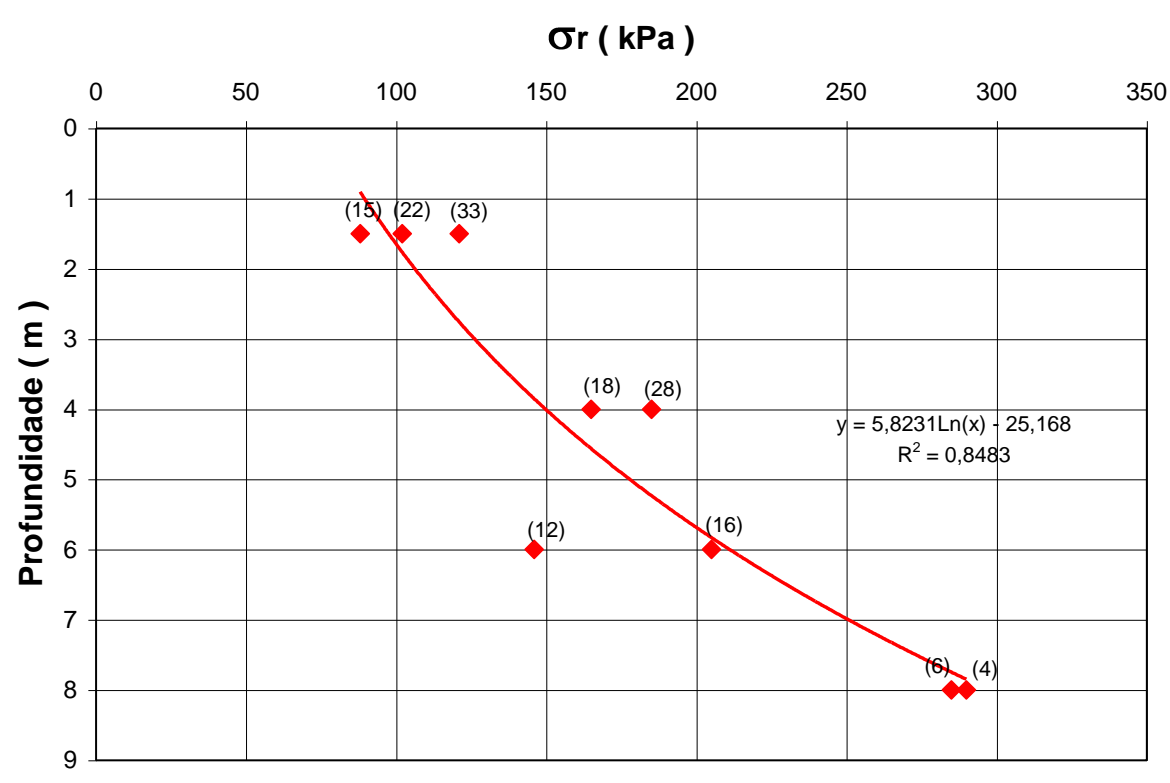

FIGURA 6.5: Profundidade $\mathrm{x}$ or

( o valor entre parênteses indica a sucção em $\mathrm{kPa}$ )

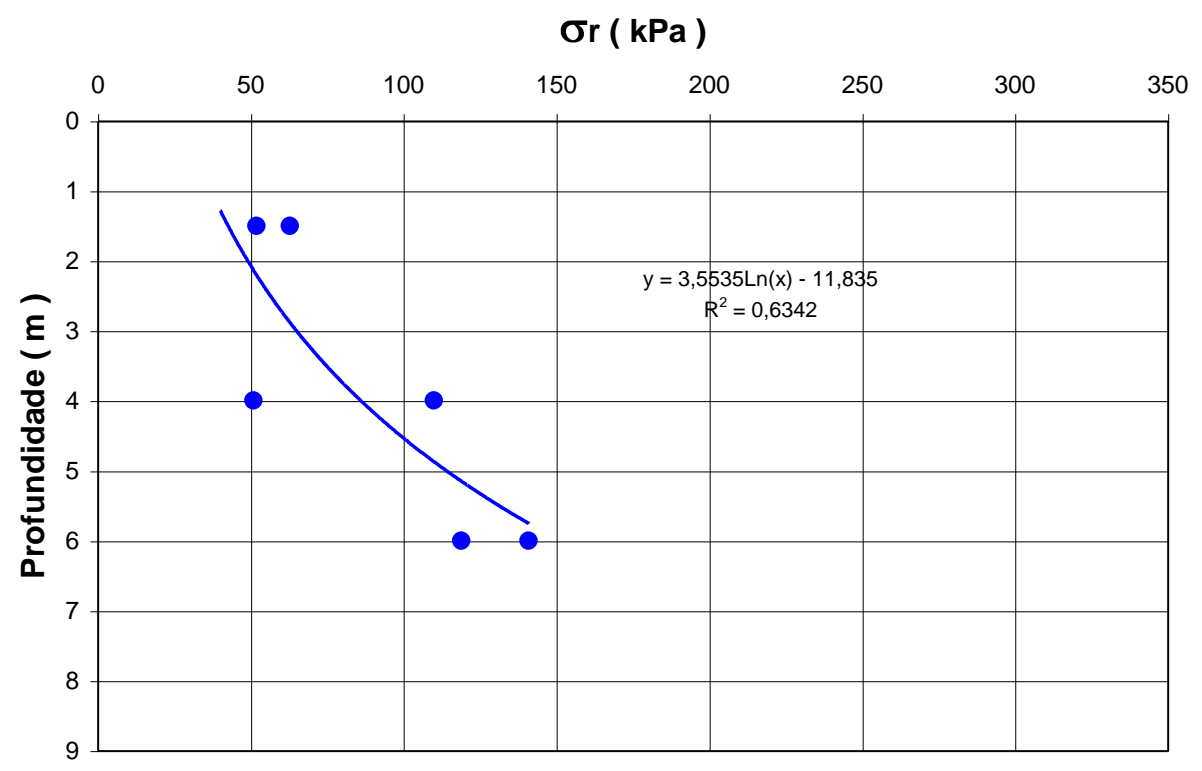

FIGURA 6.6: Profundidade $x$ or

(ensaios inundados) 
Observa-se que independente do critério de ruptura adotado, a tensão de ruptura cresceu com o aumento da profundidade.

Também se verifica que para a mesma profundidade de ensaio, a prova de carga com maior sucção matricial média apresenta maior tensão de ruptura para ambos os critérios de ruptura, exceto para as provas de carga realizadas a 8,0 m de profundidade, devido à pequena diferença entre as medidas de sucção (4 e $6 \mathrm{kPa})$.

A variação do recalque ( $\rho r)$ correspondente à tensão de ruptura convencional $(\sigma r)$, com a profundidade, pode ser observada nas figuras 6.7 e 6.8 .

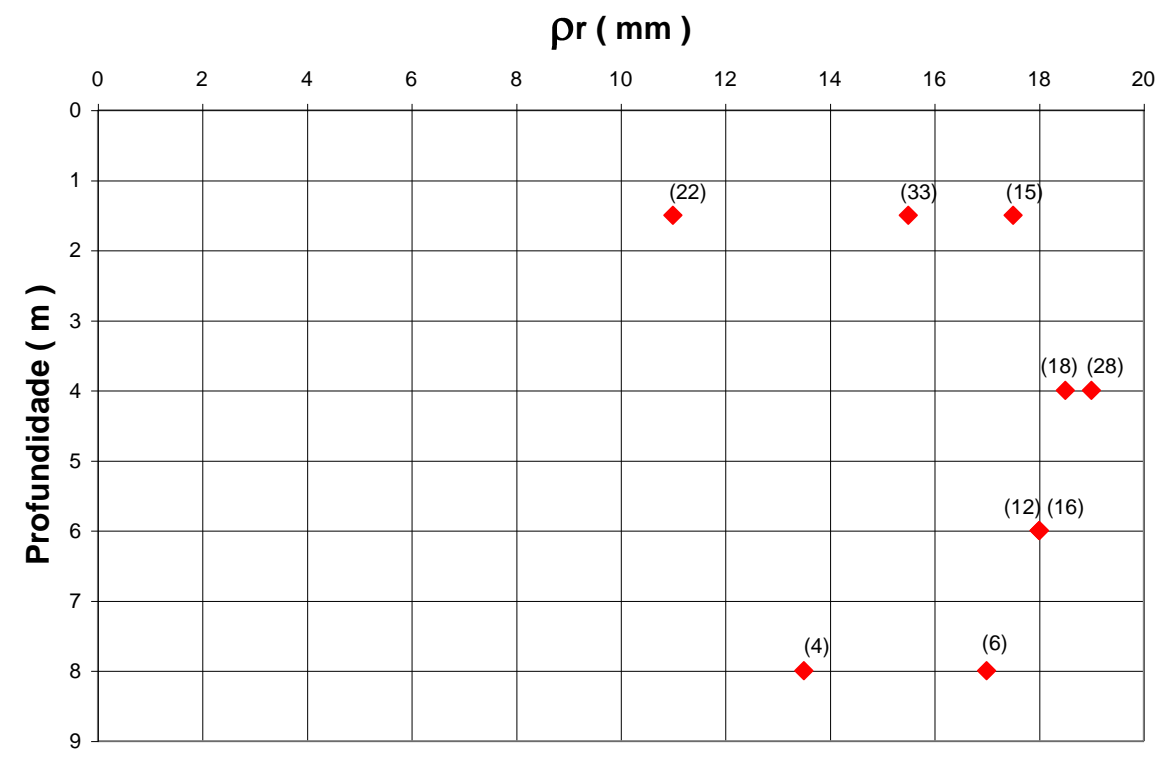

FIGURA 6.7: Profundidade $\mathrm{x} \rho \mathrm{r}-$ ensaios não inundados.

(o valor entre parênteses indica a sucção) 


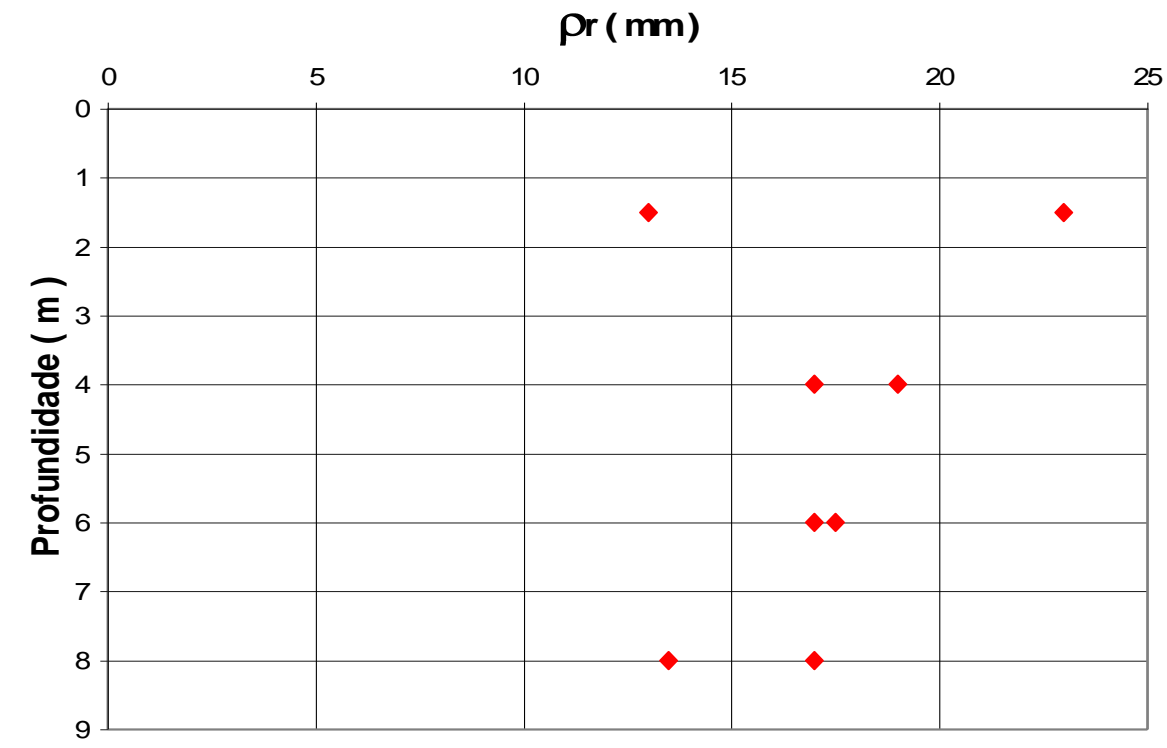

FIGURA 6.8: Profundidade x pr - ensaios inundados.

Observando-se as figuras 6.7 e 6.8 verifica-se que o recalque correspondente à tensão de ruptura convencional não apresenta uma lei de variação com a profundidade.

\section{3 - Influência da sucção e da profundidade}

Nas figuras 5.3 a 5.6, pode-se observar o comportamento do sistema com a variação da sucção matricial. Para a mesma profundidade de ensaio, é necessário aplicar uma tensão maior, quanto maior for a sucção, para gerar o mesmo recalque.

Nas figuras 6.9 e 6.10, apresenta-se a variação da tensão de ruptura convencional com a sucção, para os dois critérios de ruptura adotados, levando-se em consideração a profundidade em que cada prova de carga foi realizada.

Nessas figuras também são comparados os resultados obtidos por regressão linear múltipla. Essas regressões correlacionam a tensão de ruptura com a sucção e profundidade (até 6,0 m). 


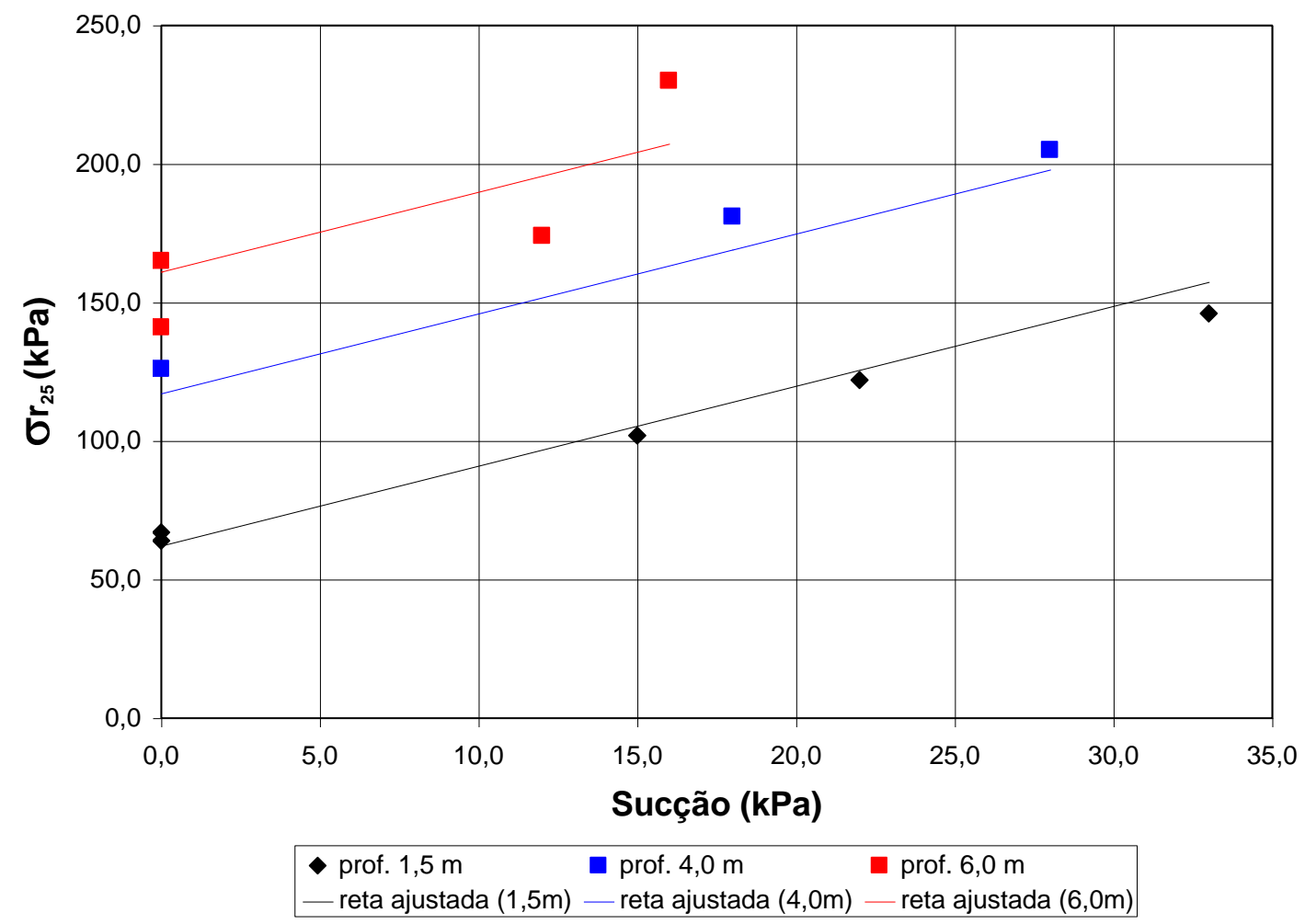

FIGURA 6.9 - Tensão de ruptura para recalque de $25 \mathrm{~mm}$ x sucção x profundidade.

Para o critério de ruptura associado ao recalque de $25 \mathrm{~mm}$, obtêm-se a seguinte correlação:

$$
\begin{array}{r}
\sigma \mathbf{r}_{25}=2,88 * \text { sucção }+21,97 * \text { profundidade }+29,34 \\
\qquad \mathrm{R}^{2}=0,9403
\end{array}
$$

Onde:

tensão e sucção em kPa, e profundidade em m. 


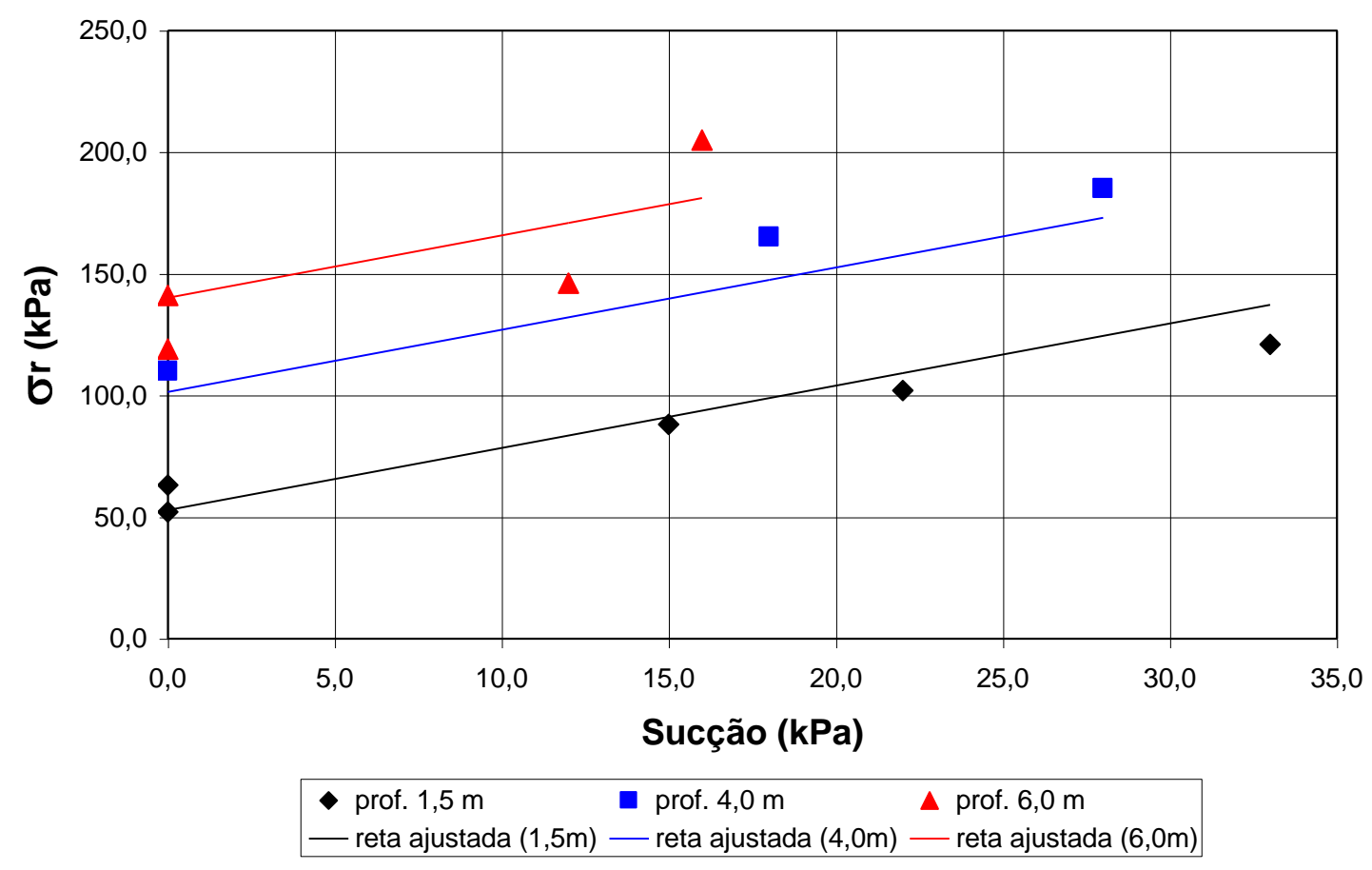

FIGURA 6.10 - Tensão de ruptura de Pacheco Silva (1970) x sucção x profundidade.

De forma semelhante, utilizando o método Pacheco Silva (1970), para obter a tensão de ruptura convencional, encontra-se a seguinte correlação:

$$
\sigma \mathrm{r}=2,56 * \text { sucção }+19,41 * \text { profundidade }+23,66
$$

$$
\mathrm{R}^{2}=0,9024
$$

Onde:

tensão e sucção em kPa, e profundidade em $\mathrm{m}$. 


\section{4 - Comparação com ensaios de compressão confinada}

Neste item são realizadas comparações entre os resultados obtidos nas provas de carga e os resultados de ensaios de compressão confinada, com respeito à tensão de pré-adensamento e à tensão de ruptura. Os ensaios de laboratório foram realizados em corpos de prova de amostras coletadas no Campo Experimental de Fundações da USP/São Carlos, às profundidades de 1,0 , 2,0 , 3,0 , 4,0 , 5,0 , 7,0 e 8,5 m (MACHADO, 1998).

Os ensaios edométricos foram realizados segundo duas trajetórias. $\mathrm{Na}$ primeira, a sucção do corpo de prova era mantida constante, enquanto o mesmo sofria compressão. Na segunda, o corpo de prova era inundado, passando a ter sucção próxima de zero e, em seguida, eram aplicados os carregamentos. Dessa forma os ensaios edométricos se assemelhariam às condições do solo (inundados ou não) em que as provas de carga foram realizadas.

As figuras 6.11 a 6.14 exibem curvas de variação da tensão de préadensamento ( $\sigma \mathrm{ad})$ em função da sucção, obtidas por MACHADO (1998), juntamente com os valores de tensão de ruptura obtidos nas provas de carga.

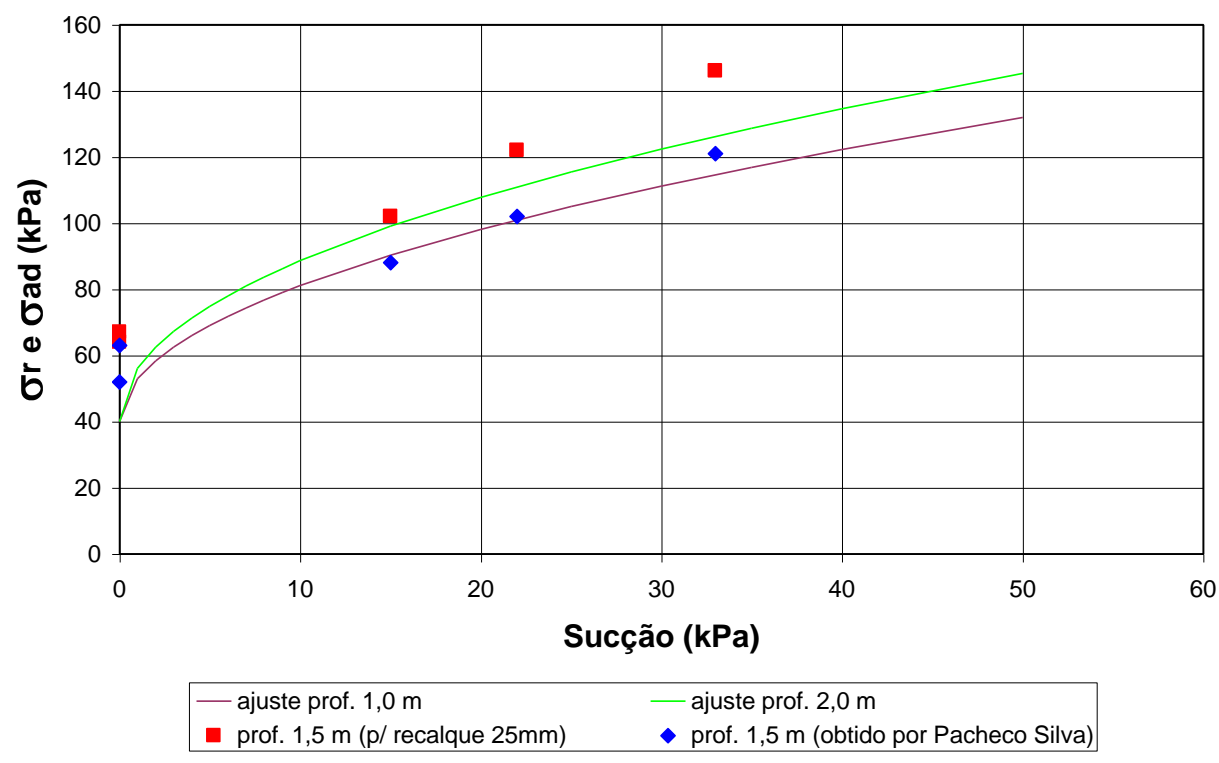

FIGURA 6.11 -Variação da tensão de pré-adensamento e da tensão de ruptura com a sucção. 


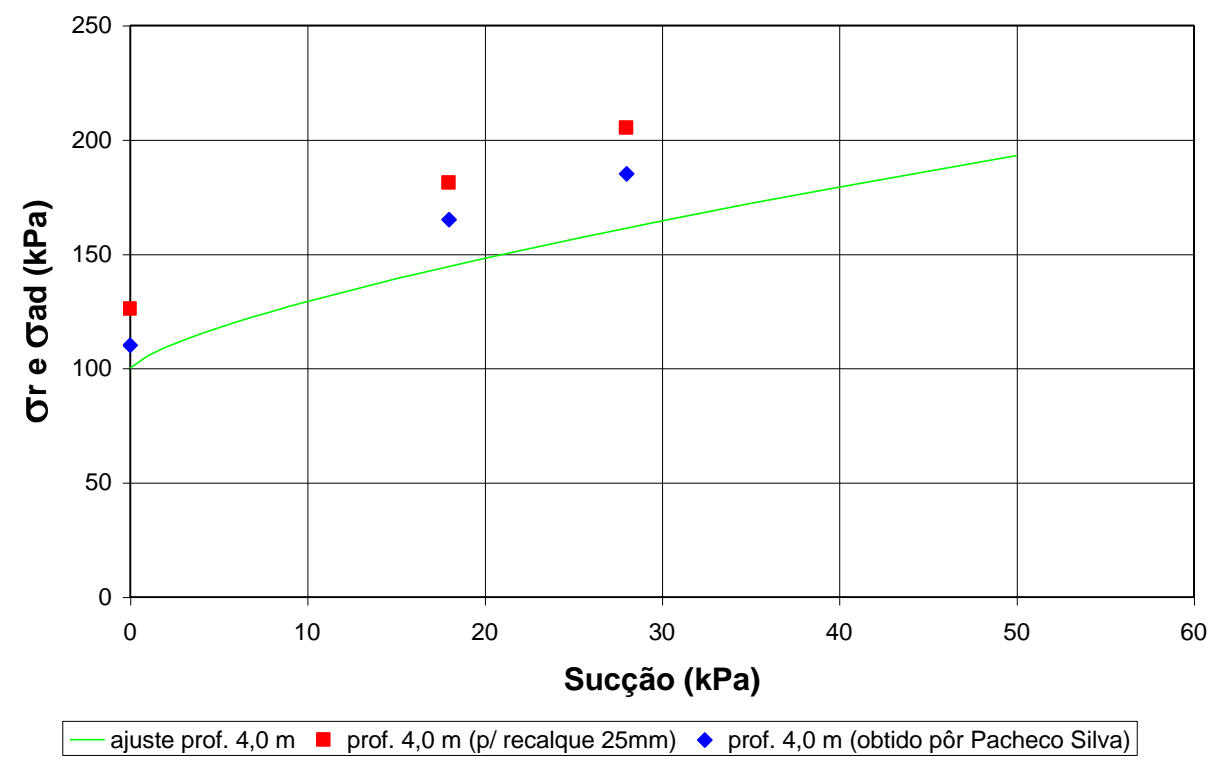

FIGURA 6.12 - Variação da tensão de pré-adensamento e da tensão de ruptura com a sucção.

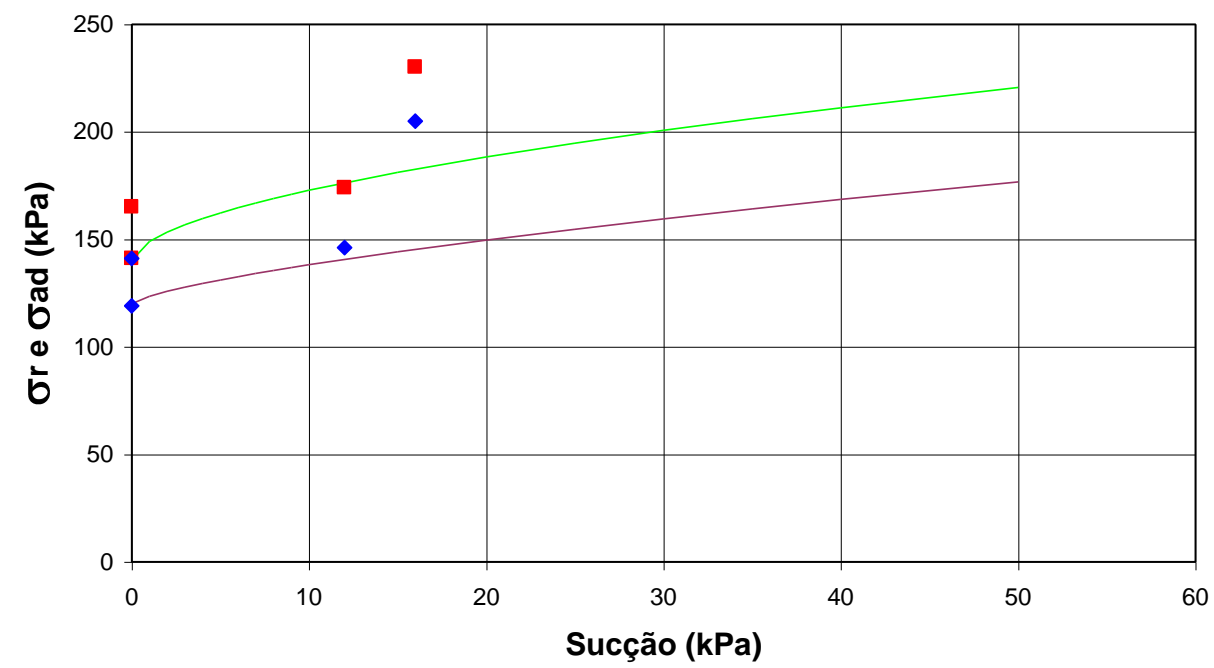

- ajuste prof. $5,0 \mathrm{~m}$
prof. $6,0 \mathrm{~m}(\mathrm{p} /$ recalque $25 \mathrm{~mm}) \quad$ ajuste prof. $7,0 \mathrm{~m}$

FIGURA 6.13 - Variação da tensão de pré-adensamento e da tensão de ruptura com a sucção. 


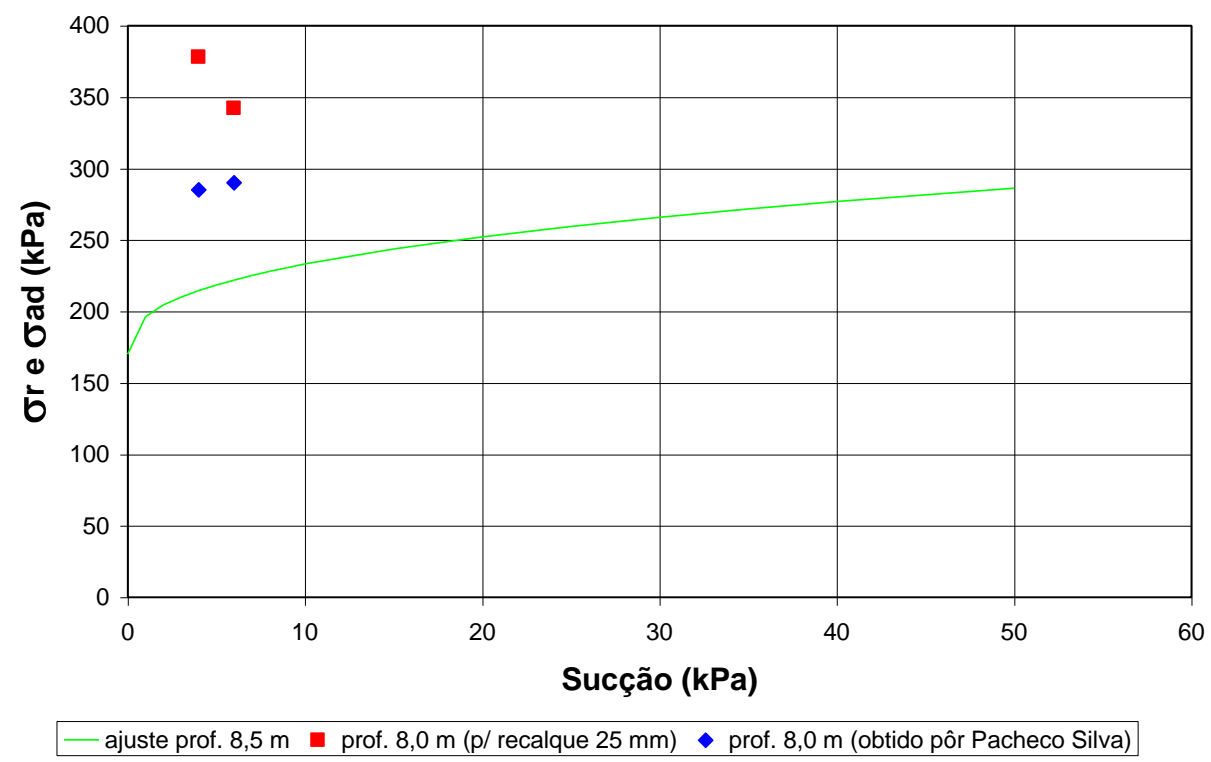

FIGURA 6.14 - Variação da tensão de pré-adensamento e da tensão de ruptura com a sucção.

As figuras 6.11 a 6.14 revelam que as tensões de ruptura relacionamse com a sucção de forma relativamente adequada (a favor da segurança) aos ajustes efetuados por MACHADO (1998) para a variação da tensão de pré-adensamento com a sucção nos ensaios edométricos, porém para a profundidade de $8,0 \mathrm{~m}$ os valores de tensão de ruptura se mostraram distantes do ajuste proposto por MACHADO (1998).

\section{5 - Redução da tensão de ruptura devido à inundação}

Para a mesma profundidade de ensaio, a comparação da tensão de ruptura do ensaio não inundado com o ensaio inundado caracteriza uma redução da tensão de ruptura devido ao colapso do solo. Evidentemente essa redução é mais expressiva quanto maior for a sucção no ensaio não inundado (tabelas 6.2 e 6.3). 
TABELA 6.2 - Redução da tensão de ruptura para recalque de $25 \mathrm{~mm}$ em relação à tensão de colapso para as profundidades de 1,5, 4,0 e 6,0 m.

\begin{tabular}{c|c|c|c}
\hline Ensaio & Prof. (m) & Sucção $(\mathrm{kPa})$ & Redução de $\sigma_{25}(\%)$ \\
\hline Q1 & 1,5 & 15 & 36 \\
Q2 & 1,5 & 22 & 46 \\
N1C3 & 1,5 & 33 & 55 \\
N4C1 & 4,0 & 18 & 30 \\
N4C2 & 4,0 & 28 & 38 \\
N6C1 & 6,0 & 12 & 12 \\
N6C2 & 6,0 & 16 & 33 \\
\hline
\end{tabular}

TABELA 6.3 - Redução da tensão de ruptura de Pacheco Silva (1970) em relação à tensão de colapso para as profundidades de 1,5 , 4,0 e 6,0 m.

\begin{tabular}{c|c|c|c}
\hline Ensaio & Prof. (m) & Sucção $(\mathrm{kPa})$ & Redução de $\sigma \mathrm{r}(\%)$ \\
\hline Q1 & 1,5 & 15 & 35 \\
Q2 & 1,5 & 22 & 44 \\
N1C3 & 1,5 & 33 & 52 \\
N4C1 & 4,0 & 18 & 33 \\
N4C2 & 4,0 & 28 & 41 \\
N6C1 & 6,0 & 12 & 11 \\
N6C2 & 6,0 & 16 & 37 \\
\hline
\end{tabular}




\section{6 - Curva característica de sucção do solo}

As figuras 6.15 a 6.17 exibem curvas de variação da umidade volumétrica em função da sucção matricial, para as profundidades de 2,0 , 5,0 e 8,0 m, obtidas por MACHADO (1998), juntamente com os valores obtidos no campo. Estão indicados também nestas figuras os trechos em que se utilizou o método do funil de placa porosa e a câmara de Richards, para obtenção da curva característica de sucção do solo.

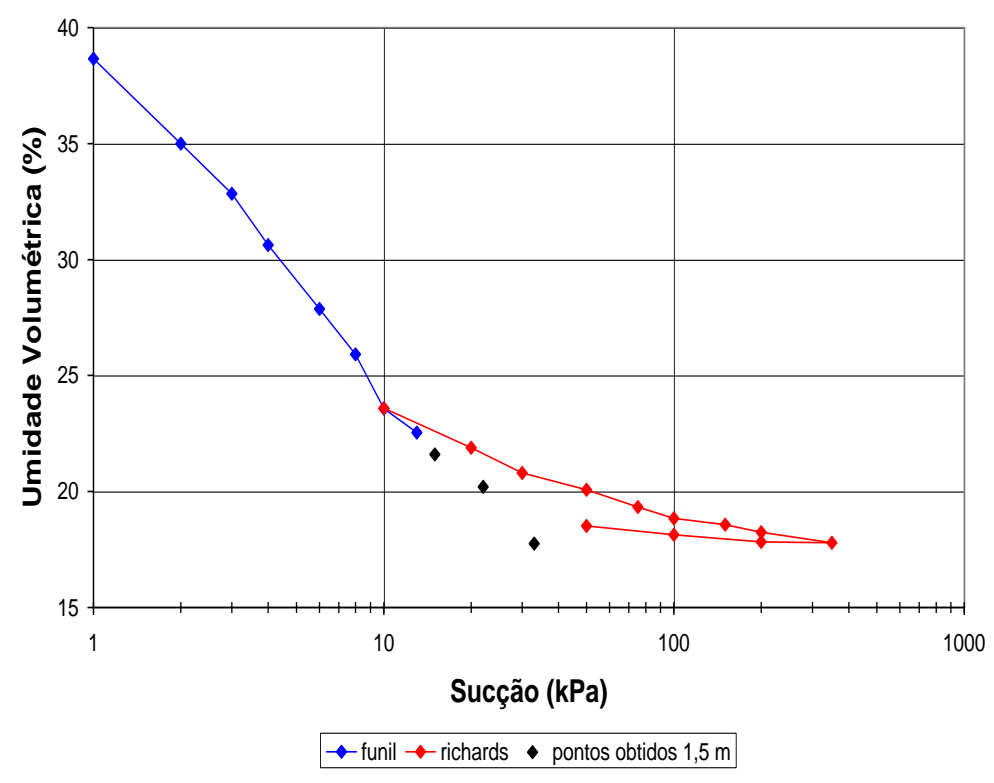

FIGURA 6.15 - Comparação entre os valores de umidade volumétrica obtidos com a curva característica de sucção do solo para a profundidade de $2,0 \mathrm{~m}$. 


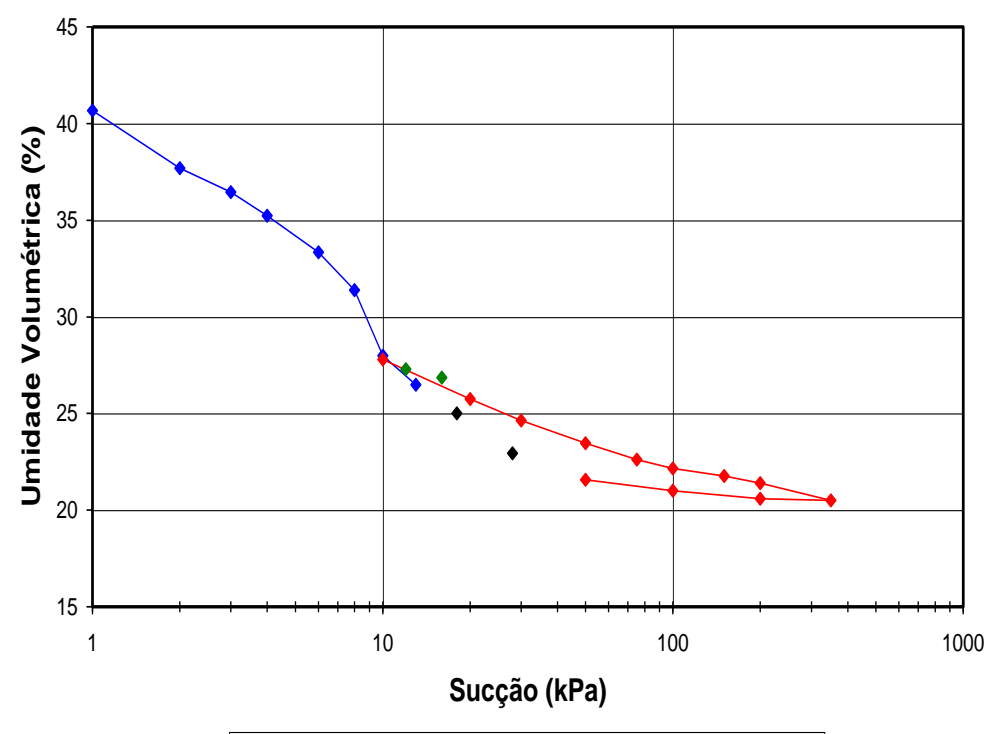

$\rightarrow$ funil $\rightarrow$ - richards $\bullet$ pontos obtidos $4 \mathrm{~m} \bullet$ pontos obtidos $6 \mathrm{~m}$

FIGURA 6.16 - Comparação entre os valores de umidade volumétrica obtidos com a curva característica de sucção do solo para a profundidade de $5,0 \mathrm{~m}$.

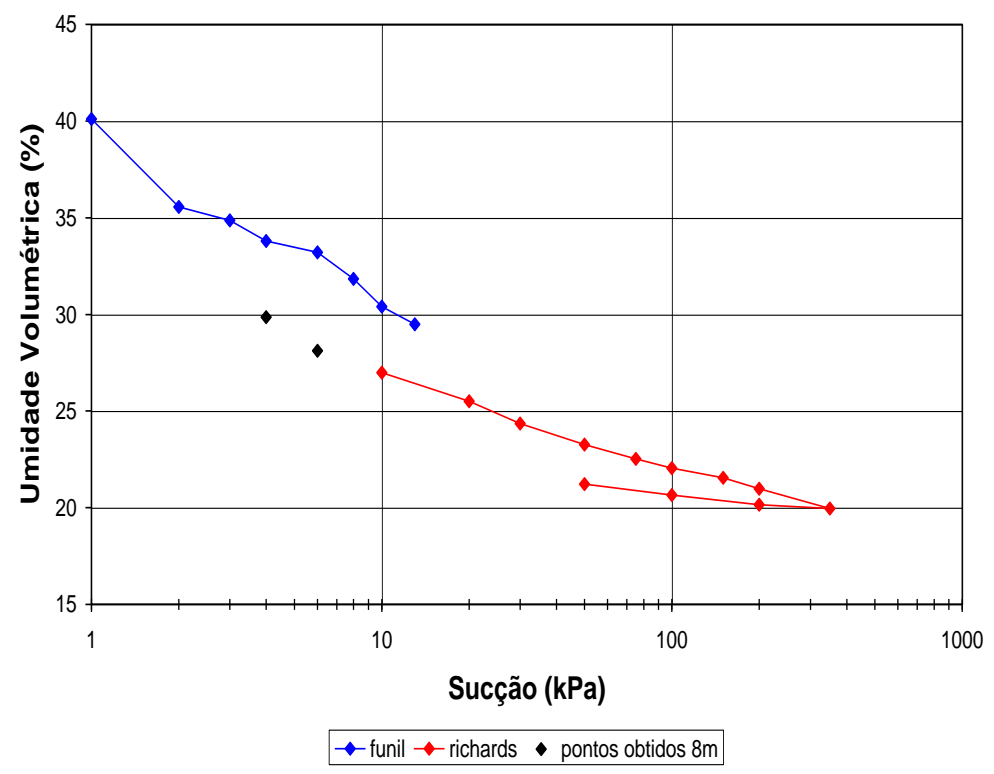

FIGURA 6.17 - Comparação entre os valores de umidade volumétrica obtidos com a curva característica de sucção do solo para a profundidade de $8,0 \mathrm{~m}$. 
As figuras 6.15 a 6.17 revelam que os valores obtidos no campo relacionam-se com as curvas características de sucção do solo obtidas por MACHADO (1998) de forma relativamente adequada. 


\section{7 - CONCLUSÕES E SUGESTÕES PARA PESQUISAS FUTURAS}

\section{1 - Conclusões}

Do exposto neste trabalho, conclui-se que:

a) A sucção possui grande influência na capacidade de carga, para a mesma profundidade de ensaio.

b) Com o aumento da profundidade ocorre um acréscimo da capacidade de carga, para um mesmo nível de sucção. Ao ultrapassar a camada de sedimento do cenozóico e alcançar solo residual do Grupo Bauru, o acréscimo de capacidade de carga é mais acentuado.

c) Foi possível desenvolver uma correlação entre a tensão de ruptura, a sucção e a profundidade (até $6 \mathrm{~m}$ ).

d) O método de PACHECO SILVA (1970) pode ser utilizado como critério de ruptura convencional na interpretação de ensaios de placa neste tipo de solo.

e) A tensão de ruptura relaciona-se com a sucção de forma satisfatória (a favor da segurança) aos ajustes propostos por MACHADO (1998) para a variação da tensão de pré-adensamento 
com a sucção nos ensaios edométricos, exceto para a profundidade de $8,0 \mathrm{~m}$ (solo residual) os valores de tensão de ruptura mostraram-se distantes do ajuste proposto.

f) Para os níveis de sucção média encontrada nos ensaios realizados, a redução da tensão de ruptura devido ao colapso foi da ordem de 30 a 50\%, para ambos os critérios de ruptura convencional.

g) Os valores de umidade volumétrica em função da sucção, obtidos no campo, relacionaram-se de forma relativamente adequada à curva característica de sucção do solo obtida por MACHADO (1998)

\section{2 - Sugestões para pesquisas futuras}

a) Realizar um maior número de ensaios para melhor definir a variação da tensão de ruptura com a profundidade do ensaio.

b) Realizar um maior número de provas de carga na camada de solo residual (quando o nível d'água permitir), com o objetivo de melhor conhecer o comportamento desse maciço de solo.

c) Coletar maior número de dados relativos ao teor de umidade e sucção ao longo do perfil do maciço de solo, para se criar uma espécie de curva característica de sucção do solo com dados de campo.

d) Realizar um número maior de ensaios edométricos com valores de sucção próximo aos valores comumente encontrados em campo para melhor comparar a tensão de pré-adensamento com a tensão de ruptura obtida no campo. 


\section{8 - BIBLIOGRAFIA}

ABNT - MB 3472 (1991) - "Estacas - Provas de Carga Estática". Rio de Janeiro.

ABNT - NBR 6489 (1984) - "Prova de carga direta sobre terreno de fundação". Rio de Janeiro.

ABNT - NBR 6122 (1996) - "Projeto e execução de fundações". Rio de Janeiro

AGNELLI, N. (1992) - Estudo da colapsividade do solo de Bauru através de provas de carga diretas. Dissertação de Mestrado, EESC/USP, São Carlos/SP, 172 p.

AGNELLI, N. (1994) - Efeito da colapsividade no resultado de provas de carga direta. X Congresso Brasileiro de Mecânica dos Solos e Engenharia de Fundações / $1^{\circ}$ Simpósio Brasileiro de Mecânica das Rochas, Vol. I, pag. 167.

AOKI, N. (2000) - O futuro da engenharia de fundações. Palestra no Clube de Engenharia, Rio de Janeiro/RJ, Novembro.

ALONSO, U.R. (1997) - Prova de carga estática em estacas (uma proposta para revisão da norma da NBR 12131). Solos e Rochas, v. 20, n. 1, p. 47-50, abr. 
BARATA, F.E. (1984) - Uma introdução ao projeto de fundações. Rio de Janeiro, Livros Técnicos e Científicos.

BORTOLUCCI, A.A. (1983) - Caracterização geológico-geotécnica da região urbana de São Carlos - SP, a partir de sondagens de simples reconhecimento. Dissertação de Mestrado, EESC/USP, São Carlos/SP.

CINTRA， J.C.A.; CARVALHO, D.; GIACHETI, H.L.; BORTOLUCCI, A.A. \& ALBIERO, J.H. (1991) - Campo Experimental de Fundações de São Carlos. SEFE II, São Paulo, V. 1, p. 105.

CINTRA, J.C.A. (1998) - Fundações em Solos Colapsíveis. Projeto Reenge, EESC/USP, São Carlos/SP, 116 p.

COSTA, Y.D.J. (1999) - Estudo do comportamento de solo não saturado através de provas de carga em placa. Dissertação de Mestrado, EESC/USP, São Carlos/SP, 131 p.

CONSOLI, N.; SCHNAID, F.; MILITITSKY， J. (1998) Interpretation of plate load tests on residual soil site. Journal of Geotechnical and Geoenvironmental Engineering, v. 124, n. 9, p. 857867.

De MELLO, V.F.B. (1975) - Deformações como base fundamental de escolha da fundação. Geotecnia, ${ }^{\circ} 12$, p. 55-75.

DÉCOURT, L.; QUARESMA, A.R.F ${ }^{\circ}$ (1996) - Estabelecimento das curvas carga x recalque de fundações através de provas de carga em mini-placa. SEFE III, São Paulo, V. 2, p. 225-235. 
FELLENIUS, B.H. (1975) - Test load of piles and new proof test procedure. ASCE, Journal of Geotechnical Engineering Division, $\mathrm{n}^{\circ}$ 101, GT9: p. 855-869.

FREDLUND, D.G.; RAHARDJO, H. (1993) - Soil Mechanics for Unsaturated Soils. New York, John Wiley \& Sons.

IPT (1954) - Estudo das fundações para as futuras instalações da Escola de Engenharia de São Carlos. Relatório n 2269, São Paulo.

MACHADO, S.L. (1998) - Aplicações de conceitos de elastoplasticidade a solos não saturados. Tese de Doutorado, EESC/USP, São Carlos/SP, 362 p.

MASSAD, E. (1985) - Provas de carga e acompanhamento de recalques. SEFE, São Paulo, V. 2, p. 9-72.

NÁPOLES NETO (1954) - Estudo dos recalques de um grande castelo d'água fundado em solo residual. $1^{\circ}$ Congresso Brasileiro de Mecânica dos solos e engenharia de fundações, Porto Alegre/RS.

PACHECO SILVA, F. (1970) - Uma nova construção gráfica para a determinação da pressão de pré-adensamento de uma amostra de solos. Congresso Brasileiro de Mecânica dos Solos e Engenharia de Fundações, Rio de Janeiro/RJ, Vol. II, Tomo I, p. 219-224.

SANTOS, T.R. (2001) - Atrito lateral e resistência de base em tubulões a céu aberto em solos colapsíveis. Dissertação de Mestrado, EESC/USP, São Carlos/SP, 171 p.

SOUTO SILVEIRA, E.B.S. \& SILVEIRA, A. (1958) - Investigação do arenito decomposto de São Carlos, para fundações de pequenas 
construções. Congresso Brasileiro de Mecânica dos Solos e Engenharia de Fundações, 2. Recife/Campina Grande, Anais, São Paulo, ABMS, V. 1, p. 77-110.

TEIXERA, A.H.; GODOY, N.S. (1998) - Fundações: Teoria e Prática. Ed. Pini Ltda, $2^{\circ}$ ed., p. 227-264.

VARGAS, M. (1978) - Introdução à Mecânica dos Solos. Editora McGraw-Hill do Brasil, 509 p.

VILAR, O.M.; RODRIGUES, J.E. \& NOGUEIRA, J.B. (1981) Solos Colapsíveis: um problema para a engenharia de solos tropicais. Simpósio Brasileiro de Solos Tropicais em Engenharia, Rio de Janeiro/RJ, V. 1, p. 209-224. 
ANEXO A - Calibração da célula de carga de 200 kN.

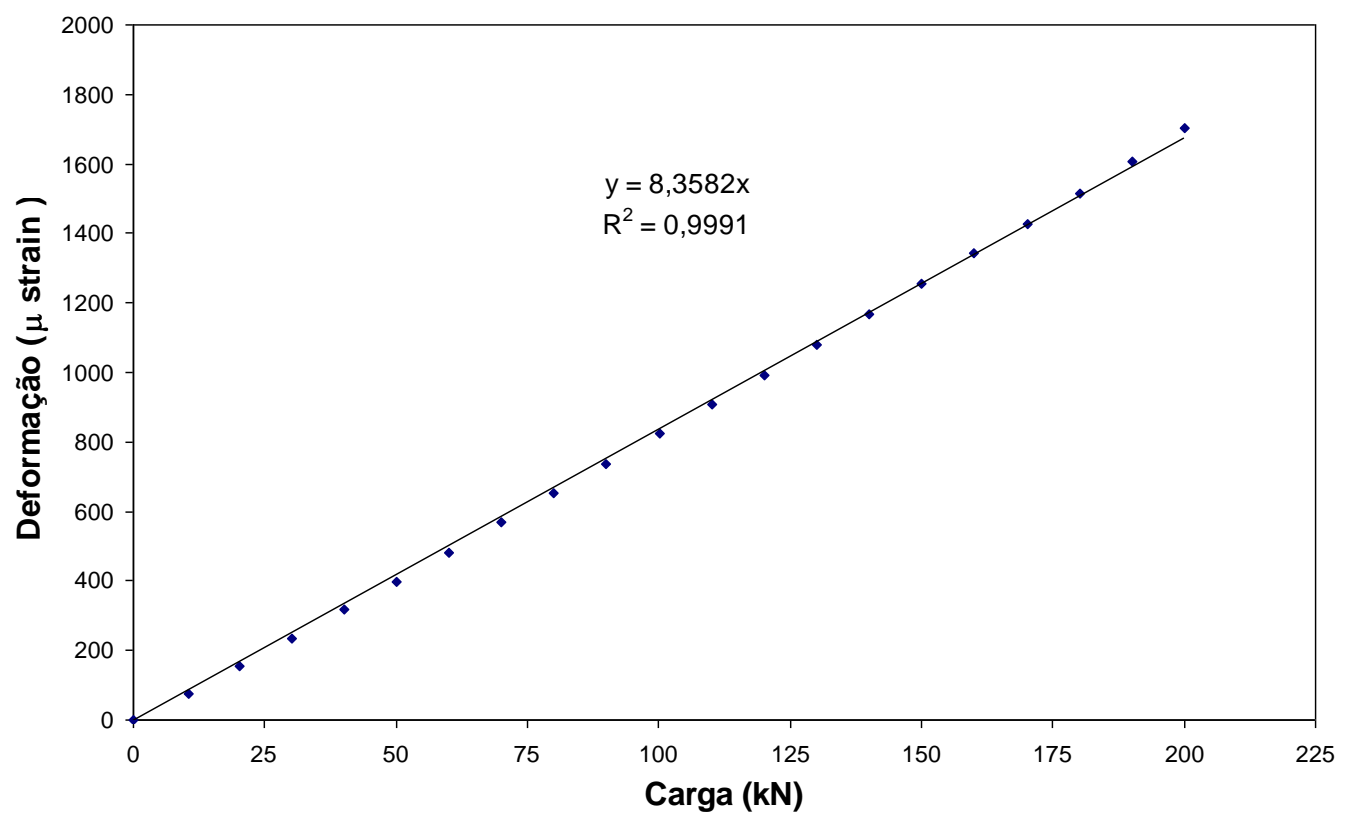


ANEXO B - Calibração da célula de carga de 500 kN.

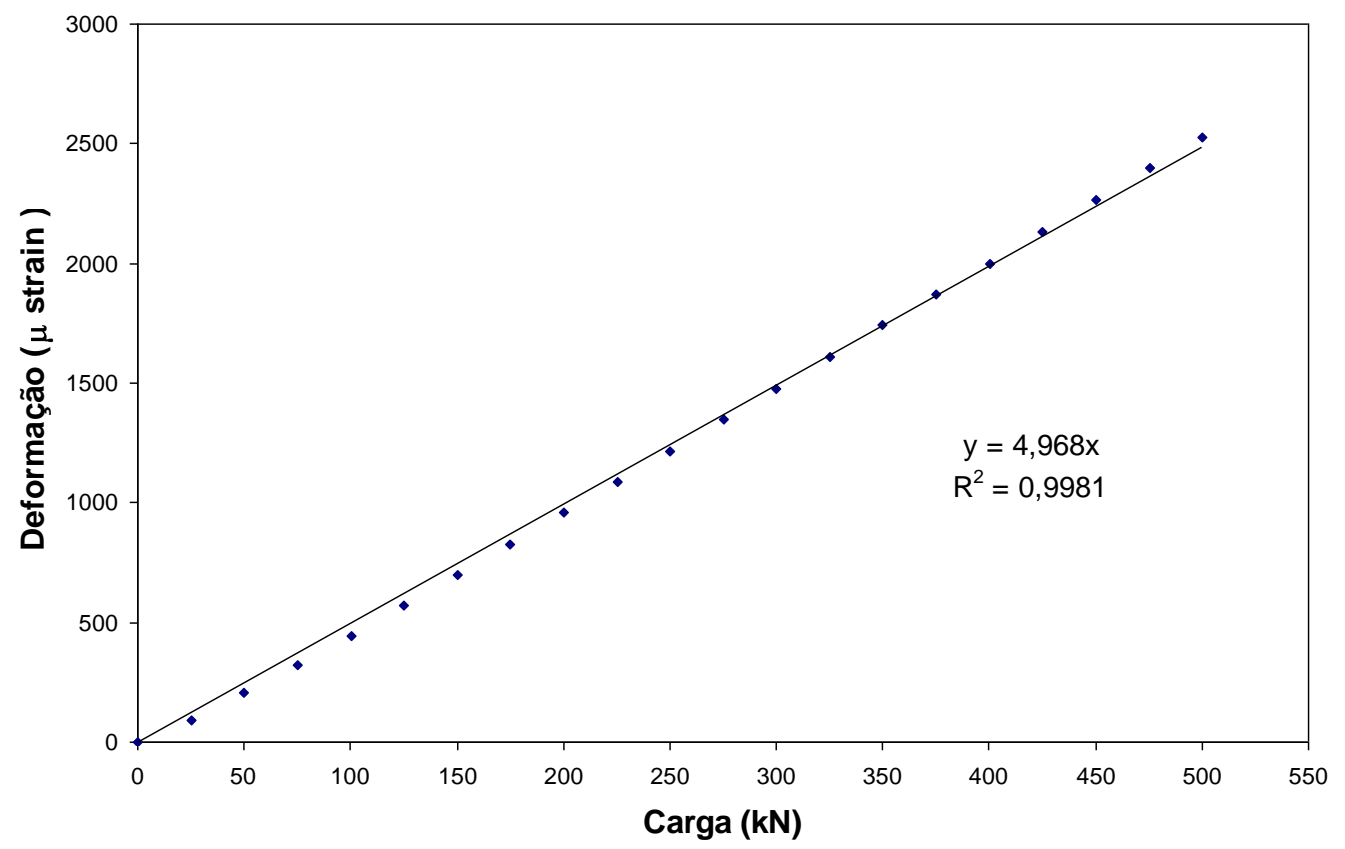


ANEXO C - Tensão de ruptura obtida utilizando o critério de 25 mm e o de Pacheco Silva (1970) com o correspondente recalque.

\begin{tabular}{|l|c|c|c|}
\hline \multicolumn{1}{|c|}{ Ensaio } & $\sigma_{25}(\mathrm{kPa})$ & $\sigma_{\mathrm{r}}(\mathrm{kPa})$ & $\rho_{\mathrm{r}}(\mathrm{mm})$ \\
\hline N1C3 & 146 & 121 & 15,5 \\
\hline N4C1 & 181 & 165 & 18,5 \\
\hline N4C2 & 205 & 185 & 19 \\
\hline S4C3 & 58,5 & 51 & 17 \\
\hline S4C4 & 126 & 110 & 19 \\
\hline N6C1 & 174 & 146 & 18 \\
\hline N6C2 & 230 & 205 & 18 \\
\hline S6C3 & 141 & 119 & 17 \\
\hline S6C4 & 165 & 141 & 17,5 \\
\hline N8C1 & 378 & 285 & 13,5 \\
\hline N8C2 & 342 & 290 & 17 \\
\hline Q1 & 102 & 88 & 17,5 \\
\hline Q2 & 122 & 102 & 11 \\
\hline QS1 & 64 & 52 & 23 \\
\hline QS2 & 67 & 63 & \\
\hline
\end{tabular}


ANEXO D - Planilhas das provas de carga.

$\begin{array}{crr}\text { ENSAIO - N1C3 } & & \\ \text { Tensão ( kPa ) } & \text { Leitura média do extensômetros } & \text { Recalque } \mathbf{( ~} \mathbf{~ m} \text { ) } \\ & & \\ 0 & 0,00 & 0,00 \\ 8 & 51,50 & 0,52 \\ 16 & 83,00 & 0,83 \\ 24 & 109,25 & 1,09 \\ 32 & 137,50 & 1,38 \\ 40 & 165,75 & 1,66 \\ 48 & 202,00 & 2,02 \\ 56 & 249,00 & 2,49 \\ 64 & 313,50 & 3,14 \\ 72 & 402,25 & 4,02 \\ 80 & 514,75 & 5,15 \\ 88 & 663,25 & 6,63 \\ 96 & 820,25 & 8,20 \\ 104 & 1003,00 & 10,03 \\ 112 & 1253,25 & 12,53 \\ 120 & 1516,50 & 15,17 \\ 128 & 1788,00 & 17,88 \\ 136 & 2092,00 & 20,92 \\ 144 & 2426,25 & 24,26 \\ 152 & 2805,50 & 28,06 \\ 160 & 3185,25 & 31,85 \\ 168 & 3584,50 & 35,85 \\ 176 & 4003,50 & 40,04 \\ 184 & 4442,75 & 44,43 \\ 166,2 & 4475,25 & 44,75 \\ 125,9 & 4473,00 & 44,73 \\ 49,1 & 4438,50 & 44,39 \\ 0 & 4352,25 & 43,52\end{array}$


ENSAIO - N4C1

Tensão ( $\mathrm{kPa}$ ) Leitura média do extensômetros Recalque ( $\mathrm{mm}$ )

$\begin{array}{crr}0 & 0,00 & 0,00 \\ 8 & 13,25 & 0,13 \\ 16 & 39,00 & 0,39 \\ 24 & 95,50 & 0,96 \\ 32 & 144,50 & 1,45 \\ 40 & 176,50 & 1,77 \\ 48 & 216,50 & 2,17 \\ 56 & 254,25 & 2,54 \\ 64 & 292,75 & 2,93 \\ 72 & 332,50 & 3,33 \\ 80 & 378,50 & 3,79 \\ 88 & 429,00 & 4,29 \\ 96 & 492,75 & 4,93 \\ 104 & 561,00 & 5,61 \\ 112 & 654,50 & 6,55 \\ 120 & 772,50 & 7,73 \\ 128 & 906,75 & 9,07 \\ 136 & 1074,25 & 10,74 \\ 144 & 1260,00 & 12,60 \\ 152 & 1476,75 & 14,77 \\ 160 & 1706,75 & 17,07 \\ 168 & 2001,00 & 20,01 \\ 176 & 2295,75 & 22,96 \\ 184 & 2612,50 & 26,13 \\ 192 & 2997,50 & 29,98 \\ 200 & 3338,75 & 33,39 \\ 208 & 3723,00 & 37,23 \\ 216 & 4145,25 & 41,45 \\ 224 & 4566,25 & 45,66 \\ 232 & 4938,75 & 49,39 \\ 216 & 4951,00 & 49,51 \\ 99,36 & 4862,00 & 48,62 \\ 0 & 4706,00 & 47,06\end{array}$


ENSAIO - N4C2

Tensão ( $\mathrm{kPa}$ ) Leitura média do extensômetros Recalque ( $\mathrm{mm}$ )

$\begin{array}{crr}0 & 0,00 & 0,00 \\ 12 & 99,25 & 0,99 \\ 24 & 230,50 & 2,31 \\ 36 & 343,00 & 3,43 \\ 48 & 416,25 & 4,16 \\ 60 & 477,25 & 4,77 \\ 72 & 533,25 & 5,33 \\ 84 & 601,25 & 6,01 \\ 96 & 674,75 & 6,75 \\ 108 & 745,75 & 7,46 \\ 120 & 831,00 & 8,31 \\ 132 & 934,50 & 9,35 \\ 144 & 1077,50 & 10,78 \\ 156 & 1281,75 & 12,82 \\ 168 & 1520,25 & 15,20 \\ 180 & 1803,50 & 18,04 \\ 192 & 2133,00 & 21,33 \\ 204 & 2466,00 & 24,66 \\ 216 & 2850,75 & 28,51 \\ 228 & 3230,50 & 32,31 \\ 240 & 3646,00 & 36,46 \\ 252 & 4094,50 & 40,95 \\ 264 & 4579,25 & 45,79 \\ 250,3 & 4606,00 & 46,06 \\ 118,7 & 4577,00 & 45,77 \\ 0 & 4350,00 & 43,50\end{array}$


ENSAIO - N6C1

Tensão ( $\mathrm{kPa}$ ) Leitura média do extensômetros Recalque ( $\mathrm{mm}$ )

$\begin{array}{crr}0 & 0,00 & 0,00 \\ 12 & 43,75 & 0,44 \\ 24 & 167,00 & 1,67 \\ 36 & 293,50 & 2,94 \\ 48 & 399,00 & 3,99 \\ 60 & 498,00 & 4,98 \\ 72 & 591,25 & 5,91 \\ 84 & 697,25 & 6,97 \\ 96 & 834,00 & 8,34 \\ 108 & 1004,75 & 10,05 \\ 120 & 1236,25 & 12,36 \\ 132 & 1488,75 & 14,89 \\ 144 & 1741,50 & 17,42 \\ 156 & 2050,25 & 20,50 \\ 168 & 2362,75 & 23,63 \\ 180 & 2695,75 & 26,96 \\ 192 & 3079,75 & 30,80 \\ 204 & 3464,50 & 34,65 \\ 216 & 3869,50 & 38,70 \\ 228 & 4273,50 & 42,74 \\ 240 & 4663,75 & 46,64 \\ 252 & 5052,00 & 50,52 \\ 238 & 5067,00 & 50,67 \\ 85 & 5006,50 & 50,07 \\ 0 & 4776,50 & 47,77\end{array}$


ENSAIO - N6C2

Tensão ( $\mathrm{kPa}$ ) Leitura média do extensômetros Recalque ( $\mathrm{mm}$ )

$\begin{array}{crr}0 & 0,00 & 0,00 \\ 12 & 37,25 & 0,37 \\ 24 & 82,50 & 0,83 \\ 36 & 165,50 & 1,66 \\ 48 & 239,00 & 2,39 \\ 60 & 305,50 & 3,06 \\ 72 & 370,50 & 3,71 \\ 84 & 436,50 & 4,37 \\ 96 & 508,50 & 5,09 \\ 108 & 597,00 & 5,97 \\ 120 & 686,00 & 6,86 \\ 132 & 791,00 & 7,91 \\ 144 & 897,00 & 8,97 \\ 156 & 1042,50 & 10,43 \\ 168 & 1206,25 & 12,06 \\ 180 & 1394,25 & 13,94 \\ 192 & 1628,75 & 16,29 \\ 204 & 1875,50 & 18,76 \\ 216 & 2145,75 & 21,46 \\ 228 & 2442,00 & 24,42 \\ 240 & 2767,00 & 27,67 \\ 252 & 3101,00 & 31,01 \\ 264 & 3476,75 & 34,77 \\ 276 & 3877,50 & 38,78 \\ 288 & 4292,75 & 42,93 \\ 300 & 4722,25 & 47,22 \\ 286 & 4758,00 & 47,58 \\ 138 & 4716,00 & 47,16\end{array}$


ENSAIO - N8C1

Tensão ( $\mathrm{kPa}$ ) Leitura média do extensômetros Recalque ( $\mathrm{mm}$ )

$\begin{array}{crr}0 & 0,00 & 0,00 \\ 18 & 42,75 & 0,43 \\ 36 & 108,25 & 1,08 \\ 54 & 173,00 & 1,73 \\ 72 & 232,50 & 2,33 \\ 90 & 295,00 & 2,95 \\ 108 & 352,50 & 3,53 \\ 126 & 415,25 & 4,15 \\ 144 & 480,00 & 4,80 \\ 162 & 548,25 & 5,48 \\ 180 & 621,75 & 6,22 \\ 198 & 707,25 & 7,07 \\ 216 & 808,00 & 8,08 \\ 234 & 913,50 & 9,14 \\ 252 & 1040,75 & 10,41 \\ 270 & 1186,25 & 11,86 \\ 288 & 1357,00 & 13,57 \\ 306 & 1547,00 & 15,47 \\ 324 & 1757,75 & 17,58 \\ 342 & 1991,50 & 19,92 \\ 360 & 2269,33 & 22,69 \\ 378 & 2494,00 & 24,94 \\ 396 & 2754,75 & 27,55 \\ 414 & 3026,25 & 30,26 \\ 432 & 3293,25 & 32,93 \\ 450 & 3577,50 & 35,78 \\ 430,5 & 3612,50 & 36,13 \\ 199,97 & 3531,00 & 35,31 \\ 171,8 & 3498,50 & 34,99 \\ 66,38 & 3313,50 & 33,14 \\ 0 & 3036,50 & 30,37 \\ & & \end{array}$


ENSAIO - N8C2

Tensão ( $\mathrm{kPa}$ ) Leitura média do extensômetros Recalque ( $\mathrm{mm}$ )

$\begin{array}{crr}0 & 0,00 & 0,00 \\ 22 & 86,25 & 0,86 \\ 44 & 171,50 & 1,72 \\ 66 & 258,00 & 2,58 \\ 88 & 355,00 & 3,55 \\ 110 & 448,75 & 4,49 \\ 132 & 549,00 & 5,49 \\ 154 & 634,25 & 6,34 \\ 176 & 730,75 & 7,31 \\ 198 & 857,75 & 8,58 \\ 220 & 1019,50 & 10,20 \\ 242 & 1208,75 & 12,09 \\ 264 & 1441,25 & 14,41 \\ 286 & 1705,75 & 17,06 \\ 308 & 2000,25 & 20,00 \\ 330 & 2319,00 & 23,19 \\ 352 & 2679,75 & 26,80 \\ 374 & 3059,00 & 30,59 \\ 396 & 3474,25 & 34,74 \\ 418 & 3903,50 & 39,04 \\ 440 & 4362,50 & 43,63 \\ 428,1 & 4390,00 & 43,90 \\ 306,59 & 4366,50 & 43,67 \\ 123,1 & 4236,25 & 42,36\end{array}$


ENSAIO - S4C3

Tensão ( $\mathrm{kPa}$ ) Leitura média do extensômetros Recalque ( mm )

$\begin{array}{crr}0 & 0,00 & 0,00 \\ 8 & 107,75 & 1,08 \\ 16 & 212,75 & 2,13 \\ 24 & 315,25 & 3,15 \\ 32 & 512,25 & 5,12 \\ 40 & 839,75 & 8,40 \\ 48 & 1360,25 & 13,60 \\ 56 & 2120,75 & 21,21 \\ 64 & 3168,00 & 31,68 \\ 72 & 4040,00 & 40,40 \\ 80 & 5254,00 & 52,54 \\ 88 & 6290,75 & 62,91 \\ 78,86 & 6337,75 & 63,38 \\ 54,72 & 6339,42 & 63,39 \\ 27,35 & 6324,00 & 63,24 \\ 0 & 6204,00 & 62,04\end{array}$


ENSAIO - S4C4

Tensão ( $\mathrm{kPa}$ ) Leitura média do extensômetros Recalque ( mm )

$\begin{array}{crr}0 & 0,00 & \\ 6 & 78,50 & 0,00 \\ 12 & 178,00 & 0,79 \\ 18 & 270,75 & 1,78 \\ 24 & 348,75 & 2,71 \\ 30 & 414,00 & 3,49 \\ 36 & 470,50 & 4,14 \\ 42 & 542,00 & 4,71 \\ 48 & 608,50 & 5,42 \\ 54 & 676,75 & 6,09 \\ 60 & 745,25 & 6,77 \\ 66 & 816,50 & 7,45 \\ 72 & 909,25 & 8,17 \\ 78 & 1022,25 & 9,09 \\ 84 & 1134,25 & 10,22 \\ 90 & 1275,25 & 11,34 \\ 96 & 1437,25 & 12,75 \\ 102 & 1659,00 & 14,37 \\ 108 & 1866,25 & 16,59 \\ 114 & 2087,75 & 18,66 \\ 120 & 2307,75 & 20,88 \\ 126 & 2524,00 & 23,08 \\ 132 & 2800,25 & 25,24 \\ 138 & 3070,25 & 28,00 \\ 144 & 3357,00 & 30,70 \\ 150 & 3656,50 & 33,57 \\ 156 & 3978,25 & 36,57 \\ 162 & 4285,00 & 39,78 \\ 168 & 4620,75 & 42,85 \\ 155,7 & 4646,50 & 46,21 \\ 74 & 4633,25 & 46,47 \\ 0 & 4398,00 & 46,33 \\ & & 43,98 \\ & & \end{array}$


ENSAIO - S6C3

Tensão ( $\mathrm{kPa}$ ) Leitura média do extensômetros Recalque ( mm )

$\begin{array}{rrr}0 & 0,00 & 0,00 \\ 6 & 14,75 & 0,15 \\ 12 & 32,00 & 0,32 \\ 18 & 44,00 & 0,44 \\ 24 & 66,50 & 0,67 \\ 30 & 110,50 & 1,11 \\ 36 & 176,00 & 1,76 \\ 42 & 226,50 & 2,27 \\ 48 & 269,25 & 2,69 \\ 54 & 320,75 & 3,21 \\ 60 & 372,25 & 3,72 \\ 66 & 435,50 & 4,36 \\ 72 & 509,50 & 5,10 \\ 78 & 602,25 & 6,02 \\ 84 & 706,75 & 7,07 \\ 90 & 833,75 & 8,34 \\ 96 & 982,75 & 9,83 \\ 102 & 1166,75 & 11,67 \\ 108 & 1345,25 & 13,45 \\ 114 & 1543,75 & 15,44 \\ 120 & 1752,50 & 17,53 \\ 126 & 1954,50 & 19,55 \\ 132 & 2181,50 & 21,82 \\ 138 & 2413,25 & 24,13 \\ 144 & 2644,00 & 26,44 \\ 150 & 2887,75 & 28,88 \\ 156 & 3132,75 & 31,33 \\ 162 & 3382,50 & 33,83 \\ 168 & 3630,50 & 36,31 \\ 174 & 3892,75 & 38,93 \\ 180 & 4144,75 & 41,45 \\ 186 & 4408,75 & 44,09 \\ 192 & 4671,50 & 46,72 \\ 178 & 4698 & 46,98 \\ 120,1 & 4689,25 & 46,89 \\ 44,7 & 46440 & 44,90 \\ 0 & 4489,5 & \end{array}$


ENSAIO - S6C4

Tensão ( $\mathrm{kPa}$ ) Leitura média do extensômetros Recalque ( $\mathrm{mm}$ )

$\begin{array}{crr}0 & 0,00 & 0,00 \\ 10 & 33,75 & 0,34 \\ 20 & 115,00 & 1,15 \\ 30 & 199,00 & 1,99 \\ 40 & 275,75 & 2,76 \\ 50 & 340,00 & 3,40 \\ 60 & 395,25 & 3,95 \\ 70 & 453,00 & 4,53 \\ 80 & 529,00 & 5,29 \\ 90 & 635,50 & 6,36 \\ 100 & 770,75 & 7,71 \\ 110 & 956,25 & 9,56 \\ 120 & 1177,00 & 11,77 \\ 130 & 1418,75 & 14,19 \\ 140 & 1691,50 & 16,92 \\ 150 & 2008,00 & 20,08 \\ 160 & 2342,50 & 23,43 \\ 170 & 2675,00 & 26,75 \\ 180 & 3050,75 & 30,51 \\ 190 & 3481,00 & 34,81 \\ 200 & 3944,75 & 39,45 \\ 210 & 4456,75 & 44,57 \\ 191,1 & 4493,50 & 44,94 \\ 118,3 & 4487,25 & 44,87 \\ 58,3 & 4456,00 & 44,56\end{array}$


ENSAIO - Q1

Tensão ( $\mathrm{kPa}$ ) Leitura média do extensômetros Recalque ( $\mathrm{mm}$ )

$\begin{array}{crr}0 & 0,00 & 0,00 \\ 5 & 0,00 & 0,00 \\ 11 & 61,75 & 0,62 \\ 17 & 210,25 & 2,10 \\ 23 & 226,75 & 2,27 \\ 29 & 281,75 & 2,82 \\ 35 & 335,50 & 3,36 \\ 41 & 412,00 & 4,12 \\ 47 & 504,00 & 5,04 \\ 53 & 604,75 & 6,05 \\ 59 & 730,25 & 7,30 \\ 65 & 916,25 & 9,16 \\ 71 & 1035,75 & 10,36 \\ 77 & 1291,75 & 12,92 \\ 83 & 1564,50 & 15,65 \\ 89 & 1814,75 & 18,15 \\ 95 & 2127,75 & 21,28 \\ 101 & 2448,00 & 24,48 \\ 107 & 2783,00 & 27,83 \\ 113 & 3176,70 & 31,77 \\ 119 & 3581,50 & 35,82 \\ 125 & 4025,25 & 40,25 \\ 131 & 4507,00 & 45,07 \\ 119,4 & 4548,50 & 45,49 \\ 72,2 & 4540,00 & 45,40 \\ 41,02 & 4520,75 & 45,21 \\ 21,72 & 4500,25 & 45,00 \\ 5 & 4482,25 & 44,82\end{array}$


ENSAIO - Q2

Tensão ( $\mathrm{kPa}$ ) Leitura média do extensômetros Recalque ( $\mathrm{mm}$ )

$\begin{array}{crr}0 & 0,00 & 0,00 \\ 5 & 0,00 & 0,00 \\ 15 & 47,00 & 0,47 \\ 25 & 100,00 & 1,00 \\ 35 & 144,00 & 1,44 \\ 45 & 189,00 & 1,89 \\ 55 & 231,00 & 2,31 \\ 65 & 284,00 & 2,84 \\ 75 & 357,00 & 3,57 \\ 85 & 495,00 & 4,95 \\ 95 & 714,00 & 7,14 \\ 105 & 1216,00 & 12,16 \\ 115 & 2020,00 & 20,20 \\ 125 & 2798,00 & 27,98 \\ 135 & 3567,00 & 35,67 \\ 145 & 4372,00 & 43,72 \\ 155 & 5238,00 & 52,38 \\ 141,2 & 5272,00 & 52,72 \\ 108,6 & 5272,00 & 52,72 \\ 56,8 & 5243,00 & 52,43 \\ 26 & 5211,00 & 52,11 \\ 0 & 5130,00 & 51,30\end{array}$


ENSAIO - QS1

Tensão ( $\mathrm{kPa}$ ) Leitura média do extensômetros Recalque ( $\mathrm{mm}$ )

$\begin{array}{crr}0 & 0,00 & 0,00 \\ 5 & 0,00 & 0,00 \\ 9 & 14,75 & 0,15 \\ 13 & 48,25 & 0,48 \\ 17 & 56,00 & 0,56 \\ 21 & 117,25 & 1,17 \\ 25 & 174,25 & 1,74 \\ 29 & 236,25 & 2,36 \\ 33 & 316,25 & 3,16 \\ 37 & 426,75 & 4,27 \\ 41 & 673,25 & 6,73 \\ 45 & 885,00 & 8,85 \\ 49 & 1112,00 & 11,12 \\ 53 & 1433,50 & 14,34 \\ 57 & 1768,25 & 17,68 \\ 61 & 2160,50 & 21,61 \\ 65 & 2596,50 & 25,97 \\ 69 & 2982,75 & 29,83 \\ 73 & 3418,25 & 34,18 \\ 77 & 3906,25 & 39,06 \\ 81 & 4339,50 & 43,40 \\ 43 & 4358,25 & 43,58 \\ 5 & 4301,75 & 43,02\end{array}$


ENSAIO - QS2

Tensão ( $\mathrm{kPa}$ ) Leitura média do extensômetros Recalque ( $\mathrm{mm}$ )

$\begin{array}{crr}0 & 0,00 & 0,00 \\ 5 & 0,00 & 0,00 \\ 9 & 24,00 & 0,24 \\ 13 & 49,75 & 0,50 \\ 17 & 78,75 & 0,79 \\ 21 & 117,00 & 1,17 \\ 25 & 173,50 & 1,74 \\ 29 & 243,50 & 2,44 \\ 33 & 318,75 & 3,19 \\ 37 & 428,75 & 4,29 \\ 41 & 551,00 & 5,51 \\ 45 & 729,75 & 7,30 \\ 49 & 963,25 & 9,63 \\ 53 & 1243,25 & 12,43 \\ 57 & 1574,50 & 15,75 \\ 61 & 1946,75 & 19,47 \\ 65 & 2378,25 & 23,78 \\ 69 & 2848,50 & 28,49 \\ 73 & 3365,25 & 33,65 \\ 77 & 4006,00 & 40,06 \\ 81 & 4643,00 & 46,43 \\ 85 & 5270,33 & 52,70 \\ 89 & 5948,67 & 59,49 \\ 93 & 6541,00 & 65,41 \\ 97 & 7185,67 & 71,86 \\ 81,4 & 7295,67 & 72,96 \\ 55,2 & 7209,00 & 72,09 \\ 52,8 & 7207,00 & 72,07 \\ 40 & 7200,67 & 72,01\end{array}$




\section{ANEXO E - Planilhas do teor de umidade.}

Local: $\quad$ Campo Experimental Fundações

Data: $\quad 24 / 06 / 00$

Ensaio: N1C3 Profundidade: $1,5 \mathrm{~m}$

\begin{tabular}{|l|c|c|c|}
\hline Determinação no & 1 & 2 & 3 \\
\hline cápsula no & $\mathrm{P} 151$ & $\mathrm{P} 11$ & $\mathrm{P} 18$ \\
solo + tara + água (g) & 16,94 & 18,53 & 20,75 \\
solo + tara (g) & 16,34 & 17,86 & 19,94 \\
tara (g) & 11,23 & 11,81 & 12,14 \\
água (g) & 0,59 & 0,67 & 0,82 \\
solo (g) & 5,11 & 6,05 & 7,80 \\
umidade (\%) & 11,64 & 11,07 & 10,45 \\
\hline umidade média (\%) & 11,06 & \multicolumn{3}{|l}{} \\
\hline
\end{tabular}

\begin{tabular}{|l|c|c|c|}
\hline Determinação no & 1 & 2 & 3 \\
\hline cápsula no & 235 & 24 & 156 \\
solo + tara + água (g) & 23,06 & 17,85 & 22,67 \\
solo + tara (g) & 22,19 & 16,86 & 21,76 \\
tara (g) & 15,65 & 9,31 & 14,50 \\
água (g) & 0,87 & 0,99 & 0,91 \\
solo (g) & 6,55 & 7,56 & 7,25 \\
umidade (\%) & 13,29 & 13,06 & 12,55 \\
\hline umidade média (\%) & 12,97 & \multicolumn{3}{|l}{} \\
\hline
\end{tabular}

\begin{tabular}{|l|c|c|c|}
\hline Determinação no & 1 & 2 & 3 \\
\hline cápsula no & 54 & 229 & $\mathrm{P} 146$ \\
solo + tara + água (g) & 17,49 & 19,42 & 18,71 \\
solo + tara (g) & 16,48 & 18,43 & 17,68 \\
tara (g) & 9,34 & 11,37 & 10,62 \\
água (g) & 1,00 & 0,99 & 1,03 \\
solo (g) & 7,15 & 7,06 & 7,06 \\
umidade (\%) & 14,05 & 14,03 & 14,64 \\
\hline umidade média (\%) & 14,24 & \multicolumn{2}{|l}{} \\
\hline
\end{tabular}

\begin{tabular}{|l|c|c|c|}
\hline Determinação no & 1 & 2 & 3 \\
\hline cápsula no & 208 & $\mathrm{P} 131$ & 202 \\
solo + tara + água (g) & 21,08 & 19,73 & 17,44 \\
solo + tara (g) & 20,09 & 18,70 & 16,69 \\
tara (g) & 13,01 & 11,35 & 11,26 \\
água (g) & 0,99 & 1,03 & 0,75 \\
solo (g) & 7,08 & 7,36 & 5,43 \\
Umidade (\%) & 14,00 & 13,96 & 13,88 \\
\hline Umidade média (\%) & 13,95 & \multicolumn{3}{|l}{} \\
\cline { 1 - 2 }
\end{tabular}


Local:

Campo Experimental Fundações

Data:

$11 / 05 / 00$

Ensaio:

$\mathrm{N} 4 \mathrm{C} 1$

Profundidade: $4,0 \mathrm{~m}$

\begin{tabular}{|l|c|c|c|}
\hline Determinação no & 1 & 2 & 3 \\
\hline cápsula no & $\mathrm{P} 3$ & $\mathrm{P} 123$ & $\mathrm{P} 20$ \\
solo + tara + água (g) & 15,22 & 15,00 & 17,91 \\
solo + tara (g) & 14,74 & 14,44 & 17,00 \\
tara (g) & 11,95 & 11,29 & 11,89 \\
água (g) & 0,48 & 0,56 & 0,91 \\
solo (g) & 2,79 & 3,15 & 5,11 \\
umidade (\%) & 17,20 & 17,78 & 17,81 \\
\hline umidade média (\%) & 17,60 & \multicolumn{3}{|l}{} \\
\cline { 1 - 2 }
\end{tabular}

\begin{tabular}{|l|c|c|c|}
\hline Determinação no & 1 & 2 & 3 \\
\hline cápsula no & $\mathrm{P} 137$ & $\mathrm{P} 48$ & $\mathrm{P} 168$ \\
solo + tara + água (g) & 18,78 & 17,66 & 20,43 \\
solo + tara (g) & 17,59 & 16,82 & 19,14 \\
tara (g) & 10,87 & 11,96 & 11,86 \\
água (g) & 1,19 & 0,84 & 1,29 \\
solo (g) & 6,72 & 4,86 & 7,28 \\
umidade (\%) & 17,71 & 17,28 & 17,72 \\
\hline umidade média (\%) & 17,57 & \multicolumn{3}{|l}{} \\
\hline
\end{tabular}

\begin{tabular}{|l|c|c|}
\hline Determinação $\mathbf{n} \mathbf{0}$ & 1 & 2 \\
\hline cápsula $\mathbf{n}$ - & 209 & 219 \\
solo + tara + água (g) & 18,86 & 18,62 \\
solo + tara (g) & 18,07 & 17,72 \\
tara (g) & 13,62 & 12,53 \\
água (g) & 0,79 & 0,90 \\
solo (g) & 4,45 & 5,19 \\
umidade (\%) & 17,75 & 17,34 \\
\hline umidade média (\%) & 17,55 & \\
\cline { 1 - 2 }
\end{tabular}

\begin{tabular}{|l|c|c|c|}
\hline Determinação $\mathbf{n}^{\mathbf{0}}$ & 1 & 2 & 3 \\
\hline cápsula no & $\mathrm{P} 80$ & $\mathrm{P} 62$ & 195 \\
solo + tara + água (g) & 16,05 & 17,22 & 17,31 \\
solo + tara (g) & 15,31 & 16,32 & 16,71 \\
tara (g) & 10,99 & 11,09 & 13,23 \\
água (g) & 0,74 & 0,90 & 0,60 \\
solo (g) & 4,32 & 5,23 & 3,48 \\
umidade (\%) & 17,13 & 17,21 & 17,24 \\
\hline umidade média (\%) & 17,19 & \multicolumn{3}{|l}{} \\
\hline
\end{tabular}


Local:

Campo Experimental Fundações

Data:

09/06/00

Ensaio:

$\mathrm{N} 4 \mathrm{C} 2$

Profundidade: $4,0 \mathrm{~m}$

\begin{tabular}{|l|c|c|c|}
\hline Determinação no & 1 & 2 & 3 \\
\hline cápsula no & $\mathrm{P} 117$ & $\mathrm{P} 153$ & $\mathrm{P} 120$ \\
solo + tara + água (g) & 15,33 & 19,12 & 17,09 \\
solo + tara (g) & 14,73 & 18,16 & 16,24 \\
tara (g) & 10,93 & 11,92 & 10,78 \\
água (g) & 0,60 & 0,96 & 0,85 \\
solo (g) & 3,80 & 6,23 & 5,47 \\
umidade (\%) & 15,68 & 15,42 & 15,49 \\
\hline umidade média (\%) & 15,53 & \multicolumn{3}{|l}{} \\
\cline { 1 - 2 }
\end{tabular}

\begin{tabular}{|l|c|c|c|}
\hline Determinação no & 1 & 2 & 3 \\
\hline cápsula no & $\mathrm{P} 97$ & 191 & $\mathrm{P} 66$ \\
solo + tara + água (g) & 18,93 & 21,46 & 17,81 \\
solo + tara (g) & 17,83 & 20,34 & 16,83 \\
tara (g) & 11,03 & 13,31 & 10,76 \\
água (g) & 1,10 & 1,12 & 0,97 \\
solo (g) & 6,79 & 7,03 & 6,07 \\
umidade (\%) & 16,21 & 15,96 & 16,04 \\
\hline umidade média (\%) & 16,07 & \multicolumn{3}{|l}{} \\
\hline
\end{tabular}

\begin{tabular}{|l|c|c|c|}
\hline Determinação no & 1 & 2 & 3 \\
\hline cápsula no & 200 & 204 & 190 \\
solo + tara + água (g) & 20,99 & 21,13 & 23,43 \\
solo + tara (g) & 19,94 & 20,04 & 22,01 \\
tara (g) & 13,47 & 13,31 & 13,20 \\
água (g) & 1,05 & 1,09 & 1,42 \\
solo (g) & 6,47 & 6,73 & 8,81 \\
umidade (\%) & 16,23 & 16,24 & 16,12 \\
\hline umidade média (\%) & 16,20 & \multicolumn{3}{|l}{} \\
\hline
\end{tabular}

\begin{tabular}{|l|c|c|c|}
\hline Determinação $\mathbf{n}^{\mathbf{0}}$ & 1 & 2 & 3 \\
\hline cápsula no & 196 & $\mathrm{P} 108$ & 217 \\
solo + tara + água (g) & 21,65 & 18,92 & 19,08 \\
solo + tara (g) & 20,42 & 17,74 & 18,21 \\
tara (g) & 12,90 & 10,50 & 12,96 \\
água (g) & 1,23 & 1,18 & 0,87 \\
solo (g) & 7,52 & 7,24 & 5,25 \\
umidade (\%) & 16,34 & 16,24 & 16,53 \\
\hline umidade média (\%) & 16,37 & \multicolumn{3}{|l}{} \\
\hline
\end{tabular}


Local:

Campo Experimental Fundações

Data:

20/05/00

Ensaio:

$\mathrm{N} 6 \mathrm{C} 1$

Profundidade: $6,0 \mathrm{~m}$

\begin{tabular}{|l|c|c|c|}
\hline Determinação no & 1 & 2 & 3 \\
\hline cápsula no & 250,00 & $\mathrm{P} 82$ & $\mathrm{P} 144$ \\
solo + tara + água (g) & 25,04 & 24,97 & 19,90 \\
solo + tara (g) & 23,19 & 22,59 & 18,55 \\
tara (g) & 12,62 & 10,03 & 11,13 \\
água (g) & 1,85 & 2,38 & 1,35 \\
solo (g) & 10,57 & 12,56 & 7,42 \\
umidade (\%) & 17,50 & 18,95 & 18,19 \\
\hline umidade média (\%) & 18,22 & \multicolumn{3}{|l}{} \\
\cline { 1 - 2 }
\end{tabular}

\begin{tabular}{|l|c|c|c|}
\hline Determinação no & 1 & 2 & 3 \\
\hline cápsula no & $\mathrm{P} 102$ & $\mathrm{P} 28$ & $\mathrm{P} 98$ \\
solo + tara + água (g) & 15,60 & 17,80 & 19,71 \\
solo + tara (g) & 14,92 & 16,77 & 18,23 \\
tara (g) & 11,32 & 11,30 & 10,48 \\
água (g) & 0,68 & 1,03 & 1,48 \\
solo (g) & 3,60 & 5,47 & 7,75 \\
umidade (\%) & 18,89 & 18,83 & 19,10 \\
\hline umidade média (\%) & 18,94 & \multicolumn{3}{|l}{} \\
\cline { 1 - 3 }
\end{tabular}

\begin{tabular}{|l|c|c|c|}
\hline Determinação no & 1 & 2 & 3 \\
\hline cápsula $\mathbf{n}$ - & $\mathrm{P} 87$ & 242 & $\mathrm{P} 77$ \\
solo + tara + água (g) & 16,08 & 18,36 & 16,00 \\
solo + tara (g) & 15,29 & 17,27 & 15,18 \\
tara (g) & 11,16 & 11,44 & 10,83 \\
água (g) & 0,79 & 1,09 & 0,82 \\
solo (g) & 4,13 & 5,83 & 4,35 \\
umidade (\%) & 19,13 & 18,70 & 18,85 \\
\hline umidade média (\%) & 18,89 & \multicolumn{3}{|l}{} \\
\cline { 1 - 3 }
\end{tabular}

\begin{tabular}{|l|c|c|}
\hline Determinação $\mathbf{n}$ - & 1 & 2 \\
\hline cápsula no & $\mathrm{P} 133$ & $\mathrm{P} 49$ \\
solo + tara + água (g) & 15,27 & 18,94 \\
solo + tara (g) & 14,57 & 17,90 \\
tara (g) & 10,75 & 12,14 \\
água (g) & 0,70 & 1,04 \\
solo (g) & 3,82 & 5,76 \\
umidade (\%) & 18,32 & 18,06 \\
\hline umidade média (\%) & 18,19 & \\
\cline { 1 - 1 }
\end{tabular}


Local:

Campo Experimental Fundações

Data:

$15 / 06 / 00$

Ensaio:

$\mathrm{N} 6 \mathrm{C} 2$

Profundidade: $6,0 \mathrm{~m}$

\begin{tabular}{|l|c|c|}
\hline Determinação no & 1 & 2 \\
\hline cápsula no & 196 & 191 \\
solo + tara + água (g) & 22,67 & 19,11 \\
solo + tara (g) & 21,20 & 18,26 \\
tara (g) & 12,90 & 13,31 \\
água (g) & 1,47 & 0,85 \\
solo (g) & 8,30 & 4,95 \\
umidade (\%) & 17,66 & 17,25 \\
\hline umidade média (\%) & 17,45 & \\
\cline { 1 - 1 }
\end{tabular}

\begin{tabular}{|l|c|c|c|}
\hline Determinação no & 1 & 2 & 3 \\
\hline cápsula no & $\mathrm{P} 153$ & 217 & $\mathrm{P} 117$ \\
solo + tara + água (g) & 18,75 & 22,96 & 19,63 \\
solo + tara (g) & 17,69 & 21,40 & 18,29 \\
tara (g) & 11,92 & 12,96 & 10,93 \\
água (g) & 1,06 & 1,56 & 1,34 \\
solo (g) & 5,77 & 8,44 & 7,36 \\
umidade (\%) & 18,44 & 18,51 & 18,18 \\
\hline umidade média (\%) & 18,38 & \multicolumn{3}{|l}{} \\
\hline
\end{tabular}

\begin{tabular}{|l|c|c|c|}
\hline Determinação no & 1 & 2 & 3 \\
\hline cápsula no & 204 & 190 & $\mathrm{P} 66$ \\
solo + tara + água (g) & 20,56 & 20,26 & 16,48 \\
solo + tara (g) & 19,41 & 19,16 & 15,62 \\
tara (g) & 13,31 & 13,20 & 10,76 \\
água (g) & 1,16 & 1,10 & 0,86 \\
solo (g) & 6,10 & 5,96 & 4,86 \\
umidade (\%) & 18,96 & 18,45 & 17,68 \\
\hline umidade média (\%) & 18,36 & \multicolumn{3}{|l}{} \\
\hline
\end{tabular}

\begin{tabular}{|l|c|c|c|}
\hline Determinação no & 1 & 2 & 3 \\
\hline cápsula no & $\mathrm{P} 97$ & 210 & $\mathrm{P} 108$ \\
solo + tara + água (g) & 18,04 & 22,20 & 16,76 \\
solo + tara (g) & 16,92 & 20,81 & 15,77 \\
tara (g) & 11,03 & 13,48 & 10,50 \\
água (g) & 1,11 & 1,39 & 0,99 \\
solo (g) & 5,89 & 7,33 & 5,27 \\
umidade (\%) & 18,91 & 18,90 & 18,82 \\
\hline umidade média (\%) & 18,87 & \multicolumn{3}{|l}{} \\
\hline
\end{tabular}


Local:

Campo Experimental Fundações

Data:

25/05/00

Ensaio:

Profundidade: $8,0 \mathrm{~m}$

\begin{tabular}{|l|c|c|c|}
\hline Determinação no & 1 & 2 & 3 \\
\hline cápsula no & 196 & 217 & $\mathrm{P} 153$ \\
solo + tara + água (g) & 22,41 & 20,47 & 20,68 \\
solo + tara (g) & 20,94 & 19,32 & 19,33 \\
tara (g) & 12,91 & 12,96 & 11,92 \\
água (g) & 1,47 & 1,15 & 1,35 \\
solo (g) & 8,03 & 6,36 & 7,41 \\
umidade (\%) & 18,31 & 18,08 & 18,22 \\
\hline umidade média (\%) & 18,20 & \multicolumn{3}{|l}{} \\
\cline { 1 - 2 }
\end{tabular}

\begin{tabular}{|l|c|c|c|}
\hline Determinação no & 1 & 2 & 3 \\
\hline cápsula no & 204 & $\mathrm{P} 66$ & $\mathrm{P} 120$ \\
solo + tara + água (g) & 21,54 & 21,07 & 19,77 \\
solo + tara (g) & 20,29 & 19,52 & 18,40 \\
tara (g) & 13,32 & 10,76 & 10,78 \\
água (g) & 1,25 & 1,55 & 1,37 \\
solo (g) & 6,97 & 8,76 & 7,62 \\
umidade (\%) & 17,93 & 17,69 & 17,98 \\
\hline umidade média (\%) & 17,87 & \multicolumn{3}{|l}{} \\
\hline
\end{tabular}

\begin{tabular}{|l|c|c|c|}
\hline Determinação no & 1 & 2 & 3 \\
\hline cápsula no & $\mathrm{P} 117$ & $\mathrm{P} 97$ & 191 \\
solo + tara + água (g) & 20,96 & 20,95 & 20,63 \\
solo + tara (g) & 19,39 & 19,42 & 19,49 \\
tara (g) & 10,94 & 11,03 & 13,31 \\
água (g) & 1,57 & 1,53 & 1,14 \\
solo (g) & 8,45 & 8,39 & 6,18 \\
umidade (\%) & 18,58 & 18,24 & 18,45 \\
\hline umidade média (\%) & 18,42 & \multicolumn{3}{|l}{} \\
\cline { 1 - 3 }
\end{tabular}

\begin{tabular}{|l|c|c|c|}
\hline Determinação $\mathbf{n}$ - & 1 & 2 & 3 \\
\hline cápsula no & 245 & 210 & $\mathrm{P} 121$ \\
solo + tara + água (g) & 26,27 & 30,43 & 21,29 \\
solo + tara (g) & 24,20 & 27,64 & 19,54 \\
tara (g) & 13,66 & 13,48 & 10,62 \\
água (g) & 2,07 & 2,79 & 1,75 \\
solo (g) & 10,54 & 14,16 & 8,92 \\
umidade (\%) & 19,64 & 19,71 & 19,62 \\
\hline umidade média (\%) & 19,65 & \multicolumn{3}{|l}{} \\
\hline
\end{tabular}


Local:

Campo Experimental Fundações

Data:

20/06/00

Ensaio:

$\mathrm{N} 8 \mathrm{C} 2$

Profundidade: $8,0 \mathrm{~m}$

\begin{tabular}{|l|c|c|c|}
\hline Determinação no & 1 & 2 & 3 \\
\hline cápsula no & $\mathrm{P} 100$ & 202 & $\mathrm{P} 86$ \\
solo + tara + água (g) & 20,46 & 22,26 & 17,70 \\
solo + tara (g) & 19,07 & 20,67 & 16,67 \\
tara (g) & 10,84 & 11,26 & 10,60 \\
água (g) & 1,40 & 1,59 & 1,03 \\
solo (g) & 8,23 & 9,41 & 6,07 \\
umidade (\%) & 16,97 & 16,93 & 16,96 \\
\hline umidade média (\%) & 16,95 & \multicolumn{2}{|l}{} \\
\cline { 1 - 2 }
\end{tabular}

\begin{tabular}{|l|c|c|c|}
\hline Determinação no & 1 & 2 & 3 \\
\hline cápsula no & 190 & $\mathrm{P} 66$ & 204 \\
solo + tara + água (g) & 22,25 & 18,63 & 23,53 \\
solo + tara (g) & 20,90 & 17,47 & 22,04 \\
tara (g) & 13,20 & 10,76 & 13,31 \\
água (g) & 1,35 & 1,16 & 1,49 \\
solo (g) & 7,70 & 6,71 & 8,73 \\
umidade (\%) & 17,53 & 17,33 & 17,01 \\
\hline umidade média (\%) & 17,29 & \multicolumn{3}{|l}{} \\
\hline
\end{tabular}

\begin{tabular}{|l|c|c|c|}
\hline Determinação $\mathbf{n}^{\mathbf{0}}$ & 1 & 2 & 3 \\
\hline cápsula no & 191 & 210 & $\mathrm{P} 108$ \\
solo + tara + água (g) & 21,88 & 20,48 & 21,99 \\
solo + tara (g) & 20,58 & 19,42 & 20,26 \\
tara (g) & 13,31 & 13,48 & 10,50 \\
água (g) & 1,30 & 1,06 & 1,73 \\
solo (g) & 7,27 & 5,94 & 9,76 \\
umidade (\%) & 17,86 & 17,79 & 17,68 \\
\hline umidade média (\%) & 17,78 & \multicolumn{3}{|l}{} \\
\hline
\end{tabular}

\begin{tabular}{|l|c|c|c|}
\hline Determinação $\mathbf{n}^{\mathbf{0}}$ & 1 & 2 & 3 \\
\hline cápsula no & $\mathrm{P} 97$ & 217 & 196 \\
solo + tara + água (g) & 18,00 & 24,31 & 22,63 \\
solo + tara (g) & 16,92 & 22,57 & 21,18 \\
tara (g) & 11,03 & 12,96 & 12,90 \\
água (g) & 1,08 & 1,74 & 1,45 \\
solo (g) & 5,89 & 9,61 & 8,28 \\
umidade (\%) & 18,37 & 18,13 & 17,54 \\
\hline umidade média (\%) & 18,01 & \multicolumn{3}{|l}{} \\
\hline
\end{tabular}




\section{ANEXO F - Regressão múltipla linear para o critério de ruptura de $25 \mathrm{~mm}$.}

\begin{tabular}{|c|c|c|c|c|c|c|c|c|c|c|}
\hline & $\begin{array}{c}\sigma_{25} \\
(\mathrm{kPa})\end{array}$ & $\begin{array}{c}\text { sucção } \\
\text { (kPa) }\end{array}$ & $\begin{array}{l}\text { Prof. } \\
\text { (m) }\end{array}$ & & & & & & & \\
\hline & $\mathrm{y}$ & $\mathrm{x}$ & z & $x^{2}$ & $X . Z$ & x.y & $z^{2}$ & Z.y & & y (cor.) \\
\hline & 126,0 & 0,0 & 4,0 & 0,0 & 0,0 & 0,0 & 16,0 & 504,0 & & 117,22 \\
\hline & 181,0 & 18,0 & 4,0 & 324,0 & 72,0 & 3258,0 & 16,0 & 724,0 & & 169,12 \\
\hline & 205,0 & 28,0 & 4,0 & 784,0 & 112,0 & 5740,0 & 16,0 & 820,0 & & 197,96 \\
\hline & 165,0 & 0,0 & 6,0 & 0,0 & 0,0 & 0,0 & 36,0 & 990,0 & & 161,16 \\
\hline & 141,0 & 0,0 & 6,0 & 0,0 & 0,0 & 0,0 & 36,0 & 846,0 & & 161,16 \\
\hline & 174,0 & 12,0 & 6,0 & 144,0 & 72,0 & 2088,0 & 36,0 & 1044,0 & & 195,76 \\
\hline & 230,0 & 16,0 & 6,0 & 256,0 & 96,0 & 3680,0 & 36,0 & 1380,0 & & 207,30 \\
\hline & 64,0 & 0,0 & 1,5 & 0,0 & 0,0 & 0,0 & 2,3 & 96,0 & & 62,29 \\
\hline & 67,0 & 0,0 & 1,5 & 0,0 & 0,0 & 0,0 & 2,3 & 100,5 & & 62,29 \\
\hline & 102,0 & 15,0 & 1,5 & 225,0 & 22,5 & 1530,0 & 2,3 & 153,0 & & 105,55 \\
\hline & 122,0 & 22,0 & 1,5 & 484,0 & 33,0 & 2684,0 & 2,3 & 183,0 & & 125,73 \\
\hline & 146,0 & 33,0 & 1,5 & 1089,0 & 49,5 & 4818,0 & 2,3 & 219,0 & & 157,45 \\
\hline \multirow[t]{6}{*}{$\Sigma=$} & 1723,0 & 144,0 & 43,5 & 3306,0 & 457,0 & 23798,0 & 203,3 & 7059,5 & & \\
\hline & & & 3306,0 & 457,0 & 144,0 & & 23798,0 & & $A=$ & 2,88 \\
\hline & & & 457,0 & 203,3 & 43,5 & & 7059,5 & & $B=$ & 21,97 \\
\hline & & & 144,0 & 43,5 & 12,0 & & 1723,0 & & $C=$ & 29,34 \\
\hline & & & & & & & & & $\mathrm{R}=$ & 0,97 \\
\hline & & & & & & & & & $\mathrm{R}^{2}=$ & 0,94 \\
\hline
\end{tabular}




\section{ANEXO G - Regressão múltipla linear para o critério de ruptura de Pacheco Silva (1970).}

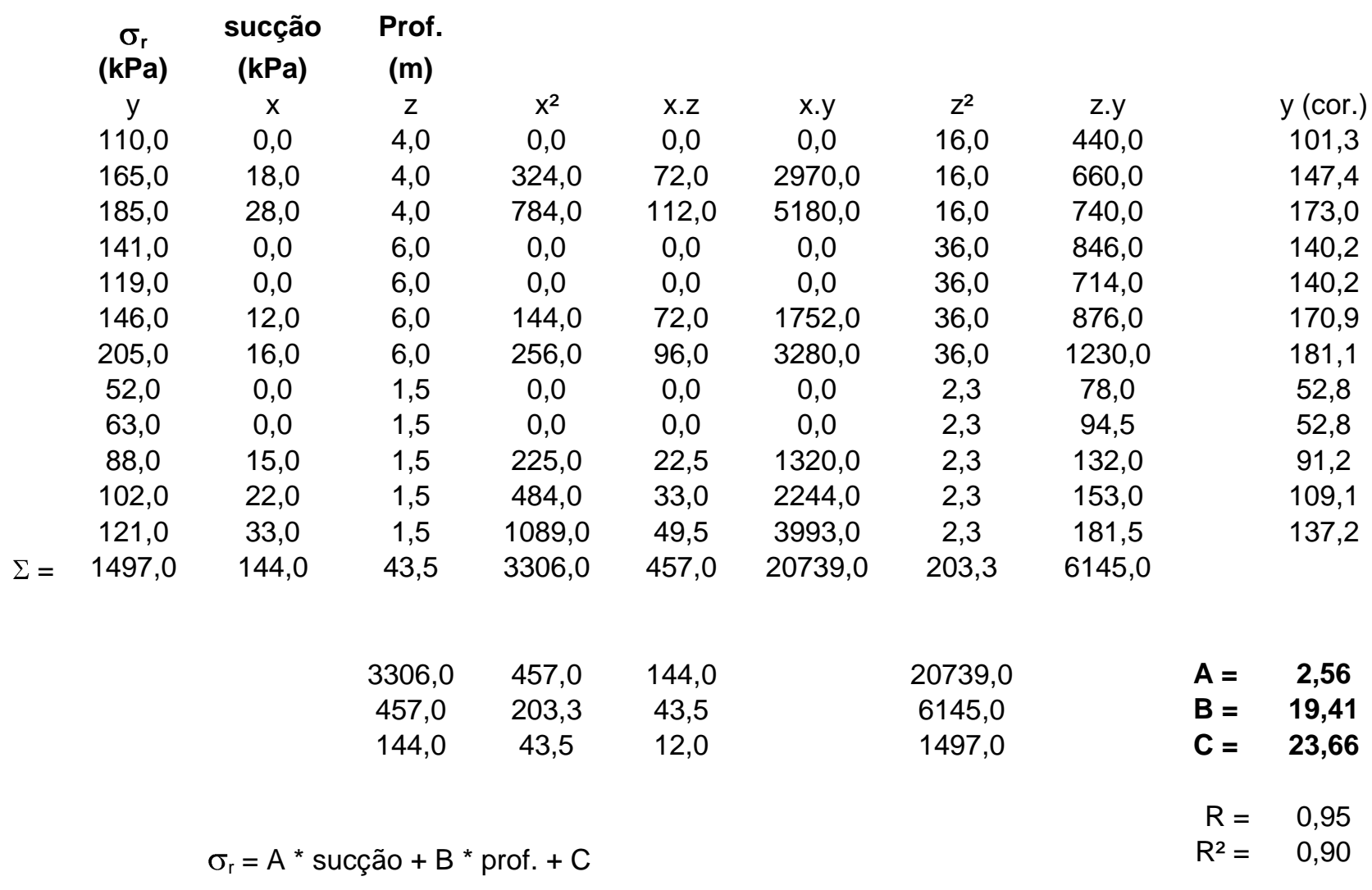

